Resíduos de Equipamentos Eletroeletrônicos: O Antropoceno Bate à Nossa Porta

\author{
Afonso, J. C.*
}

Rev. Virtual Quim., 2018, 10 (6), 1849-1897. Data de publicação na Web: 23 de novembro de 2018

http://rvq.sbq.org.br

\title{
Waste Electrical and Electronic Equipment: The Anthropocene Knocks on Our Door
}

Abstract: This review describes the technological, environmental, socio-cultural, economical and health challenges due to the waste electrical and electronic equipment. The rate of production of this waste has reached scary levels in the last years, and the level of perception of the populations facing the challenges imposed for their management greatly varies from one country to another. Solutions for waste electrical and electronic equipment are extremely complex, from the establishment of an effective reverse logistics of used products and reverse manufacturing protocols, to the proposal of technologies capable of processing the components of the various electrical and electronic products. Printed circuit boards, cathode ray tubes and liquid crystal displays are the most difficult components to recycle due to their multi-component nature: although they contain high-added value elements in much larger amounts than those of primary sources, they also present metallic components and organic compounds that are highly toxic to health and lead to environmental impacts. Brazil has begun to pay attention to the problem of e-waste relatively recently. Despite ongoing initiatives, the country still has a long way to go until the establishment of a management system that covers all its stages and peculiarities, such as its territorial extension. Waste electrical and electronic equipment is one of the most eloquent symbols of Anthropocene.

Keywords: WEEE; environmental impacts; health risks; reverse logistics; recycling; sustainable management.

\section{Resumo}

Esta revisão descreve a dimensão do problema que representam os resíduos de equipamentos eletroeletrônicos em termos tecnológicos, ambientais, socioculturais, econômicos e de saúde humana. Nos últimos anos a velocidade de produção desse tipo de lixo atingiu patamares assustadores, e o nível de percepção das populações frente aos desafios impostos para a sua gestão varia grandemente de um país para outro. As soluções para os resíduos eletroeletrônicos são extremamente complexas, desde o estabelecimento de uma logística reversa eficaz de produtos usados e de protocolos de manufatura reversa, até a proposta de tecnologias capazes de processar os componentes dos diversos produtos eletroeletrônicos. As placas de circuito impresso, os tubos de raios catódicos e as telas de cristal líquido são os componentes de reciclagem mais difícil devido à natureza multicomponente dos mesmos: se por um lado contêm elementos de alto valor agregado em quantidades muito superiores àquelas de fontes primárias, também apresentam componentes metálicos e compostos orgânicos altamente tóxicos à saúde e causadores de impactos ambientais. O Brasil começou a dar atenção ao problema dos resíduos eletroeletrônicos há relativamente pouco tempo. A despeito de iniciativas em curso, o país ainda tem um longo caminho a percorrer até o estabelecimento de um sistema de gestão que contemple todas as suas etapas e peculiaridades como a sua extensão territorial. Os resíduos de equipamentos eletroeletrônicos são um dos símbolos mais eloquentes do Antropoceno.

Palavras-chave: REEE; impactos ambientais; riscos à saúde; logística reversa; reciclagem; gestão sustentável.

\footnotetext{
* Universidade Federal do Rio de Janeiro, Instituto de Química, Departamento de Química Analítica, Cidade Universitária, CEP 29141-909, Rio de Janeiro-RJ, Brasil.

Mjulio@iq.ufri.br

DOI: $\underline{10.21577 / 1984-6835.20180121}$
} 


\section{Resíduos de Equipamentos Eletroeletrônicos: O Antropoceno Bate à Nossa Porta Júlio Carlos Afonso*}

Universidade Federal do Rio de Janeiro, Instituto de Química, Departamento de Química Analítica. Av. Athos da Silveira Ramos, 149, Bloco A, Sala 517, Cidade Universitária, CEP 29141909, Rio de Janeiro-RJ, Brasil

*julio@iq.ufri.br

Recebido em 30 de outubro de 2018. Aceito para publicação em 30 de outubro de 2018

1. Introdução

2. Resíduos Eletroeletrônicos (REE) em Resíduos Sólidos Urbanos (RSU)

3. Impactos Ambientais dos Resíduos Eletroeletrônicos (REE)

4. Riscos à Saúde Decorrentes do Manejo Incorreto dos Resíduos Eletroeletrônicos (REE)

5. Logística Reversa e Fluxo de Equipamentos Eletroeletrônicos (EEE) Usados

5.1. Experiências pelo mundo

5.2. Situação do Brasil

6. Manufatura Reversa dos Equipamentos Eletroeletrônicos

6.1. Generalidades

6.2. Componentes obtidos após a manufatura reversa

6.3. Sobras da manufatura reversa

6.4. A manufatura reversa no Brasil

7. Processamento de Componentes dos Equipamentos Eletroeletrônicos

7.1. Introdução

7.2. Placas de circuito impresso

7.3. Tubos de raios catódicos

7.4. Telas de LCD

8. P \& D no Brasil para Processamento de Equipamentos Eletroeletrônicos

9. Concepção de Futuras Gerações de Equipamentos Eletroeletrônicos

10. Conclusões 


\section{Introdução}

Por definição, resíduos de equipamentos eletroeletrônicos (REEE) ou simplesmente resíduos eletroeletrônicos (REE), ou ainda lixo eletroeletrônico (e-waste ou WEEE), são equipamentos que possuem em suas partes internas componentes elétricos e eletrônicos responsáveis pelo funcionamento dos mesmos, e que por razões de obsolescência (perceptiva ou programada) e impossibilidade de conserto são descartadas pelos seus consumidores. Os exemplos mais comuns evocados são os produtos de informática, telefonia e televisores, mas equipamentos médicos, eletrodomésticos, brinquedos, sistemas de alarme, automação e controle estão incluídos no rol do REE.

O ser humano desempenha um papel essencial na criação dos sistemas tecnológicos do cotidiano. A tecnologia em larga escala - a "tecnosfera" -, que atinge o planeta em escala global, é um fenômeno sociocultural moderno. ${ }^{1}$ A tecnosfera engloba todos os objetos tecnológicos produzidos pelo ser humano, como os equipamentos elétricos e eletrônicos (EEE). Contudo, a tecnosfera é um sistema e não apenas uma coleção de equipamentos tecnológicos. Ela engloba também os seres humanos e os sistemas profissionais e sociais por meio dos quais interagem com as tecnologias que desenvolveram, por exemplo: unidades fabris, escolas, universidades, organizações sindicais e bancos. ${ }^{2,3} \mathrm{~A}$ Internet é um exemplo muito representativo. $^{2}$

Com os avanços no mundo eletrônico ocorrendo quase diariamente e o aumento da disponibilidade de produtos para o público, a produção de EEE tem sido um dos setores de crescimento mais rápido, tanto nos países industrializados quanto naqueles em desenvolvimento. Ao mesmo tempo, a vida útil média dos produtos eletroeletrônicos foi drasticamente reduzida devido ao rápido aumento na demanda de produtos avançados. ${ }^{4,5}$ Os consumidores, movidos pelo poder e sedução de possuírem "a última palavra em tecnologia" de um determinado
$\mathrm{EEE}$, tendem a trocá-lo constantemente, mesmo quando o produto em uso ainda é plenamente funcional. A tecnosfera da comunicação e do conforto da vida diária gera gigantescas quantidades de REEE. ${ }^{2}$ Consequentemente, não é surpreendente ver um aumento impressionante da produção desses resíduos nas últimas décadas. ${ }^{6-9} \mathrm{~A}$ produção global aumenta a uma velocidade alarmante de 20 a 25 milhões de toneladas por ano, ${ }^{9,10}$ com uma taxa de crescimento estimada de $3 \%$ a $5 \%$ ao ano. ${ }^{11-13}$ De acordo com a organização Solving the e-Waste Problem Initiative, a quantidade de REEE produzida deve saltar para 65,4 milhões de toneladas por volta de 2017. ${ }^{14}$

O problema dos resíduos eletroeletrônicos é global, atingindo a todos os países mesmo que em diferentes proporções e pontos de vista. De acordo com a União Europeia (UE), a produção de REEE nos últimos seis anos é quatro vezes maior do que a dos resíduos sólidos urbanos (RSU). ${ }^{15}$ Na Austrália, ${ }^{16}$ a taxa de geração dos REEE é três vezes maior que a dos RSU. Esse resíduo já alcança $8 \%$ do lixo municipal nos EUA. Nos mercados emergentes a taxa de geração aumenta muito mais que nos países desenvolvidos. ${ }^{17} \mathrm{O}$ Brasil é o segundo maior gerador de REEE dentre os países em desenvolvimento e emergentes. ${ }^{18}$

As incríveis taxas de descarte anuais de REEE, em escala crescente, a partir de um passado relativamente recente inserem os REEE dentro do contexto da chamada "Grande aceleração" na qual, ${ }^{19,20}$ especialmente a partir da década de 1950 , se observa um acúmulo ambiental de resíduos de origem artificial ou antrópica (plásticos, resíduos de construção civil, fibras, artefatos de alumínio, rejeitos de atividades de mineração etc.). 0 Papa Francisco, em sua encíclica Laudato Sí, ${ }^{21}$ embasado por visões da ciência, filosofia, teologia e sociologia, destaca a sociedade de consumo e do descartável, que provoca uma geração incessante de resíduos e a exploração à exaustão de recursos naturais (água, solos, minérios e biodiversidade), também marcas da "Grande Aceleração". .9,20

Os REEE trazem duas implicações que justificam sua inserção no rol das 
preocupações da Organização das Nações Unidas (ONU): ${ }^{22}$ o volume crescente de vendas, especialmente em países não desenvolvidos, e a presença de até mais de mil substâncias diferentes, muitas das quais são de alto valor agregado ou altamente tóxicas. ${ }^{23-}$ ${ }^{25} \mathrm{~A}$ rápida obsolescência dos EEE faz com que a cadeia linear de produção de extraçãoutilização-descarte seja ainda mais intensiva em recursos, aumentando, portanto, seus impactos sobre o meio ambiente, a saúde humana e a economia. ${ }^{25}$

Este trabalho apresenta uma revisão minuciosa sobre o tema resíduos eletroeletrônicos abordando não somente aspectos técnicos (da concepção à reciclagem), mas também incorporando aspectos ambientais, socioculturais, econômicos e de saúde humana. Ao longo do texto, ficará evidenciado o porquê desses resíduos representarem uma das faces mais visíveis de uma nova época geológica - o Antropoceno ${ }^{19,26,27}$ - na qual o ser humano se converteu em uma força geológica, capaz de mudar o planeta tanto ou mais que as forças naturais. $^{28}$

\section{Resíduos Eletroeletrônicos (REE) em Resíduos Sólidos Urbanos (RSU)}

É costume imaginar o resíduo eletroeletrônico como um todo, quando na verdade ele é composto por inúmeras partes. Essa visão simplória da questão acarreta como um de seus desdobramentos o descarte dos EEE como um lixo qualquer junto aos resíduos sólidos urbanos (RSU), sem atentar para as consequências ambientais dessa atitude. Mesmo se o produto eletroeletrônico é descartado por inteiro, o impacto deste no meio ambiente ocorrerá devido à presença em muitos de seus componentes de metais tóxicos e compostos orgânicos, particularmente os retardantes de chama bromados. A quantidade e a variedade de componentes tóxicos e preciosos em EEE superam em qualquer escala aquelas existentes nos RSU habituais. ${ }^{15,17} \mathrm{O}$ descarte de resíduos de composição distinta daqueles de origem natural configura uma marca do Antropoceno. ${ }^{26,29}$

Ao se descartar EEE em aterros (sanitários ou controlados), e pior ainda em lixões ou terrenos baldios (Figura 1), o que ocorre é dispersar um recurso não renovável raro (índio, ouro, paládio etc.) em uma massa de resíduos muito maior do que o próprio volume de EEE, levando à perda da possibilidade de reciclagem dos componentes diretamente separáveis desses produtos. ${ }^{12,22}$ Mesmo elementos mais familiares como fósforo, cobre e alumínio estão seguindo esse caminho a uma taxa alarmante. ${ }^{30}$ Portanto, não dar a esses resíduos a devida atenção não é só danoso ao meio ambiente, mas também se caracteriza como um desperdício econômico. ${ }^{31}$

Mais de $70 \%$ dos metais de EEE se distribuem em frações de pequeno tamanho após moagem e processamento do lixo. ${ }^{32} \mathrm{Um}$ estudo da distribuição de metais-traço presentes em RSU submetidos à queima indicou que a fração metálica rica em cobre contém metais preciosos como paládio, prata e ouro, e a fração rica em ferro concentra a maioria dos elementos que formam ligas com ele. A platina se distribui entre ambas as fases. ${ }^{33} \mathrm{~A}$ maior parte dos metais preciosos em aterros sanitários provém de EEE descartados junto com os RSU. ${ }^{32,33}$ A acessibilidade de mercados com menor poder aquisitivo aumentará ainda mais a inserção e a geração de EEE no mundo nos anos que se seguirão, ${ }^{34}$ enquanto que a infraestrutura urbana de serviços e a conscientização da população não acompanharão essa velocidade de inserção dos EEE. ${ }^{33,34}$ 


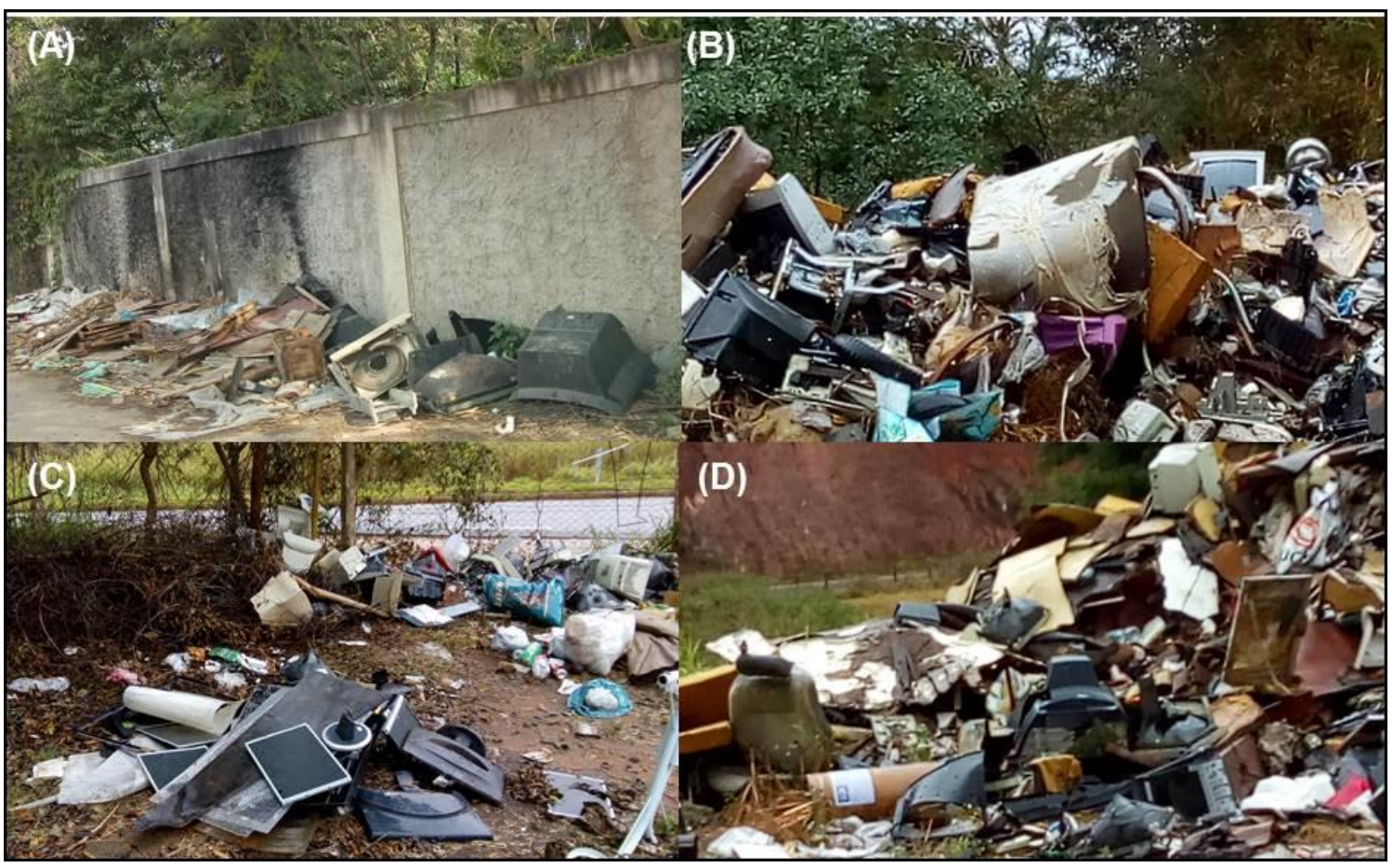

Figura 1: Resíduos eletroeletrônicos descartados em meio a outros resíduos em terreno baldio (A), área de proteção ambiental (B), depósito clandestino (C) e propriedade rural (D)

Os resíduos eletroeletrônicos dispostos em aterros municipais não são abordados em profundidade nas leis ambientais sobre o tema. Contudo, a Política Nacional de Resíduos Sólidos (PNRS - Lei 12.305/2010) prevê o fim dos lixões e aterros controlados, e colocou os resíduos eletroeletrônicos no rol da logística reversa obrigatória (artigo $33^{\circ}$ ), o que implica, ao menos em teoria, que esse tipo de destinação não deverá mais acontecer. ${ }^{35} \mathrm{O}$ gestor de resíduos sólidos urbanos no município do Rio de Janeiro (Companhia Municipal de Limpeza Urbana COMLURB) reportou um percentual de 0,13\% de REEE em uma amostragem de caracterização realizada em RSU enviados para o Aterro Controlado de Jardim Gramacho durante 2008, representando $0,64 \mathrm{~kg}^{\mathrm{ano}}{ }^{-1}$ per capita nesse ano. Em 2012, segundo a COMLURB, o percentual de REEE passou a $0,20 \%{ }^{36}$ Esses dados são estimativas e aplicam-se apenas a um município dentre os mais de 5,5 mil existentes.

É importante assinalar que o fato de haver lei não significa gestão eficiente do resíduo eletroeletrônico. Apesar de possuir a legislação mais avançada no mundo, somente cerca de um terço dos equipamentos eletroeletrônicos (EEE) na Europa é recolhido. $^{37} \mathrm{O}$ resto vai para aterros, é incinerado ou exportado ilegalmente, ${ }^{17} \mathrm{em}$ desacordo com a Convenção de Basileia (Controle de Movimentos Transfronteiriços de Resíduos Perigosos), ${ }^{38}$ do qual o Brasil é signatário. Dentre os destinos dessa exportação ilegal, contam-se países da África (Nigéria, Quênia, Gana etc.) e da Ásia (China, Vietnã etc.). Nesses locais o trabalho com esses resíduos se constitui em um grave problema socioambiental, como será detalhado mais adiante. Além de ser o maior gerador de resíduos eletroeletrônicos do mundo, só $14 \%$ deles é reciclado nos EUA. ${ }^{37,39}$ Outros dados apontam uma taxa de reciclagem de 17,7 \% em 2009 naquele país; o resto vai para aterros, é queimado ou exportado ilegalmente. Esse nível de reciclagem é até inferior ao do lixo municipal $(33,8 \%){ }^{39}$ Estima-se que cerca de $20 \%$ dos laptops parem em aterros nos EUA devido a falhas no sistema de devolução (take-back) e falta de conscientização da população. ${ }^{40}$

Há estados norte-americanos que consideram não haver perigo nos EEE 
descartados em aterros ou que houve superestimação dos riscos ambientais. ${ }^{40}$ Mas há quem afirme que a percepção das consequências do descarte dos resíduos eletroeletrônicos é ainda incipiente em termos ambientais e de saúde humana. ${ }^{41}$

\section{Impactos Ambientais dos Resíduos Eletroeletrônicos (REE)}

Impactos ambientais são os resultados da ação direta do resíduo eletroeletrônico, seja inteiro ou em fragmentos, no meio ambiente como decorrência de ações das intempéries naturais (calor, frio, chuva, vento, microorganismos) sobre componentes desse resíduo, favorecendo a intromissão de elementos e compostos tóxicos (água, ar, solo), com consequências as mais diversas sobre os seres vivos presentes naqueles ambientes. Portanto, o simples ato de descartar um EEE no ambiente, bem como frações não aproveitadas nos processos de desmonte desses equipamentos, causará impactos ambientais em algum momento no futuro. Os REEE são tidos como o problema ambiental de maior crescimento nos últimos anos. ${ }^{42,43} \mathrm{O}$ descarte direto no ambiente pode levar a impactos sobre o solo, o ar e às águas subterrâneas. ${ }^{44-46}$

Resíduos de plásticos não biodegradáveis e materiais persistentes de composição totalmente diversa (como as placas de circuito impresso) daqueles de origem natural oriundos dos REEE são potenciais candidatos a tecnofósseis, ${ }^{27,47}$ posto que podem se sedimentar em diversas regiões do planeta, fornecendo um testemunho de tempo geológico (camada estratigráfica) distinto das eras anteriores devido à sua composição peculiar. ${ }^{19,20,26,28,47}$

A rigor, o primeiro impacto dos resíduos eletroeletrônicos não advém do momento de seu descarte. A produção cada vez maior e mais rápida de novas gerações de EEE traz duas grandes implicações: o elevado consumo dos recursos naturais empregados na fabricação destes e a destinação final inadequada. ${ }^{4}$ Para a fabricação de um computador e seus periféricos básicos (teclado, mouse, impressora e monitor de tubos de raios catódicos - CRT, cathode ray tube), com massa em torno de $20 \mathrm{~kg}$, são necessários quase $2 \mathrm{t}$ de insumos (com destaque para a água), ou seja quase 100 vezes a massa do produto (essa quantidade é reduzida para $\sim 1,8$ t no caso de monitores de tela plana). Para um simples chip emprega-se mais de 30 vezes a sua massa em insumos. ${ }^{16,48}$ Por isso, o primeiro grande impacto dos resíduos eletroeletrônicos não é o seu descarte, mas sim a extração dos insumos necessários à sua fabricação. Mesmo antes de ser descartado, os tubos de CRT também impactam o meio ambiente pelo enorme consumo de energia elétrica durante sua vida útil. ${ }^{49}$ Esses dados mostram como os EEE se inserem no contexto da "Grande Aceleração" antes mesmo de se converterem em REEE. 19,20

Estudos científicos assinalam que 0 descarte de placas de circuito impresso (PCI) é uma fonte de liberação de metais tóxicos e retardantes de chama bromados em aterros sanitários segundo os ensaios TCLP (toxicity characteristic leaching procedure) da EPA (Environmental Protection Agency, EUA) (Figura 2). ${ }^{50}$ Os processos de mobilização desses constituintes tóxicos envolvem reações de oxirredução, despolimerização e volatilização de parte dos produtos formados. Os retardantes de chama são recalcitrantes e bioacumulados na cadeia alimentar, ${ }^{51} \mathrm{da}$ mesma forma que os metais tóxicos. Por isso, as $\mathrm{PCl}$ têm potencial de contaminar solos e lençóis freáticos. ${ }^{52}$

Os resíduos eletroeletrônicos podem vir a ser uma nova fonte de contaminação por cádmio (presente no "pó de fósforo" nos monitores de CRT, pigmentos e em plastificantes), ${ }^{53,54}$ mercúrio (pilhas, baterias, plastificantes etc. $)^{50,55}$ e cromo hexavalente (pigmentos, plastificantes). ${ }^{56,57}$ As contaminações ambientais diretamente devidas ao descarte dos resíduos eletroeletrônicos estão mais relacionadas à forma incorreta como ele é manuseado em 
países da Ásia ou África (descarte das sobras desse lixo no ambiente) do que ao comportamento dele em si descartado diretamente no ambiente, conforme relatado em vídeos e reportagens publicadas pela mídia e por Organizações Não Governamentais (ONGs). ${ }^{58} \mathrm{Em}$ áreas de reciclagem informal na China, Gana e Nigéria, solos e plantas se acham altamente contaminados por metais e polímeros tóxicos e retardantes de chama bromados, os quais acumulam-se e causando até mesmo efeitos genotóxicos (danos ao DNA) às plantas. ${ }^{49}$

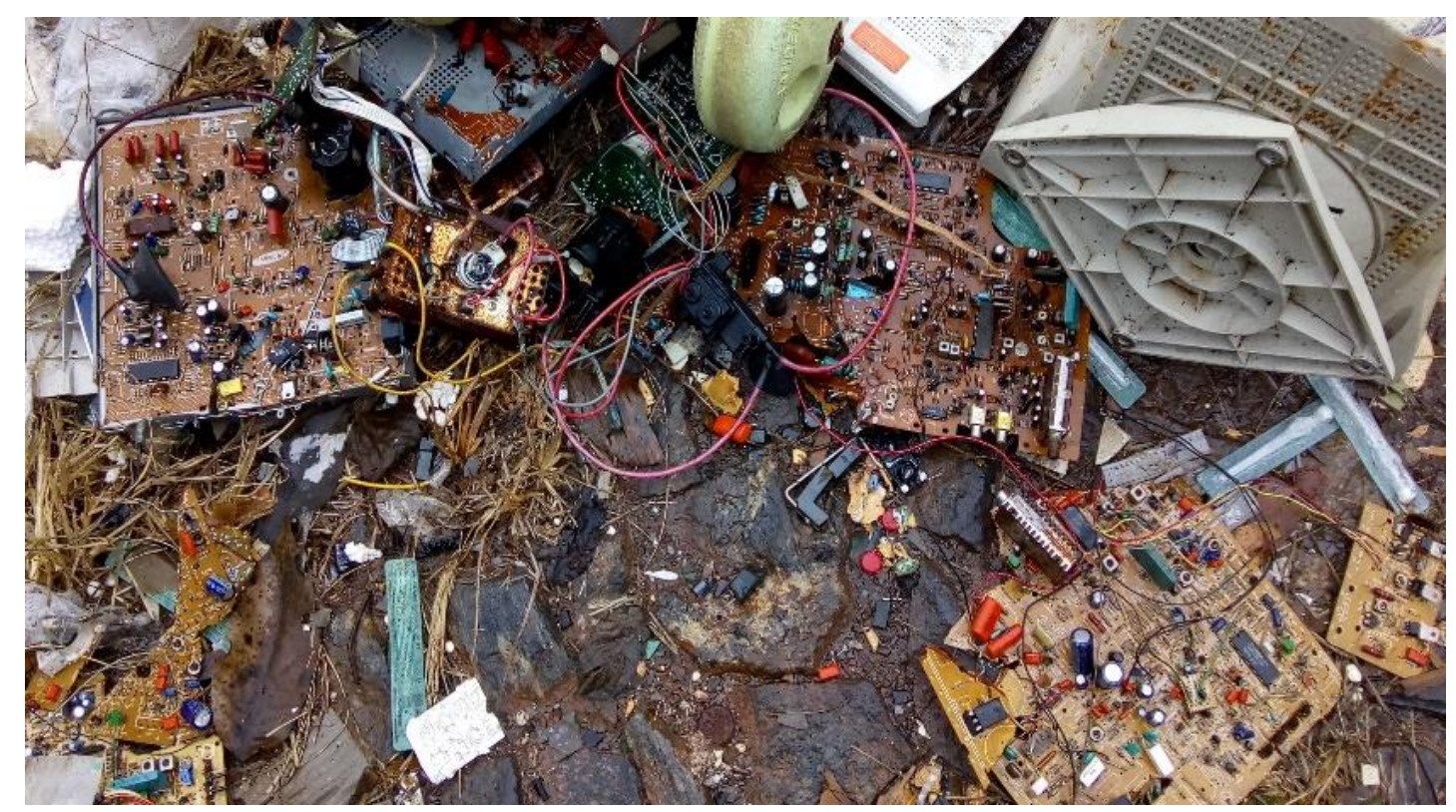

Figura 2: Placas de circuito impresso em um lixão

A combustão (queima) de $\mathrm{PCl}$ contendo retardantes organobromados em condições ambientalmente mais seguras exige temperaturas muito elevadas (800-1400 ㄷ) e um excesso de ar até $90 \%$ acima do ponto estequiométrico, ${ }^{59}$ somente possível mediante emprego de um incinerador licenciado para resíduos perigosos dotado de mecanismos de controle ambientais adequados. $\mathrm{O} \mathrm{HBr}$ e $\mathrm{Br}_{2}$ são os principais produtos de bromo formados, mas o controle dos gases de resfriamento é crítico por conta da formação de dioxinas e furanos (poli)bromados. Além disso, $\mathrm{HBr}$ e $\mathrm{Br}_{2}$ são corrosivos, atacando os equipamentos do processo. ${ }^{60}$ Assim, não é de se estranhar que a queima sem controle das $\mathrm{PCl}$ pode formar dioxinas e furanos bromados no ambiente, ${ }^{61}$ além de liberar poeiras contendo metais tóxicos (compostos de mercúrio e cádmio podem volatilizar ou mesmo sublimar em temperaturas elevadas). ${ }^{49}$ Mesmo a exposição das $\mathrm{PCl}$ à luz solar direta, particularmente em dias de forte calor, pode liberar parte dos retardantes de chama, contribuindo para uma contaminação ambiental latente. ${ }^{45,59}$

O chumbo é um dos componentes mais críticos do resíduo eletroeletrônico devido ao amplo emprego em soldas e tubos de CRT. ${ }^{62}$ Embora proibido na Europa desde 2005, pode haver chumbo nos resíduos de produção de EEE (bem como nas próprias versões mais antigas desses produtos). ${ }^{63}$ As leis européias não controlam o fluxo de metais tóxicos gerados nas etapas de extração de matériasprimas e manufatura industrial. Por isso, pode aparecer chumbo em cadeia de produção de produtos sem o metal. Há uma tendência ao declínio de chumbo em EEE, mas não na cadeia produtiva. ${ }^{64}$ Condições ácidas ambientais podem lixiviar o chumbo, introduzindo-o nos ciclos ambientais naturais ${ }^{64}$ (TCLP $=5 \mathrm{mg} \mathrm{L}^{-1}$ para o elemento) ${ }^{65}$ Por isso, mesmo o chumbo aparentemente 
"imobilizado" como óxido no vidro plumbífero de tubos CRT deve ser tratado como potencial poluente ambiental. Numa visão mais geral, o resíduo eletroeletrônico deve ser visto como uma nova fonte de contaminação ambiental (e à saúde) por chumbo. ${ }^{66}$ Há uma estimativa de 6 milhões de toneladas de CRT na China, contendo $\sim 500$ mil toneladas de chumbo. ${ }^{67}$ Até nos EUA, as estimativas são imprecisas. ${ }^{68}$ O impacto decorrente da incineração desse material é muito maior do que pela desmontagem manual e reciclagem mecânica, devido à difusão pelo ar dos gases e particulados da queima. Por isso, a presença de CRT junto aos RSU que são incinerados é um grave problema ambiental (e de saúde pública). ${ }^{69}$ Nunca é demais reforçar que descartar o resíduo eletroeletrônico no ambiente também significa desperdiçar a oportunidade de recuperar partes diretamente recicláveis e metais de alto valor agregado como ouro, prata, cobre etc. ${ }^{70}$

A introdução de substâncias tóxicas não antes vistas na natureza, como os retardantes de chama bromados e metais que normalmente se acham na forma de composições minerais não lixiviáveis é uma das consequências do descarte de REEE no ambiente, e uma das características relacionadas ao Antropoceno. ${ }^{71}$

\section{Riscos à Saúde Decorrentes do Manejo Incorreto dos Resíduos Eletroeletrônicos (REE)}

O foco das preocupações com a higiene e saúde ocupacionais advém de duas fontes: metais tóxicos presentes em muitos dos componentes dos resíduos eletroeletrônicos, e compostos orgânicos, particularmente os retardantes de chama bromados.

Os perigos ocultos na aparência "inofensiva" das partes dos EEE são vários. Por exemplo, a não indicação da ausência ou presença de retardantes de chama bromados coloca grandes desafios para a separação e a reciclagem de plásticos de EEE. ${ }^{72}$ Outros desafios para o manuseio correto da fração plástica são: pigmentos (óxidos de titânio(IV), zinco, cromo(VI), ferro(III), cádmio etc.), plastificantes (compostos de bário, cádmio, chumbo, estanho, zinco, bifenilas policloradas etc.), poliuretanas e retardantes de chama sem bromo (como os à base de antimônio). ${ }^{73,74} \mathrm{~A}$ correta escolha de equipamentos de proteção individual (EPIs) e o treinamento da mão-de-obra dependem da tipologia do resíduo que irão lidar.

Os casos de danos à saúde decorrentes do manuseio inadequado de EEE são bem documentados nos países asiáticos, particularmente na China, onde se concentra grande parte da indústria informal de reciclagem de EEE. Mas nem mesmo países desenvolvidos escapam de problemas. Estudos de caso na Espanha, com a ajuda de ferramentas estatísticas, confirmam a maior chance de câncer e outras doenças nas vizinhanças de unidades de reciclagem, reprocessamento e incineradores. Os órgãosalvo principais são o estômago, fígado, pulmão, rim e ovário. ${ }^{75}$ Esses estudos enfatizam a necessidade do controle do ambiente interno (desde as etapas de moagem/trituração das $\mathrm{PCl}$ ), e de implementar um tratamento dos efluentes gerados nas atividades de reciclagem/desmonte de EEE. ${ }^{75}$

Em Guiyu (China), os recém-nascidos tendem a apresentar baixo peso corporal e maiores teores de chumbo no sangue, dentre outras deficiências neonatais. ${ }^{76} \mathrm{Em}$ áreas de reciclagem informal retardantes de chama bromados causam efeitos tóxicos e mesmo genotóxicos aos indivíduos expostos nesses locais. ${ }^{58} \mathrm{Em}$ dois locais de reciclagem informal na China, a quantidade de dioxinas e furanos a que os trabalhadores estão expostos excede os limites estabelecidos pela Organização Mundial da Saúde (OMS). ${ }^{77}$ As rotas de ingestão alimentar e inalação do ar são as mais importantes vias de contaminação. ${ }^{77}$ Os trabalhadores dos locais informais de reciclagem e as crianças são as mais afetadas. As fontes principais de dioxinas e furanos são 
a queima a céu aberto (poluem o ar) e as lixívias ácidas (poluem solos e águas). Outros estudos focam a acumulação desses compostos em várias partes do corpo humano. ${ }^{77}$

O impacto da reciclagem informal em países da Ásia e África ganhou muita atenção nos últimos anos. ${ }^{40,78}$ Documentários e vídeos disponíveis no Youtube, portais de Organizações Não-Governamentais (ONGs) e órgãos da administração pública de diversos países mostram como é a realidade nesses locais. O conjunto destes vídeos é claríssimo: as consequências imprevisíveis de um manejo incorreto dos EEE sobre a saúde e o meio ambiente, e cujas imagens podem chocar mesmo pessoas de pouca sensibilidade.

Devido à presença de elementos e compostos altamente danosos à saúde e impactantes ao meio ambiente, a adoção das melhores práticas de controle da higiene e saúde ocupacionais e dos riscos ambientais nos locais de trabalho devem acompanhar todas as fases de desmonte e processamento dos $E E E$, inclusive no que diz respeito ao envio a empresas terceirizadas de reciclagem/reprocessamento.

Os procedimentos aparentemente "limpos" como britagem, moagem e trituração são capazes de liberar retardantes de chama bromados de $\mathrm{PCl}$ de EEE. ${ }^{79,80}$ As poeiras produzidas na moagem/trituração são consideradas uma enorme fonte de risco de contaminação ambiental e humana, especialmente em locais informais de reciclagem. ${ }^{73} \mathrm{~A}$ origem da poeira e mesmo de gases e vapores se deve à tenacidade e resistência das $\mathrm{PCl}$ durante o processo de moagem. ${ }^{81}$ Há uma correlação bem estabelecida de chumbo (oriundo de soldas) em sangue de crianças de Guiyu (China) e poeiras de EEE de unidades recicladoras. $O$ mesmo se aplica ao cromo e ao bromo (proveniente de retardantes de chama). ${ }^{80}$ Nesses locais, que são geralmente fechados, há tendência ao acúmulo de poeira nas áreas internas, equipamentos etc. ${ }^{82,83}$ As crianças, grávidas, idosos e adolescentes estão sujeitas à contaminação em locais informais por conta do trabalho tipicamente familiar. ${ }^{49,73}$
É comum que os trabalhadores dos setores informal e formal não tenham informações sobre os riscos a que estão expostos. Uma linha de reciclagem bem projetada deve ser equipada com sistema de remoção de poeira e resíduos. ${ }^{10}$ Para $\mathrm{PCl}$ de equipamentos de grande porte, esta etapa é inevitável para poder compactar o material em um volume menor e permitir a separação física supracitada. ${ }^{79}$ Somente pessoal previamente treinado, sensibilizado e conscientizado pode trabalhar com desmonte e segregação dos componentes dos REEE, empregando equipamentos de proteção individual (EPIs) adequados.

Os tubos de raios catódicos (CRT) exigem um grande cuidado com o controle de saúde ocupacional. ${ }^{82}$ São pesados e estão sob vácuo. Eles são compostos por uma tela (ou vidro) frontal e do chamado vidro plumbífero. A face interna da tela frontal contém o chamado "pó de fósforo", mistura complexa de substâncias que pode conter zinco, cádmio, vanádio, cobalto, ferro, cromo, bário, estrôncio, silício e elementos da série lantanídea. Portanto, esse componente dos tubos de CRT é altamente tóxico. $\mathrm{Na}$ aspiração para retirada desse material, o controle do ar circundante é crucial para assegurar um bom ambiente de trabalho. O mesmo se aplica quando o pó é retirado do saco do aspirador, para evitar a ressuspensão do mesmo.

O chumbo é conhecido pelos seus efeitos tóxicos sobre o organismo humano desde o tempo do Império Romano; o envenenamento envolvendo este metal é chamado saturnismo. ${ }^{84,85} \mathrm{O}$ cádmio e o cromo hexavalente também têm registros de efeitos tóxicos sobre a saúde humana. ${ }^{54,67}$ Assim, o tubo de CRT é uma fonte de risco à saúde quando submetido a um processo de desmontagem sem as devidas precauções.

Até um cartucho ou tonner de impressora exige cuidados em seu manuseio. É muito comum o reúso dos mesmos no Brasil, mas não podem ser indefinidamente recarregados, sendo recomendado um máximo de três ciclos. ${ }^{86}$ No Brasil, o cartucho não recarregável é geralmente descartado junto com os RSU. Esta prática, de elevado 
impacto ambiental, representa um perigo à saúde se 0 cartucho for manuseado incorretamente (presença de quantidades residuais de solvente e de outros componentes da tinta), podendo ser considerada uma lacuna na gestão do produto no Brasil. Em 2008, mais de 200 milhões de cartuchos foram descartados em aterros só nos Estados Unidos. Em 2007, menos da metade dos cartuchos usados foi reutilizada ou reciclada na Europa e nos Estados Unidos. ${ }^{86}$ Cada cartucho tem em média 4-5 mg de ouro e $110-130 \mathrm{mg}$ de cobre. ${ }^{86} \mathrm{Em} \mathrm{2016}$, calcula-se um descarte da ordem de 475 milhões de cartuchos e tonners em todo o mundo. ${ }^{87}$ Estima-se nesse mesmo ano no Brasil que 27 \% dos 120 milhões de cartuchos circulantes no mercado interno sejam remanufaturados ou compatíveis. ${ }^{87}$

\section{Logística Reversa e Fluxo de Equipamentos Eletroeletrônicos (EEE) Usados}

\subsection{Experiências pelo mundo}

A logística reversa visa mitigar os danos ambientais do descarte de EEE no meio ambiente e evitar perdas de materiais de valor nesses produtos, por meio de encaminhamento dos EEE à indústria de reciclagem, ${ }^{57}$ evitando que sejam descartados com os resíduos sólidos urbanos. ${ }^{33}$ Assim, a logística reversa começa pela coleta de produtos ainda utilizáveis, obsoletos ou inservíveis. A decisão pelo reúso/remanufatura (produtos de segunda mão) ou pela reciclagem depende do estado do EEE descartado. ${ }^{88}$

A logística reversa deve prover sustentabilidade ambiental, econômica e social simultaneamente. ${ }^{58}$ Sem uma logística reversa consolidada a cadeia de reciclagem e processamento não atingirá uma escala viável. Numa acepção mais ampla, vai desde o consumidor até a indústria recicladora, passando por diversas etapas (centros de coleta, transporte, centros de triagem e desmontagem etc.). ${ }^{60,89} \mathrm{O}$ acesso a facilidades e às últimas novidades tendem a alterar os hábitos comportamentais dos consumidores, influenciando o ciclo de vida dos produtos. ${ }^{90}$ Estes ciclos tendem a ser cada vez mais curtos; a expansão do mercado consumidor (maior acessibilidade aos EEE) e a proposta de novos tipos e versões desses produtos exigem uma logística reversa robusta e eficaz. ${ }^{52}$ Muitos consumidores trocam seus produtos eletroeletrônicos por desejar a "última palavra em tecnologia", mesmo que o produto antigo ainda funcione. ${ }^{88}$

Os EEE domésticos são um importante fluxo do resíduo eletroeletrônico. Por isso, sem a participação da população, não se terá o sucesso na logística reversa dos mesmos. ${ }^{63} \mathrm{E}$ preciso motivar as pessoas quanto ao potencial de reciclagem (metais e energia) e à viabilidade técnica desse procedimento. Como no sistema de logística reversa os consumidores são responsáveis pela destinação ambientalmente adequada dos resíduos que geram, ${ }^{31}$ eles se tornam parte vital como sujeitos ativos para dar início ao processo, por meio da coleta e descarte seletivos. $^{69}$ A diversidade cultural, administrativa, geográfica, burocrática e perfil social de uma população levam a uma logística reversa diferenciada para cada país. ${ }^{65}$ Normas de conduta moral, educação e esclarecimento ao público sobre os benefícios da reciclagem, tornam esta mais convincente e acessível, mas também medidas complementares são necessárias para motivar as pessoas - postura pró-ativa ambiental: informar os perigos do descarte do EEE no ambiente, coleta (dropback) dos EEE antigos, educação em todos os níveis de escolaridade, inclusive envolvendo igrejas e organismos não educacionais são estratégias para sensibilizar os consumidores. ${ }^{8}$ Em inúmeros países, não há sistema oficial de coleta estabelecido e controle das atividades em curso envolvendo EEE. ${ }^{91} \mathrm{Na}$ Grã-Bretanha, consumidores só conhecem, em geral, iniciativas públicas de coleta seletiva de EEE, porém pouco conhecem as rotas de encaminhamento dos 
produtos usados. ${ }^{88} \mathrm{Na}$ Malásia, uma idéia original é focar a educação tendo por base seu sistema universitário. ${ }^{50}$

Os maiores impulsionadores para políticas de logística reversa são a legislação do país, incentivos aos consumidores e a demanda destes por novos produtos. ${ }^{57}$ São oito os fatores a serem considerados numa logística reversa: legislação, demanda dos clientes, custo/benefício estratégico, aspectos ambientais, escala e qualidade, incentivos, recursos e integração-coordenação das partes envolvidas. ${ }^{57}$ Quatro problemas são comumente identificados nessa análise: ${ }^{37}$ leis não aplicadas com rigor ou inadequadas; incentivo à reciclagem insuficiente; programas de reciclagem e coleta inadequados; consumidores não esclarecidos sobre os perigos do descarte inadequado dos $E E E$, ou não sabem o que fazer com eles. Esse último tópico é bem exemplificado com a constatação de que nos EUA e Tailândia, idade avançada, postura pró-ambiental inexistente, nível de educação insuficiente, tamanho e espaço da casa, afeição pelo produto, localização geográfica, sexo do possuidor, logística reversa disponível e guarda de dados sigilosos são argumentos para a guarda de EEE velhos nas residências. ${ }^{17,63}$ No caso de celulares, estima-se que só $15 \%$ dos aparelhos obsoletos são reciclados; em geral, ficam esquecidos e guardados nas residências. ${ }^{69}$ Especificamente nos EUA, estima-se que existam mais de 80 milhões de TVs guardadas. ${ }^{68}$

Há grandes dificuldades a serem vencidas no estabelecimento de uma logística reversa. Talvez uma das mais relevantes seja estabelecer uma modelagem matemática dos fluxos de EEE em um país ou mesmo pelo mundo (o que exige uma grande quantidade de dados nem sempre disponíveis ou confiáveis). ${ }^{56,57,60,82,92-94}$ Estimativas de geração de resíduos eletroeletrônicos são difíceis de serem obtidas devido à velocidade e circulação de produtos novos e usados. ${ }^{52}$ Afora isso, os componentes de um EEE podem provir de várias partes do mundo, numa cadeia complexa desde a extração dos recursos naturais até a montagem do produto final..$^{25} \mathrm{Um}$ detalhamento desse fluxo de EEE deve incluir: custos de coleta, transporte e tratamento, bem como receitas auferidas com a venda dos produtos obtidos. ${ }^{60} \mathrm{O}$ mercado informal dificulta a estimativa de um fluxo de $\mathrm{EEE},{ }^{91}$ bem como o fluxo de produtos de segunda mão, guardados nas residências ou a não inclusão de segmentos industriais e comerciais. ${ }^{56}$ Por essas razões, frequentemente as estimativas são subestimadas. ${ }^{91}$ As densidades populacionais em áreas rurais e urbanas, bastante diferentes, impactam diretamente a logística reversa por apresentarem diferentes perfis de consumo e vida útil de um mesmo EEE. ${ }^{55,90} \mathrm{~A}$ extensão da vida útil dos EEE (reúso, revenda, recondicionamento) não impacta somente o ciclo de vida mas também o de energia usada na fabricação dos mesmos, e isso é um grande complicador na obtenção de uma modelagem de fluxo fidedigna. ${ }^{40,89} \mathrm{~A}$ extensão da vida útil dos EEE tem importância em países em desenvolvimento e subdesenvolvidos, face aos diferentes poderes aquisitivos da população, geralmente baixo, ${ }^{50}$ e isso inclui programas de doação a pessoas sem recursos para inclusão digital. ${ }^{78}$ Mesmo em países desenvolvidos pode-se encontrar problemas de divulgação e conhecimento de resultados de programas voluntários de devolução (dropback) feitos por empresas e órgãos de caridade, como no Reino Unido. ${ }^{95}$

O estabelecimento de sistemas abertos (incluindo o mercado informal, a remanufatura e o recondicionamento) ou fechados (da fábrica para ela mesma) para o processamento dos EEE recolhidos é outro desafio das logísticas reversas. ${ }^{57}$ Acredita-se que o ideal é estabelecer um sistema de reciclagem fechada e reúso do material recuperado em novos produtos. ${ }^{30}$ Quanto mais produtos obtidos para venda e reciclagem, mais complexa é a estrutura da logística reversa. ${ }^{60} \mathrm{O}$ pagamento de uma taxa na compra do EEE novo para financiar a coleta destes após ser devolvido pelo consumidor (take-back) ajuda a financiar a logística reversa, retirando produtos que acabariam no mercado informal ou em aterros. ${ }^{37,63} \mathrm{~A}$ eliminação ou a inserção do setor informal de reciclagem (informal waste sector - IWS) ao 
setor formal legalizado é essencial para aumentar a eficácia de uma logística reversa, pois minimiza os efeitos ambientais e à saúde das pessoas decorrentes de uma gestão amadorística dos EEE. ${ }^{50,54,58}$ A simples proibição ou competição com o setor informal não resolve os problemas associados a essas práticas. ${ }^{96}$ Para evitar problemas de cunho social, a integração do IWS à logística normal deve ser feita dentro de critérios de saúde ocupacional e ambiental corretos. ${ }^{58} \mathrm{O}$ setor produtivo pode encarar esse processo de forma reativa (cumprir só o essencial), próativa (buscar vantagens econômicas e de imagem com programas de reciclagem e coleta) e ainda integrar aspectos ambientais à sua rede de negócios e concepção de produtos. ${ }^{78}$ É comum a adoção das chamadas práticas "verdes" que visam facilitar a inserção de seus produtos no mercado consumidor sob a alegação de serem fabricados segundo as melhores práticas ambientais. ${ }^{97}$

Outro desafio apontado em algumas pesquisas ${ }^{61}$ é a dimensão da logística reversa: global ou local (regional)? Em princípio, a grande vantagem dos fluxos locais (regionais) é reduzir o custo do transporte de EEE. ${ }^{89}$ Não são apenas questões de saúde e ambientais que estão em jogo, mas também a falta de iniciativas oficiais e de controle dos produtos remanufaturados e das iniciativas de reciclagem.${ }^{96} \mathrm{~A}$ centralização das atividades da logística reversa em um local reduz custos de transporte e a emissão de gases de efeito estufa. ${ }^{58} \mathrm{~A}$ regionalização dos fluxos reduz as margens de incerteza, como num estudo feito na Coréia do Sul. ${ }^{56}$ No transporte, volume e massa influenciam o tipo de veículo, frequência e custos. Para grandes extensões territoriais, torna-se variável crítica e, como um todo, deve ter seu impacto no custo da logística minimizado. ${ }^{60,69,89}$

Os altos custos de tratamento nos países desenvolvidos levam à exportação para países em desenvolvimento. ${ }^{98} \mathrm{O}$ fluxo dos EEE usados tende a seguir para países sem regulamentação adequada ou inexistente. ${ }^{63}$ Na Ásia e na África a fraqueza de algumas legislações favorece a entrada ilegal de EEE de outras partes do mundo. ${ }^{39}$ Nesses países, prolifera uma indústria informal com riscos à saúde e ao meio-ambiente. ${ }^{39}$ De 50 a $80 \%$ dos EEE dos países desenvolvidos vai para países onde é reciclado ou reutilizado sem critérios, frequentemente violando os termos da Convenção de Basileia. ${ }^{39,69,78}$ Guyiu, na China, é a cidade-símbolo dessa prática. ${ }^{78}$ As economias dos países em desenvolvimento são frágeis e dependem muito de quaisquer iniciativas, incluindo recuperar materiais valiosos de EEE com métodos ambientalmente agressivos, ${ }^{98}$ com baixa eficiência. ${ }^{61}$ A implementação de leis ambientais não evita o tráfego ilegal de EEE (China, Vietnã, Malásia, Indonésia, Filipinas, Camboja, Índia etc.), ou seja, a legislação desses países não é suficiente para cobrir os aspectos negativos da movimentação e reciclagem informais..$^{55,61,98}$ Há mesmo países ainda sem qualquer iniciativa ou legislação. ${ }^{62}$ Filipinas, Vietnã, África do Sul, Nigéria, Gana, Paquistão e Índia são exemplos de movimentação de fluxos de EEE depois da entrada em vigor de legislação mais rígida a respeito desses resíduos na China. ${ }^{78} \mathrm{Em}$ alguns poucos casos, incluindo o Brasil, países em desenvolvimento tendem a exportar itens para serem processados em unidades instaladas em países desenvolvidos por falta de escala interna, mesmo para uma reciclagem em menor escala. ${ }^{97}$

O impacto da reciclagem informal em países da Ásia e África ganhou muita atenção nos últimos anos, e muitas medidas vem sendo tomadas para acabar com esse mercado informal, que apresenta muitas dificuldades operacionais como quantificação precária de fluxos, tipos de destinação final, reexportação etc. ${ }^{40,78} \mathrm{~A}$ política mais adequada é estruturar grupos e plantas de reciclagem legal de EEE nesses países como forma de acabar com a indústria informal e manual vigente, ${ }^{69}$ acompanhada de políticas governamentais para elevar os níveis de coleta, condições de trabalho e capacitação dos envolvidos, eliminando com isso as práticas inadequadas documentadas. ${ }^{96}$ Há plantas de processamento oficiais em alguns 
países asiáticos, por exemplo, na Índia e nas Filipinas, em parceria com a Alemanha e a Suíça; ${ }^{39}$ de fato, a indústria indiana de EEE teve crescimento elevado nos últimos anos, característica essa típica dos BRICs (Brasil, Rússia, Índia, China e África do Sul). ${ }^{77} \mathrm{Na}$ África a situação ainda é incipiente. ${ }^{78} \mathrm{~A}$ elevada taxa de urbanização da América Latina facilita a penetração de EEE, especialmente celulares e computadores. ${ }^{39}$ Mas não há país latinoamericano que tenha uma política consolidada e operacional para a logística reversa de EEE, favorecendo a informalidade como se verifica na Ásia e África. ${ }^{18,39}$

A chamada "abordagem/filosofia do melhor dos dois mundos" (best of the two words approach), desmontagem em países em desenvolvimento em locais de concentração (centros), com relativamente poucos requisitos técnicos necessários, seguido de envio dos produtos da segregação inicial para sistema de rede internacional, envolvendo países industrializados e mesmo até em desenvolvimento, é amplamente criticado por não garantir as melhores condições de trabalho nesses últimos, apesar da propalada justificativa de incentivo ao emprego e ao desenvolvimento econômico. ${ }^{97,99} \mathrm{~A}$ dependência dos países da Ásia e da África dos países desenvolvidos não é contemplada por este modelo, nem sua veracidade foi ainda comprovada. ${ }^{97} \mathrm{~A}$ adoção de tecnologias em escala menor (local) seria a solução racional. ${ }^{6}$ Trocas de experiências e tecnologias entre países desenvolvidos e em desenvolvimento podem auxiliar na concepção de soluções globais e locais para o fluxo de EEE. ${ }^{61}$

Uma das respostas à geração dos REEE é a criação de legislações que corresponsabilizam os fabricantes pelos produtos após o fim de suas vidas úteis. A Europa possui o conjunto de leis mais evoluído do mundo. ${ }^{39,69}$ A política segue a ordem: evitar a geração, fomentar o reúso, reciclo e outros modos de processamento, e ainda reduzir teores de metais e constituintes perigosos nos produtos das gerações mais recentes. ${ }^{69} \mathrm{O}$ princípio de responsabilidade estendida ao produtor (extended producer responsibility - EPR), originária da legislação europeia, foca o aumento da recuperação de materiais a partir dos resíduos eletroeletrônicos, tirando o ônus de gestão do produto usado do consumidor e do governo. ${ }^{25}$ Esse princípio foi recentemente adotado em países latino-americanos como Argentina, Brasil, Colômbia e Peru, bem como na Coreia do Sul, Taiwan, Japão e África do Sul. ${ }^{39,61,78} \mathrm{Em} 2012$ mais da metade dos estados americanos e das províncias canadenses adotaram legislações para lidar com o problema do EEE; a maioria delas está baseada no princípio EPR. ${ }^{49}$ No estado atual a legislação federal desses países não favorece a implantação de um sistema de EPR que resulte em uma gestão de REEE ambientalmente mais adequada ; a responsabilidade financeira por essa gestão recai basicamente sobre os consumidores. ${ }^{66} \mathrm{~A}$ adoção do princípio EPR pode arruinar a cadeia de reúso e revenda de EEE na Índia, Tailândia e Camboja, fortemente centrada na informalidade e no mercado de produtos de segunda mão. ${ }^{39,50,55}$ Portanto, observa-se que uma solução adequada a uma região do mundo não implica necessariamente em ser uma solução para outra região. ${ }^{77,98}$

\subsection{Situação no Brasil}

A indústria de EEE no país movimenta mais de $4 \%$ do PIB, colocando o país em destaque no cômputo mundial, por exemplo, é o 50 produtor mundial de computadores. ${ }^{25,39,100}$ Porém, o Brasil entrou em trabalhos internacionais sobre resíduos eletroeletrônicos apenas muito recentemente, mais de 10 anos depois dos primeiros relatos oriundos da Europa e da Ásia. A entrada em vigor da Política Nacional de Resíduos Sólidos (PNRS) em agosto de $2010,35,39$ regulamentada pelo Decreto no $7.404 / 2010,{ }^{101}$ e baseada nos conceitos de EPR, ciclo de vida do produto e da logística reversa de diversos produtos, deu o start up que faltava para a organização de um sistema de gerenciamento dos EEE usados. ${ }^{102,103} \mathrm{Em}$ 2017 foi publicado o Decreto no 9.177 que regulamenta a ampla obrigatoriedade da 
implantação do Sistema de Logística Reversa por parte das empresas a partir de acordo setorial que venha a ser firmado com a União. ${ }^{104}$ Segundo a PNRS, a implementação do Sistema de Logística Reversa deve ser realizada por meio de regulamentação (leis, decretos e normas), acordo setorial ou termos de compromisso. Tanto o acordo setorial como os termos de compromisso devem ser firmados a partir do comprometimento entre governo, fabricantes, importadores, distribuidores ou comerciantes, cabendo ao Instituto Estadual do estado pertinente a fiscalização das ações para a destinação relativas à gestão desses resíduos em seu território. ${ }^{31,35,101}$

Há alguns estados com alguma legislação específica para EEE (SP, MG, SC, PR). ${ }^{39}$ Por exemplo, no Estado do Rio de Janeiro, equipamentos de informática e telecomunicação devem ser devolvidos ao comércio ou depositados em pontos de entrega voluntária (PEV). ${ }^{31}$ Apesar de ser o ponto de partida, existe deficiências relativas a regulamentações e tempos de adequação de todos os atores envolvidos. ${ }^{105,106}$ Apesar de o Brasil ter uma taxa crescente de geração de lixo eletrônico, atualmente existem poucos sistemas de gestão adequados em operação, com a maior parcela dos REEE sendo ainda destinada a aterros sanitários ou entrando em cadeias informais.

Os brasileiros também se tornaram mais sensíveis ao reconhecimento da necessidade de uma abordagem sustentável para o descarte de produtos eletrônicos. Mesmo que a maioria pare no nível das intenções, em grande parte devido à pouca difusão das informações relativas aos impactos desses resíduos, ${ }^{31}$ há um pano de fundo favorável de atitudes, expectativas sociais e demandas por meios de autocapitalização que podem ajudar a uma conversão rápida e em massa de intenções em comportamentos. ${ }^{106}$

Os dados de consumo, fabricação e vida útil média disponíveis são por vezes contraditórios e não plenamente confiáveis. Nesse aspecto, as dificuldades do país não são muito diferentes do resto do mundo, mas são agravadas pela extensão territorial e por fatores culturais. ${ }^{105,106}$ Foi feita uma tentativa de mapear a circulação de EEE no Brasil a partir de alguns exemplos (geladeiras, TVs, freezers, máquinas de lavar, celulares, computadores e sistemas de áudio). Dentre os itens avaliados, os itens de meia vida mais curta são os celulares (2 anos) e computadores (7 anos). ${ }^{100}$

A estruturação de uma logística reversa com dados precários e faltantes é extremamente difícil. ${ }^{40} \mathrm{O}$ ciclo de vida de EEE no país é um desafio frente à grande dispersão territorial dos agentes envolvidos na cadeia da logística reversa e a falta de uma estrutura que dê suporte a essa logística. ${ }^{39} \mathrm{~A}$ principal dificuldade associada à implementação de processos de reciclagem de lixo eletrônico no Brasil é o sistema de coleta, pois sua eficiência depende não apenas da educação/conscientização e cooperação dos consumidores, mas também da cooperação entre geradores de resíduos industriais, distribuidores e governo. Mais de meio milhão de catadores foram recenseados no Brasil e são responsáveis pelo sucesso da coleta de sucata metálica no país. ${ }^{39} \mathrm{O}$ país também possui mais de 2 mil empresas e cooperativas envolvidas em reciclagem e comércio de sucata. Por outro lado, a coleta e a reciclagem de lixo eletrônico ainda são incipientes porque os resíduos eletrônicos não são vistos como valiosos no setor informal. ${ }^{107} \mathrm{O}$ desafio brasileiro é, portanto, organizar um sistema de gestão de lixo eletrônico, incluindo o setor informal, sem negligenciar princípios de gestão ambientalmente saudáveis. ${ }^{39,105,106}$

No país houve um boom generalizado de compra de EEE (celular, computador etc.) devido ao maior acesso das camadas da população a esses bens. É forte a prática de cessão/doação de versões antigas/obsoletas de EEE (segunda mão) pelo país, o que estende a vida útil dos produtos, de modo que o problema do descarte ainda vai atingir um boom num futuro não muito distante da atualidade. ${ }^{18,100}$ Porém, não se dispõe de dados precisos. ${ }^{100} \mathrm{O}$ mercado de EEE recondicionados não é quantificado. ${ }^{39}$ As 
regiões norte e nordeste são as que têm menor penetração de EEE na população. ${ }^{100}$

Segundo estimativas da Fundação Estadual do Ambiente de Minas Gerais (FEAM MG)/EMPA (Suíça), o Brasil gerou em 2009 algo em torno de 4,9 kg EEE habitante ${ }^{-1}$ ano $^{-1}$, sendo 100 mil toneladas de computadores; esse montante passa de 200 mil toneladas, incluindo telefones fixos e celulares e TVs; se acrescentar à essa lista rádios, geladeiras, freezers e máquinas de lavar o montante chega a 679 mil toneladas. ${ }^{39,100}$ A geração de EEE de computadores e celulares foi da ordem de 58 mil toneladas em 2008. ${ }^{100}$ Muitos celulares contêm chumbo acima do permitido pela legislação do Conselho Nacional do Meio Ambiente (CONAMA). ${ }^{108}$ Segundo dados da CEMPRE (Compromisso Empresarial para a Reciclagem), em 2011, 1,9 \% dos RSU era composto por EEE, e a coleta seletiva no país só atingiu $12 \%$ da população em $2010 .{ }^{100}$ Ela também estima que $30 \%$ do mercado interno de eletroeletrônicos é informal, ${ }^{109}$ e uma geração da ordem de $3,77 \mathrm{~kg} \mathrm{hab}^{-1}$ ano $^{-1}$ para TVs geladeiras, freezers, máquinas de lavar sistemas de som, celulares e computadores $\left(0,56 \mathrm{~kg} \mathrm{hab}^{-1} \mathrm{ano}^{-1}\right.$ só para computadores). ${ }^{39}$ A tendência é acentuar esse montante nos próximos anos. ${ }^{18}$

Não há ao que se saiba um fluxo ilegal de EEE no país (entrada e saída). ${ }^{100}$ No mercado formal, a grande maioria da empresas recicladoras reconhecidas pela Associação Brasileira da Indústria Elétrica e Eletrônica (ABINEE) fica no estado de São Paulo, as quais fazem basicamente a triagem e a desmontagem, ${ }^{25}$ exportando itens para reciclagem na Europa, EUA, Singapura, Canadá e Japão, ${ }^{39,100}$ não descartando outras destinações como Índia e China. ${ }^{109}$ Tratam-se de empresas em pequena escala que usam processos simples que desmontam e fazem a separação das frações ricas em plásticos, vidros e metais, mas não há processos de refino de frações (metálicas em especial) de maior complexidade. ${ }^{39}$ Ou seja, além de exportar uma riqueza, pode-se estar exportando um problema face à precariedade da indústria recicladora de alguns desses destinos. A reciclagem total de EEE no Brasil não existe. ${ }^{100}$ Estima-se que só $2 \%$ dos EEE são reciclados no Brasil. ${ }^{100} \mathrm{O}$ que não pode ser exportado/reciclado é descartado em aterros. ${ }^{22}$

A gestão de EEE usados no país é fortemente centrado em programas de coleta de organizações sociais. ${ }^{39}$ Outra vertente são os programas de coleta por iniciativa de fabricantes (devolução de celulares, baterias usadas, tonners, cartuchos etc.). ${ }^{39}$ Uma terceira vertente é preenchida por empresas e cooperativas de catadores. ${ }^{109}$ Com a PNRS e a adequação gradual de todos os atores envolvidos, espera-se um grande desenvolvimento do mercado de reciclagem de EEE no Brasil. ${ }^{100}$ Acredita-se que o país tem um grande potencial de desenvolver a industria de reciclagem de EEE, em todas as suas fases, pois há escala de consumo, mas depende de uma logística reversa eficaz e de uma boa articulação de todos os atores, pessoal qualificado em número suficiente e educação dos cidadãos. ${ }^{39,109}$

As regionalidades do país (face à sua extensão territorial), controles no transporte e o incentivo à implantação de uma indústria recicladora no país são essenciais para que o fluxo de EEE não sofra desvios, repetindo erros observados em outros países. Alguns aspectos precisam ser melhorados, como: a educação ambiental desde o ensino fundamental; a urgência de maior envolvimento dos produtores; a instalação de pontos de coleta de lixo eletrônico nos canais de varejo (ou seja, lojas de varejo, shoppings, farmácias, postos de gasolina, escolas, supermercados entre outros); a criação de políticas governamentais relacionadas a incentivos fiscais; o uso e a adaptação de tecnologias e sistemas para registrar e controlar o retorno do lixo eletrônico; a implementação de procedimentos para controle efetivo pelo Governo para garantir a efetividade da PNRS. ${ }^{110}$ Existem ainda muitos obstáculos para o setor de reciclagem organizado e informal se tornar reconhecido como um ator importante na separação eficiente de materiais e ampliar essas atividades para uma contribuição efetiva para a gestão dos REEE. ${ }^{111}$ Políticas precisam estar 
em vigor para garantir relações de trabalho justas e seguras, onde as comunidades e o meio ambiente se beneficiarão desta nova fonte de matérias-primas. ${ }^{100,111,112}$

\section{Manufatura Reversa dos Equipamentos Eletroeletrônicos}

\subsection{Generalidades}

O resíduo eletroeletrônico é caracteristicamente não homogêneo devido à complexidade de sua composição, ${ }^{60}$ a qual varia de um EEE para outro e mesmo em gerações diferentes de um mesmo EEE. ${ }^{79}$ Por exemplo, observa-se uma tendência à redução do uso de cobre e outros metais preciosos nas gerações mais recentes de EEE. Um estudo na República Tcheca demonstra que em celulares a composição média de modelos fabricados entre 2001-2005 houve uma queda no percentual em massa de metais nobres e tóxicos em sua formulação. ${ }^{53}$ Por isso, o grande desafio é desenvolver tecnologias de manufatura reversa versáteis integrais desse lixo com menor impacto ambiental possível. ${ }^{54}$

A primeira das duas etapas pode ser definida como sendo a triagem, ${ }^{109}$ onde os EEE são coletados, segregados por tipo (monitor, celular etc.), pesados e enviados às linhas de desmontagem dos mesmos. Como cada EEE tem seu formato característico, o mais adequado é conceber um esquema de desmontagem em separado para cada um deles, otimizando o emprego de equipamentos e aumentando a produtividade dos funcionários envolvidos. ${ }^{112}$

Desmontagem se define como um processo organizado de separação de peças de um conjunto que forma um equipamento eletroeletrônico. ${ }^{112}$ Quanto mais especializado, maior é a produtividade. Não são necessários grandes investimentos na preparação dos locais e treinamento das pessoas. Na prática, o trabalho costuma ser intensivo (manual). ${ }^{81} \mathrm{~A}$ quantidade de pessoas depende diretamente da capacidade e do nível de detalhamento da desmontagem. Um estudo para definir as partes que podem ser separadas para reciclagem ou reutilização deve incluir os custos do processo de desmantelamento (equipamentos, depreciações, impostos, salários, insumos, análise dos produtos e valor de mercado destes). ${ }^{113} \mathrm{O}$ custo de desmantelamento é normalmente elevado devido ao grande número de componentes de natureza diferente dentro de cada corrente segregada. ${ }^{113}$ Quanto mais sofisticada a manufatura reversa, maior o investimento em capital, pessoal e espaço físico. ${ }^{112,113} \mathrm{O}$ nível e a capacidade instalada (escala) de desmontagem influencia a rentabilidade do processo.

O foco inicial é a carcaça (Figura 3), que, em geral, é separada sem muita dificuldade dos componentes internos. Outra possibilidade imediata são os fios/cabos elétricos. Os componentes internos podem ser separados em alguns grandes grupos: placas de circuito impresso $(\mathrm{PCl})$, tubos de raios catódicos (CRT), telas planas de monitores de cristal líquido (LCD, liquid crystal display, LED - lighting emission diode), elementos de suporte $\mathrm{e}$ componentes específicos segundo o EEE considerado (como a tela de um scanner, cartuchos de impressoras etc.). Em um estudo publicado no Brasil, ${ }^{114}$ verificou-se que EEE de pequeno porte (calculadoras, mouses, teclados) têm mais de $80 \%$ de seus componentes diretamente recicláveis, percentual esse que cai para $30 \%$ no caso dos monitores CRT. Em qualquer dos casos, esta etapa de desmontagem é primordial para reduzir em um primeiro momento o volume de resíduo eletroeletrônico que efetivamente deve ser gerenciado com a atenção e o cuidado de que precisa. 


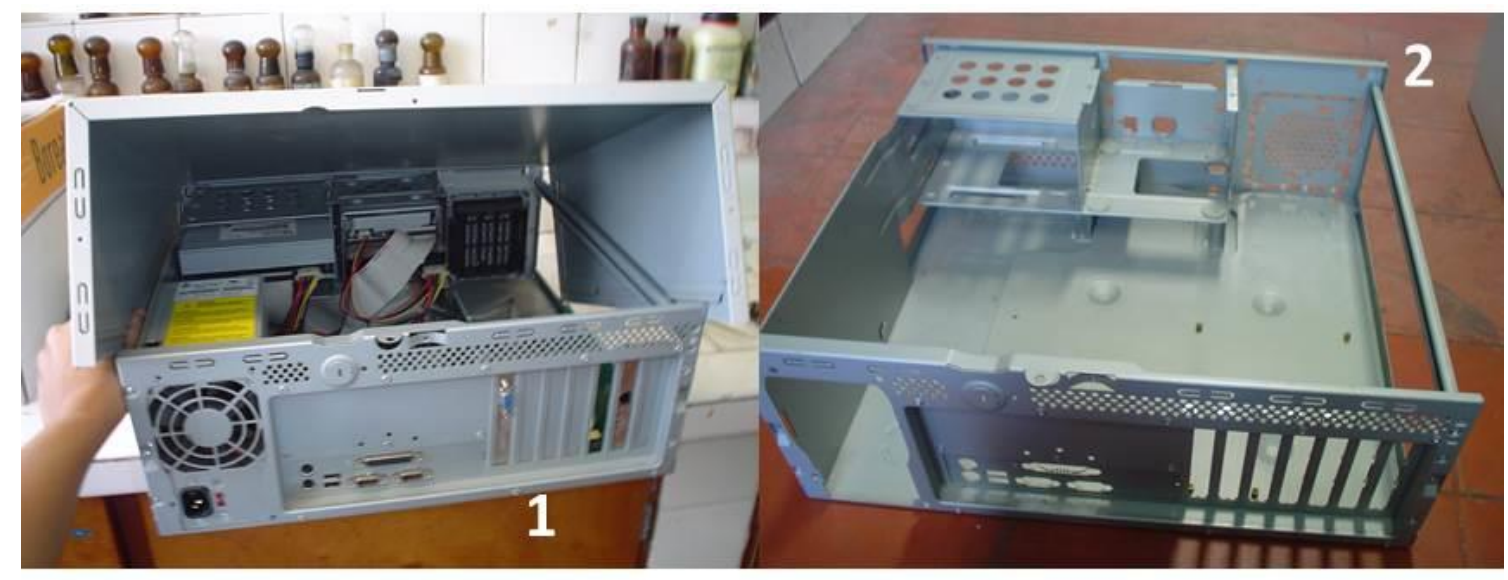

Figura 3: Carcaça metálica de uma "torre" de um computador desktop, feita de aço (2), depois de separada dos demais componentes (1)

Depois de vencida a etapa de desmontagem vem a segunda fase, ${ }^{109}$ que é bem mais delicada: a gestão dos componentes internos. Pela natureza multicomponente dos mesmos, as $\mathrm{PCl}$ e os tubos de CRT são os componentes mais difíceis de serem gerenciados, seguidos pelas telas de LCD. Alguns itens particulares de certos EEE, como os cartuchos e tonners de impressoras, também precisam de cuidados para uma gestão correta dos mesmos. ${ }^{86}$

O ideal é que a manufatura reversa produzisse $100 \%$ de materiais recicláveis, mas diversas limitações de ordem tecnológica ou prática impedem que esse índice seja atingido. Os índices de reciclabilidade que podem ser obtidos variam muito de equipamento para equipamento. Um bom trabalho de manufatura reversa implica em pelo menos um certo grau de divisão de trabalho (especialização das tarefas). Naturalmente, isso eleva os custos com pessoal (salários e encargos), mas também eleva a eficiência e a produtividade da manufatura reversa, com uma menor geração de resíduos finais a serem encaminhados a aterros e maiores obtenções em massa de produtos com valor agregado mais elevado. $\mathrm{O}$ equilíbrio delicado entre maior especialização da manufatura reversa (mais custos, incluindo insumos como energia, e manutenção de equipamentos) e maior eficiência desse procedimento (mais produtos para comercialização e, portanto, de receita) é função de um balanço que defina até onde o empreendimento pode ir sem falir. $O$ treinamento de uma equipe de trabalho em manufatura reversa de equipamentos eletroeletrônicos deve ser bem abrangente, não envolvendo apenas aspectos técnicos, mas também de conscientização e sensibilização da força de trabalho envolvida. O cuidado com a saúde ocupacional permeia todas as fases da manufatura, pois não há sentido em processar um lixo que pode causar impactos ambientais e danos à saúde sem que a segurança individual e coletiva estejam lado a lado com os trabalhadores. A norma da Associação Brasileira de Normas Técnicas (ABNT) 16156 contém requisitos para atividades de manufatura reversa de REEE. ${ }^{115}$ Essa norma estabelece requisitos para a proteção ao meio ambiente e o controle dos riscos de segurança e saúde no trabalho na atividade de manufatura reversa de resíduos eletroeletrônicos.

A manufatura reversa tem início pela descaracterização, isto é, a eliminação de todos os vínculos em relação aos antigos possuidores dos equipamentos. Existem a rigor três correntes obtidas na manufatura reversa: os itens que podem ser diretamente encaminhados às indústrias recicladoras segundo protocolos bem estabelecidos, os itens que podem ser enviados a processos de reciclagem cuja tecnologia não está disponível no país ou é restrita a poucos centros no mundo (eles exigem um processo 
suplementar de segregação, com equipamentos mais caros e complexos e um ambiente controlado), e os itens que devem ser destinados a aterros industriais, para que não causem impactos ambientais, por falta de opção tecnológica de reaproveitamento ou de inexistência de alguma rota de processamento. Tratam-se, na verdade, dos resíduos finais da manufatura reversa.

Muitas das peças dos EEE são multicomponentes - metais, plásticos, resinas etc. - frequentemente unidos de tal forma que, mesmo com toda instrução sobre como se fabricam tais peças, não se tem como fazer a manufatura reversa das mesmas. Isso justifica porque muitas pesquisas acadêmicas e mesmo industriais os moem para que se possam aplicar metodologias de separação baseadas em métodos físicos e químicos para se chegar às frações desejadas.

Uma providência simples, mas de grande importância, a ser tomada nos pontos de triagem, desmonte e processamento é que os EEE e as peças decorrentes de seu desmonte não devem ficar expostos aos agentes naturais (luz solar direta, chuva, vento etc.) para evitar/minimizar reações que liberem componentes dos mesmos e/ou produtos de sua decomposição (caso típico dos retardantes de chama bromados). ${ }^{50,51}$

\subsection{Componentes obtidos após a manufatura reversa}

Placas de circuito impresso (PCI)
Praticamente não há EEE sem que haja $\mathrm{PCl}$ dentro dele. ${ }^{22,39,100,105}$ Existem essencialmente três tipos de $\mathrm{PCl}$ : os de lâmina de cobre simples, camada dupla de cobre e de camadas múltiplas. Elas contêm basicamente três componentes: o cobre, resinas e polímeros orgânicos, e materiais cerâmicos. Em média os estudos da literatura científica mostram que as $\mathrm{PCl}$ de celulares são compostas por 60\% de metais, $\sim 25 \%$ de materiais cerâmicos e $\sim 15$ $\%$ de polímeros, enquanto que as $\mathrm{PCl}$ de computadores contêm $\sim 45 \%$ de metais, 30 $\%$ de polímeros e $\sim 25 \%$ de materiais cerâmicos.

Diante da situação de haver itens prensados, colados e soldados, cerâmicos, poliméricos e metálicos, cuja separação por desmontagem direta (o processo inverso da preparação da $\mathrm{PCl}$ ) é impossível (Figura 4), fazse necessário desenvolver processos que permitam isolar os componentes deste complexo item de um EEE. Necessariamente, esses processos são de desagregação e podem empregar etapas de natureza física ou de natureza química, conforme se empregam ou não reagentes para cumprir a etapa de separação dos componentes. Por esse motivo, as unidades de manufatura reversa de produtos eletroeletrônicos no Brasil não fazem o processamento das $\mathrm{PCl}$, apenas as encaminham para outras unidades recicladoras concebidas para tal. O cuidado maior então está no manuseio das placas pela borda contendo as soldas, pois elas podem produzir arranhões e ferimentos através de suas partes pontudas e afiladas. Devem ser usadas luvas resistentes a rasgos, e as placas devem ser colocadas em recipientes que permitam o manuseio seguro (bigbags, tambores metálicos etc.). 


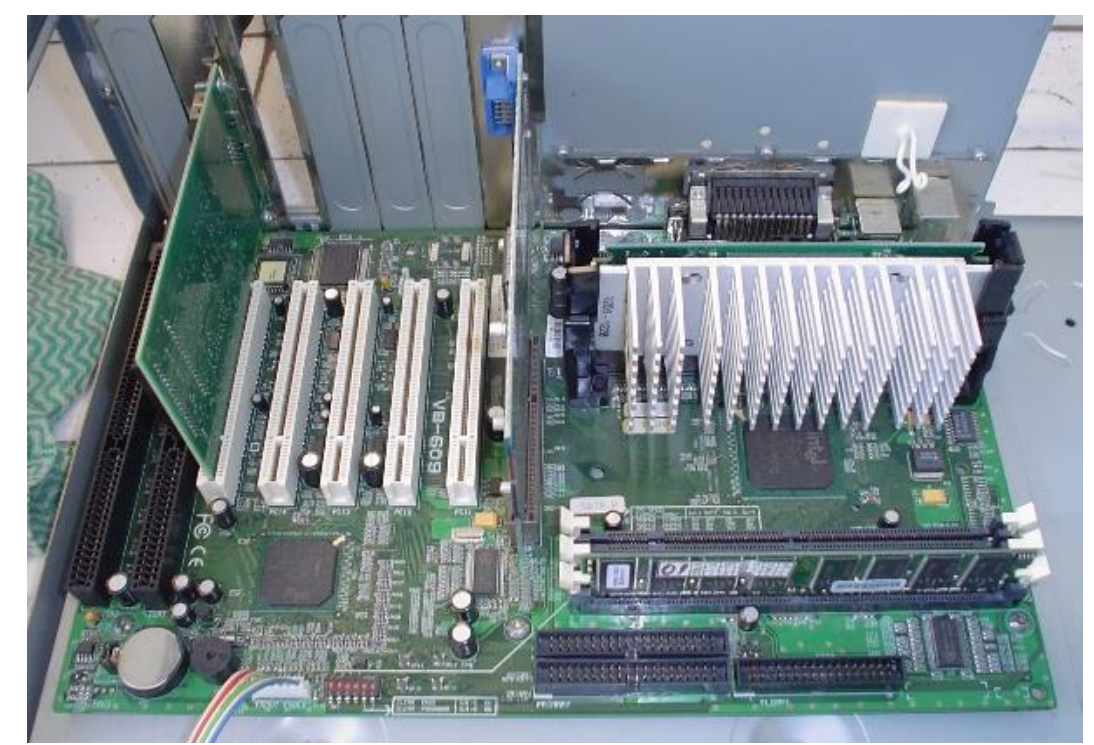

Figura 4: Placa-mãe de um computador desktop, ilustrando a multiplicidade de seus componentes

Tubos de raios catódicos (CRT)

Os monitores de tubos de CRT configuram como uma categoria à parte por possuírem especificidades quanto aos procedimentos de transporte, desmontagem reaproveitamento de materiais. ${ }^{31} \mathrm{O}$ manuseio de tubos de CRT exige muito cuidado porque eles são pesados e são evacuados em seu interior; a quebra pura e simples dos monitores pode causar tanto cortes quanto a pressurização súbita, o que pode ressuspender parte do "pó de fósforo" para o ambiente de trabalho. ${ }^{31,49,83}$ Por isso, o armazenamento e, sobretudo, o transporte dos tubos do local de manufatura reversa para a unidade recicladora é custoso devido ao volume e massa elevados dos mesmos. ${ }^{69}$
Esses tubos são compostos principalmente por materiais vítreos que compõem 80-90 \% da massa (Figura 5) ${ }^{65,69,83} \mathrm{O}$ restante engloba a carcaça, $\mathrm{PCl}$, o chamado "fósforo" e os componentes que produzem os feixes de elétrons (canhão eletrônico). ${ }^{49,65,83}$ Há a possibilidade de reaproveitamento de componentes, peças e partes antes do processamento dos materiais vítreos. ${ }^{31}$

Um tubo de CRT típico é composto pela tela frontal e pelo vidro plumbífero (incluindo a sua parte afilada, chamada "funil"). Na face interna do vidro da tela frontal se encontra o "pó de fósforo". Os dois tipos de vidro devem ser preferencialmente separados porque suas composições são bem distintas. 


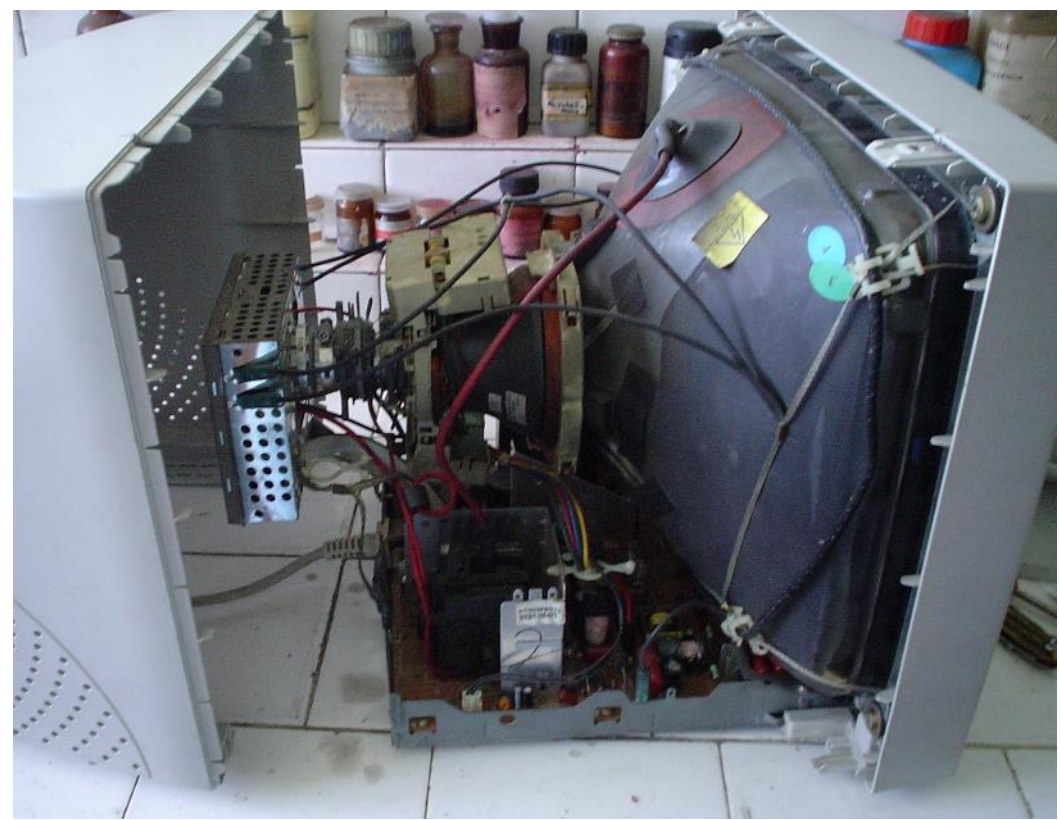

Figura 5: Aspecto de um tubo de CRT de um monitor de computador

O processo se inicia pela quebra controlada do funil, o que leva à pressurização interna do tubo. Em seguida, vem a etapa de separação dos vidros frontal e plumbífero (Figura 6): mediante uma serra (diamantada), um fio eletricamente aquecido a alta temperatura ou laser. A produtividade da abertura por serra é um pouco maior (base de 45 tubos/hora, contra 35 no caso do fio). Mas a técnica com fio (bem como a de laser) não gera raspas ou poeiras vitrificadas, e o corte é perfeito.

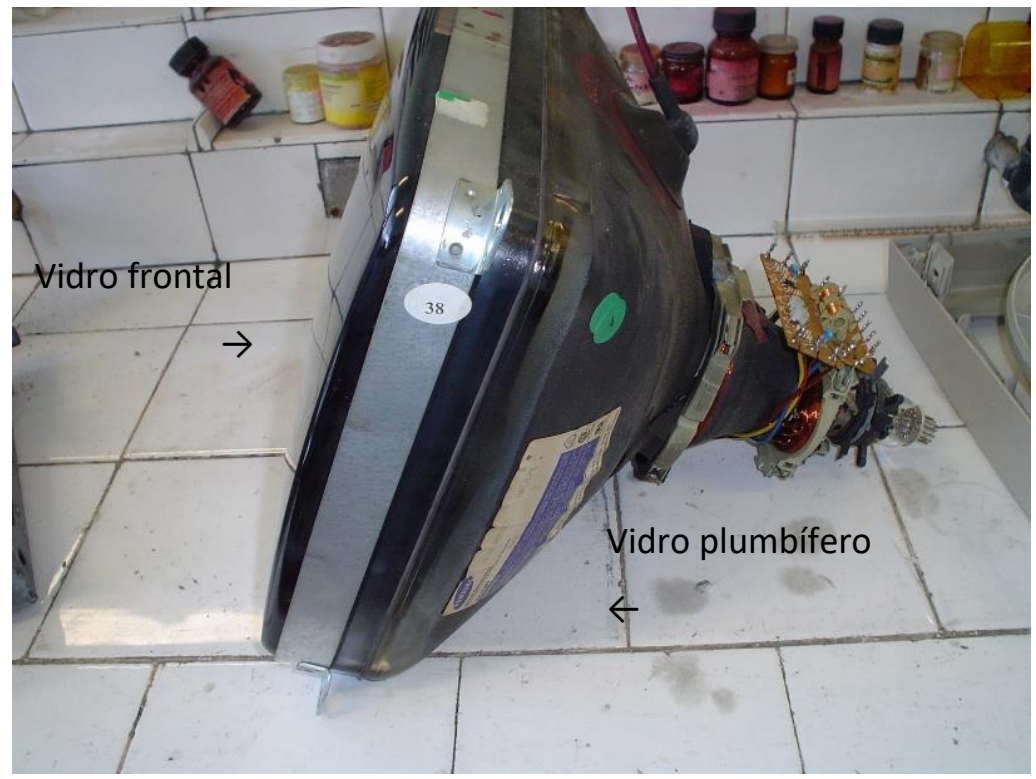

Figura 6: Vidros frontal e plumbífero de um tubo CRT. 
Da mesma forma que as $\mathrm{PCl}$, os tubos de CRT não são normalmente processados nas unidades de manufatura reversa, pois exigem condições especiais de segurança e saúde ocupacionais (ventilação, capelas para aspiração do fósforo, sistema de separação dos vidros), mesmo levando-se em conta que o desmonte desses tubos não envolve processos químicos, e os componentes separados são relativamente poucos.
Dentre os componentes do canhão eletrônico, o chamado "ferrite" ou "ímã cerâmico", material com propriedades eletromagnéticas $\left(\mathrm{SrFe}_{2} \mathrm{O}_{3}\right.$ e/ou $\left.\mathrm{BaFe}_{2} \mathrm{O}_{3}\right)$, normalmente utilizado como núcleo de transformadores elétricos, pode ser utilizado como insumo para coprocessamento. ${ }^{83}$ Os fios de cobre presentes na bobina podem ser diretamente reciclados (Figura 7).

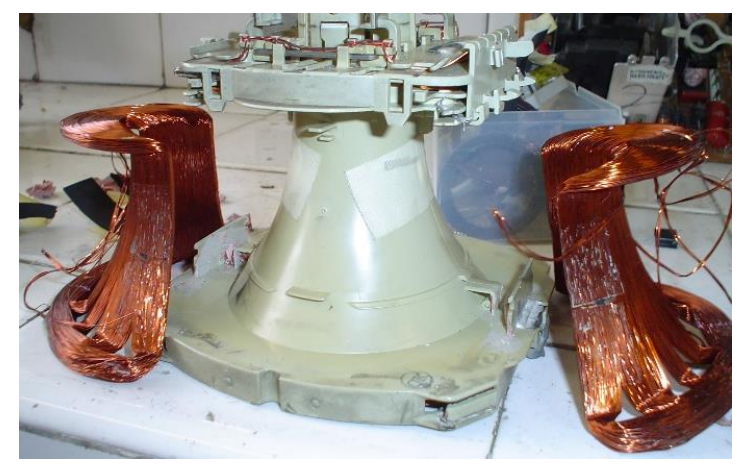

Figura 7: Fios de cobre separados da bobina do canhão eletrônico

Monitores de tela plana (LCD)

Em comparação aos tubos de CRT, a desmontagem de um monitor de LCD é muito mais fácil, rápida e compatível com um ambiente de manufatura reversa. Por isso, ela pode ser feita ainda na etapa de desmontagem inicial (Figura 8).

As telas de LCD são desmontadas manualmente. $\mathrm{A} \mathrm{PCl}$ é menor, bem como a quantidade de fios e cabos. A separação da carcaça plástica dos componentes internos é imediata. Diversas lâminas são superpostas. A dificuldade que aparece nesta fase é a identificação dos polímeros presentes nas lâminas separadas, embora a literatura especifique quais são as seis placas básicas que compõem uma tela de LCD: Filme polarizador na vertical; substrato de vidro com eletrodo ITO (óxido misto de estanho e índio); cristal líquido; substrato de vidro de eletrodo ITO com traçados horizontais para se alinhar com polarizador horizontal; filme polarizador na horizontal; espelho refletivo. 


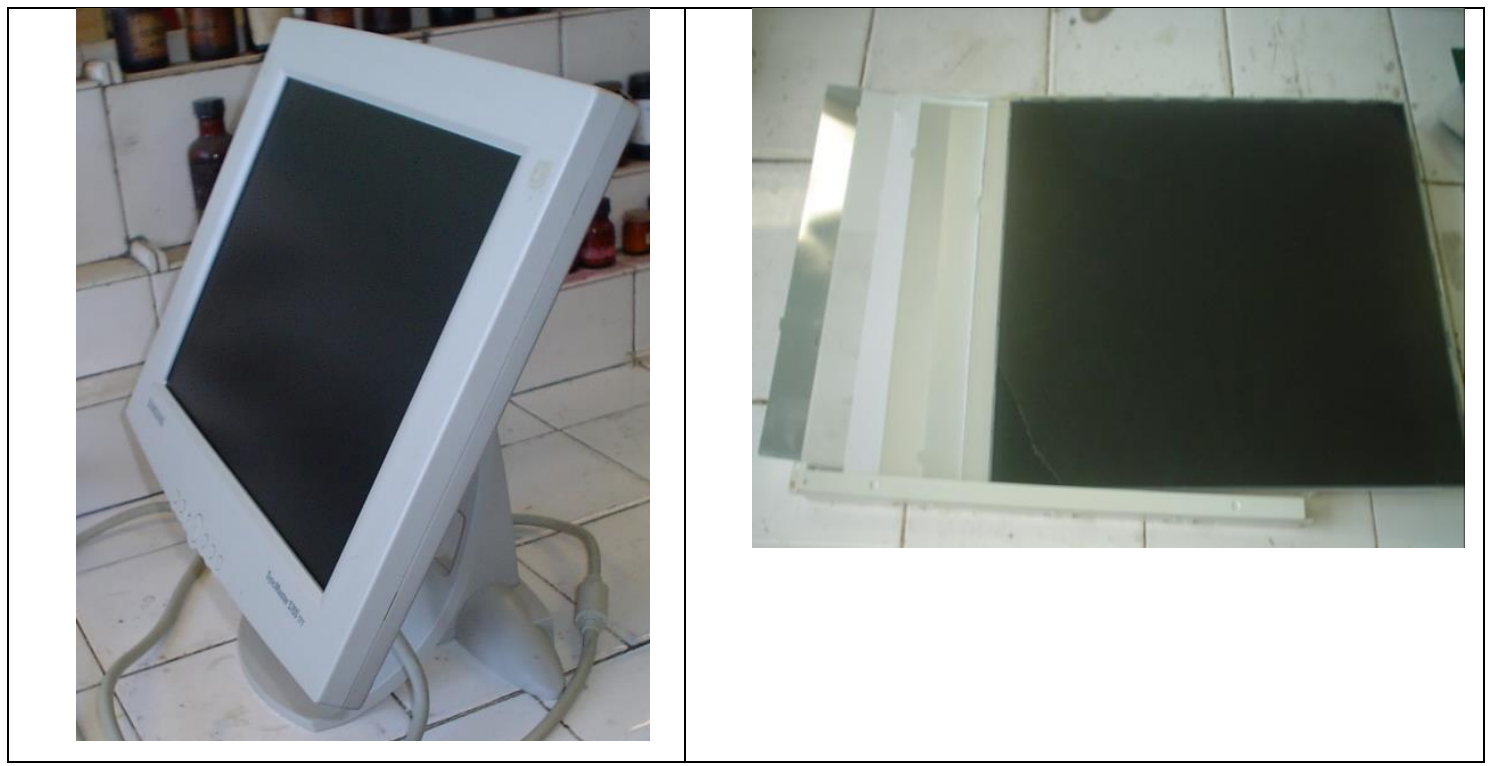

Figura 8: Monitor de LCD: desmontagem mais fácil do que um tubo de CRT. As lâminas internas podem ser facilmente separadas. As lâminas que contêm o óxido ITO têm tonalidade marrom

Fios e cabos elétricos

Fios e cabos não necessitam de maiores cuidados, exceto o de separá-los dos demais eletroeletrônicos, pois são produtos de alto valor agregado e de fácil manejo. ${ }^{31}$ Se o reaproveitamento como tal não for possível, a separação da capa plástica (geralmente, de PVC - poli[cloreto de vinila]) do fio metálico deve ser feita. Esta atividade pode ser encontrada tanto dentro das próprias unidades de manufatura reversa como nos locais para onde os fios/cabos são enviados. 0 principal risco é o corte de dedos e mãos, principalmente quando o processo é manual. O metal geralmente presente é o cobre, ocasionalmente, o alumínio; ambos são de identificação visual fácil.

A queima de cabos e fios para a retirada de metais não é recomendada em razão do potencial tóxico. Eles possuem agentes retardantes de chamas e outras substâncias tóxicas em sua composição e, por este motivo, ao serem queimados podem causar significativos prejuízos à saúde humana e ao meio ambiente. ${ }^{31}$
Módulos como leitoras de $C D$, resfriadores (coolers), discos rígidos e alto-falantes

A gestão desses componentes depende grandemente do grau de desmonte desses módulos. Uma das dificuldades mais comuns é a disponibilidade de ferramentas especiais para fazer um desmonte mais avançado de alguns deles, particularmente os discos rígidos. Se for levada a bom termo, praticamente não sobra resíduos de processo. Os alto-falantes são recicláveis à parte, bem como os ímãs de samário-cobalto ou de neodímio-boro-ferro.

A instrução sobre como se montam tais itens é muito importante para uma manufatura reversa mais produtiva por unidade de tempo. As partes multicomponentes normalmente são uma mistura de metais e plásticos, e a separação entre eles é geralmente difícil (como o caso dos conectores macho e fêmea de mouses, teclados, quer no formato PS2, quer do tipo USB). Existem duas decisões tomadas nesses casos: envio a aterros sanitários ou fragmentação com máquinas cortadoras ou similares para a separação final. 


\subsection{Sobras da manufatura reversa}

Os resíduos descritos a seguir são considerados como não processáveis nas unidades de manufatura reversa e mesmo em unidades externas, seja porque não há tecnologia de reaproveitamento/reciclagem, porque o custo de processamento ainda é demasiado alto para valer a pena, ou porque não há escala para se chegar a um montante economicamente viável. ${ }^{109}$

De um modo geral, peças multicomponentes compõem os resíduos que precisam de uma destinação especial:

a) fósforo dos tubos de raios catódicos. Este deve ser recolhido e destinado a aterro para resíduos perigosos (classe I) para evitar a contaminação do ambiente. ${ }^{31,116}$ Existem estudos e tentativas para destinação a indústrias de materiais cerâmicos e vítreocerâmicos para carga. Os componentes do fósforo são imobilizados na matriz cerâmica;

b) conectores de mouses, teclados, impressoras, partes traseiras de gabinetes etc. A complexa junção de partes plásticas com metálicas dificulta sobremodo a separação dos mesmos mesmo com ferramentas. Uma solução possível é a trituração, tarefa difícil porque as peças são de grande tenacidade;

c) pilhas das placas-mãe: se dentro do disposto da Resolução 401/2008 do CONAMA podem ser dispostas em aterros sanitários licenciados, ${ }^{117}$ embora o ideal fosse o envio a processos de reciclagem, atividade de pequena monta no país;

d) conectores de leitores de CD, drivers de disquete, etc. com a placa-mãe: o melhor é o coprocessamento devido à dificuldade em recuperar os fios pequenos inseridos na camada plástica;

e) adesivos: resíduo comum;

f) lâmpadas de scanner: como contêm mercúrio, devem ser enviadas a empresas que fazem a descontaminação; pode-se negociar a inclusão delas em uma corrente de resíduos de lâmpadas mercuriais; g) peças à base de polímeros como baquelite, resinas epóxi, acrílicos: coprocessamento (Resolução 264/99 do CONAMA), ${ }^{118}$ para aproveitamento de seu conteúdo energético.

h) linhas (barbantes ou de náilon): coprocessamento ou lixo comum se não houver escala suficiente;

i) geradores de raios laser (leitoras de CDs): lixo comum;

j) elásticos e outros materiais à base de borracha: coprocessamento para aproveitamento de seu conteúdo energético.

\subsection{A manufatura reversa no Brasil}

Nenhum empreendimento no Brasil processa quimicamente componentes de produtos eletroeletrônicos. ${ }^{18,103,110,111}$ São aplicados apenas processos físicos na manufatura reversa, o que implica que esta tem apenas a meta de segregação. $O$ que diferencia muito as empresas nesse aspecto é o nível de detalhamento da manufatura, função do instrumental e tecnologia disponíveis para tal. Isso também determina que tipos de produtos eletroeletrônicos podem ser aceitos pelo empreendimento. ${ }^{105-}$ 108

Quando os próprios empreendedores são a mão de obra, isso provavelmente reflete muitas iniciativas de processamento de produtos eletroeletrônicos no Brasil: infraestrutura modesta, improvisada e limitada, e abrangência/capacidade de processamento reduzidas. ${ }^{40,97} \mathrm{~A}$ boa imagem inicial de ajudar o consumidor a se livrar de seu lixo eletrônico pode ocultar danos à saúde e impactos ambientais devido ao processamento improvisado desse resíduo.

Exceto o cobre, os produtos obtidos com a manufatura reversa no país têm valor de mercado baixo. ${ }^{107,110}$ Só a receita obtida com a venda desses materiais (à qual se podem adicionar receitas ocasionais como no caso da venda de computadores re-manufaturados) não cobre os custos da gestão dos resíduos 
eletroeletrônicos. ${ }^{40,111}$ Esse ponto tende a desestimular iniciativas empreendedoras com esse lixo, ou levar à insolvência iniciativas baseadas em uma visão parcial do problema, sem se atentar para os seus percalços. A falta de um incentivo direto à reciclagem no país é outro entrave para que a economicidade de um empreendimento de gestão dos REEE no Brasil seja efetivamente viável. ${ }^{105-108,110,111} \mathrm{Se}$ houvesse uma real política de incentivos à reciclagem desse e de outros tipos de lixo tecnológico no Brasil, os produtos obtidos na manufatura reversa enviados para reciclagem poderiam ser isentos de impostos como o ICMS (Imposto sobre a Circulação de Mercadorias e Serviços), o que daria maior competitividade aos negócios com resíduos no país. Devido a esse quadro, taxas de coleta e transporte dos produtos eletroeletrônicos são cobradas dos consumidores para que se obtenha uma receita adicional para fazer frente aos custos da manufatura reversa. ${ }^{100,102,103,111}$

\section{Processamento de Componentes dos Equipamentos Eletroeletrônicos}

\subsection{Introdução}

O processamento correto do resíduo eletroeletrônico o valoriza como fonte alternativa ou secundária de diversos metais, evita a liberação daqueles tóxicos ao ambiente, e ainda reduz as emissões de gases do efeito estufa comparado à obtenção desses metais a partir de fontes primárias. ${ }^{62,94}$ A recuperação do cobre e de plásticos pode economizar até $80 \%$ da energia usada a partir do processamento de fontes naturais. ${ }^{52} \mathrm{~A}$ extração de metais de fontes primárias é cada vez mais trabalhosa e custosa, os teores são cada vez menores, e as reservas economicamente viáveis se concentram em poucos locais (por exemplo, África do Sul, 89 $\%$ dos metais platínicos). ${ }^{30}$ A mineração intensiva para obtenção de metais e não metais de suas fontes primárias é um dos aspectos mais marcantes do Antropoceno. ${ }^{19,26,29}$

A reciclagem pode ser definida como uma opção de recuperação de insumos para produzir novos materiais a partir de resíduos. Contudo, deve-se enfatizar que, se propostas de tecnologias ambientalmente adequadas de reciclagem podem ajudar a resolver problemas antigos, elas também têm que lidar com novos: energia eólica, carro elétrico, células a combustível, lâmpadas fluorescentes compactas etc. exigem metais escassos e preciosos para sua produção, cujas reservas hoje conhecidas tendem a esgotar-se em curto prazo. ${ }^{30}$

\subsection{Placas de circuito impresso}

As $\mathrm{PCl}$ são consideradas o componente dos REEE mais difícil de ser reciclado. ${ }^{22,39,100,105,119,120}$ As $\mathrm{PCl}$ modernas podem conter até 60 elementos diferentes. ${ }^{120}$ Estes elementos podem ser classificados como metais preciosos ( $\mathrm{Ag}, \mathrm{Au}, \mathrm{Pd}, \mathrm{Pt}, \mathrm{Rh}, \mathrm{Ir}$, $\mathrm{Os}, \mathrm{Ru})$, metais comuns ( $\mathrm{Cu}, \mathrm{Ni}, \mathrm{Zn}, \mathrm{Cr}, \mathrm{Al}, \mathrm{Sn}$, $\mathrm{Fe})$, metais perigosos $(\mathrm{Hg}, \mathrm{Cd}, \mathrm{Be}, \mathrm{Pb})$ e elementos escassos ou traços (In, Te, Ga, Se, $\mathrm{Ta}, \mathrm{Ge}) \cdot{ }^{12,25,108} \mathrm{O}$ cobre é largamente o metal mais abundante, seguido de zinco, ferro, níquel, alumínio, chumbo e estanho. ${ }^{121,122}$ Por outro lado, verifica-se uma tendência à redução do tamanho e ao aumento da complexidade das $\mathrm{PCl}$ e com variação constante da quantidade e tipos de componentes ao longo das gerações. ${ }^{44,120}$ Estudos de caracterização de $\mathrm{PCl}$ de celulares e computadores mostram que os metais compõem 45-63 \% da massa; o restante é composto por materiais cerâmicos (24-28 \%) e polímeros (13-27\%). ${ }^{120}$

As $\mathrm{PCl}$ são a porção mais economicamente atraente dos EEE. ${ }^{7,12,13,25,42,70,123-125} \mathrm{Em}$ particular, as $\mathrm{PCl}$ de celulares são muito ricas em metais nobres (Figura 9), ${ }^{108}$ superando em 
muito os teores encontrados em fontes

naturais.

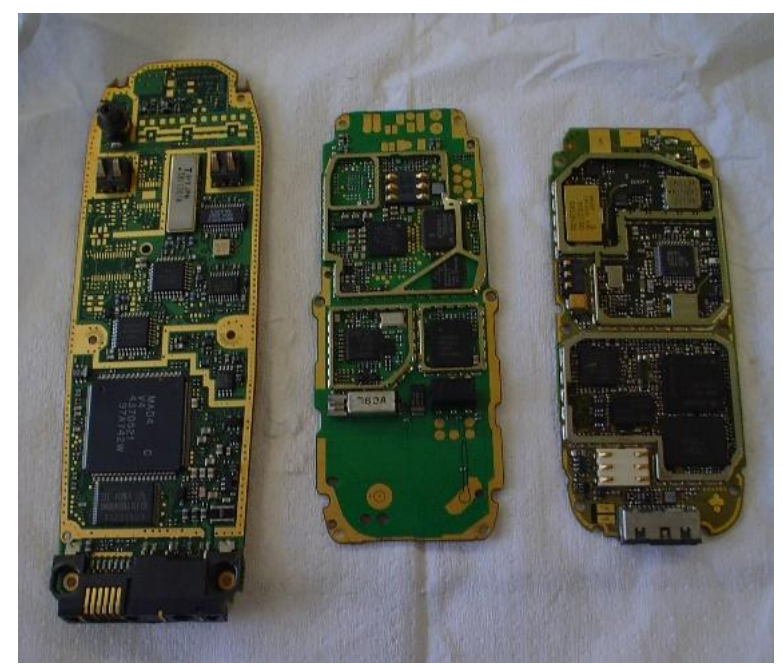

Figura 9: $\mathrm{PCl}$ de telefones celulares são mais ricas em ouro que as $\mathrm{PCl}$ de computadores

O mercado para a fração não metálica aumentará a rentabilidade do processamento das placas de circuito impresso (PCl), hoje muito focada nos metais. ${ }^{5,119}$ Por outro lado, a gestão das $\mathrm{PCl}$ deve levar simultaneamente em conta os elementos valiosos e os tóxicos. ${ }^{79}$

O entendimento de como se monta uma $\mathrm{PCl}$ permite ver porque processá-lo é uma tarefa desafiadora para a área de pesquisa e desenvolvimento (P\&D). Em suma, sobre a base da placa, chamada laminado, que pode ser composta de polímeros e resinas orgânicas ou destes juntamente com fibras e materiais cerâmicos (silicatos/aluminossilicatos de cálcio, potássio, bário etc.), apõe-se uma camada de cobre em cada um dos dois lados da placa, sobre a qual se fixam os demais componentes (capacitores, processadores, etc.). Esses componentes são basicamente soldados com ligas eutéticas (misturas de metais que têm ponto de fusão constante, geralmente à base de chumbo e estanho). Por fim, a $\mathrm{PCl}$ pronta é coberta por uma fina camada de resina incolor ou com algum corante (comumente verde) contendo retardantes de chama bromados, que visam retardar a propagação de chamas em caso de princípio de incêndio, tratamento esse outrora conhecido como ignifugação. ${ }^{12,121,123,126}$
Os processos de reciclagem de $\mathrm{PCl}$ de $\mathrm{EEE}$ podem ser classificados como: ${ }^{97}$ low-tech, baixo aproveitamento, alta geração de resíduos poluentes, foco em apenas alguns itens, trabalho manual intensivo e uso de técnicas grosseiras (queima, serragem, calcinação); medium-tech, rendimentos moderados, foco em metais nobres, uso de lixívias químicas, altamente poluentes e impactantes sobre o ambiente e danosas à saúde; high-tech, altos rendimentos, baixa geração de poluentes, emprego de técnicas metalúrgicas, pouco trabalho manual, controle ambiental de emissões, tecnologia de ponta. Mas os investimentos são muito altos, da ordem de um bilhão de dólares norteamericanos. ${ }^{97,123} \mathrm{E}$ a escala é fundamental para que valha a pena. Os processos de reciclagem em países desenvolvidos passam pela parceria entre academia e indústrias, enquanto que em países da África e da Ásia as ações são isoladas e não coordenadas. Os sistemas de reciclagem de EEE e seus componentes nos países desenvolvidos são altamente mecanizados, complexos (multietapas), maduros e em princípio eficientes, mas são de alto investimento e de alto custo operacional. Grosso modo, a reciclagem de EEE em países desenvolvidos se baseia na obtenção de concentrados de 
metais, plásticos etc., ${ }^{34,39}$ e o emprego de processos piro-hidrometalúrgicos para recuperar elementos de interesse. ${ }^{34,39}$ Contudo, nem sempre a eficiência em termos de tratamento das emissões é atestada ou certificada. ${ }^{25} \mathrm{Em}$ países africanos e asiáticos os processos são artesanais em escala rudimentar, além de serem basicamente informais, e sem controle do ambiente e da saúde ocupacional, cujas consequências já foram descritas anteriormente nesta revisão, e contribuem para caracterizar o Antropoceno. ${ }^{39}$ A legislação falha, a pressão por produtos de segunda mão e o subemprego favorecem essas práticas. ${ }^{34,96}$ Os EEE são tratados para recuperar apenas os componentes mais fáceis ou valiosos. ${ }^{98}$

Separação da fração metálica da não metálica

Hoje, técnicas físicas são amplamente utilizadas para separar frações metálicas de não metálicas das $\mathrm{PCl}$ : trituração, moagem, separação por densidade, magnética, gravidade, eletrostática. ${ }^{6,52,81,108,119,120,127,128}$ A moagem é a etapa prévia mais usual. ${ }^{129}$ Os aspectos básicos envolvidos nessa fase são: enriquecimento de componentes metálicos e não-metálicos em frações distintas, e recuperação de metais preciosos ou outros componentes específicos. ${ }^{130,131}$ Porém, ela produz poeiras e material particulado (finos), e mesmo gases e vapores por conta da tenacidade e resistência das $\mathrm{PCl}$ à quebra. ${ }^{43,81}$

Os finos, além de serem tóxicos, podem representar perdas de metais preciosos, ${ }^{81}$ como o ouro ${ }^{25}$ e o paládio. ${ }^{52}$ Tamanhos de partícula de $1 \mathrm{~mm}$ ou menos facilitam a liberação dos metais dos polímeros/materiais cerâmicos, mas os processos exigem água para não haver perdas de finos, o que exige separação, secagem e tratamento da água e do lodo produzidos..$^{52} \mathrm{O}$ sistema de moagem deve prover homogeneidade das partículas para evitar que a recuperação das partes metálicas seja desigual. ${ }^{132,133} \mathrm{~A}$ moagem por bolas é melhor que por discos por produzir partículas mais uniformes em termos de composição. ${ }^{134} \mathrm{Em}$ qualquer caso, o sistema de pulverização deve também ser um sistema fechado para confinar as poeiras produzidas em seu interior. Uma alternativa à moagem clássica é cortar em pedaços pequenos, sem moagem, mas os investimentos em equipamentos são bem maiores. ${ }^{133}$

A combustão (queima) de $\mathrm{PCl}$ contendo retardantes organobromados exige temperaturas muito elevadas (800-1400 ㅇ) e um excesso de ar até $90 \%$ acima do estequiométrico. ${ }^{60}$ É comum que as fibras de vidro presentes nas placas entrem em estado de fusão, protegendo os metais de uma oxidação profunda e evitando a própria escorificação dos mesmos. ${ }^{59}$ De modo geral, é altamente desaconselhável que as $\mathrm{PCl}$ sejam processadas dessa forma por conta do elevado consumo energético, das condições severas da queima e da dificuldade de processar o resíduo formado, que contém a fração metálica originalmente presente. Outro argumento é que a pirólise das $\mathrm{PCl}$ reduz o rendimento da dissolução dos metais nobres por via hidrometalúrgica devido à formação de ligas mais resistentes a ataques químicos. ${ }^{128,129}$

Processamento das $\mathrm{PCl}$ para eliminação dos retardantes de chama bromados

No processamento das $\mathrm{PCl}$ os retardantes devem ser removidos porque atrapalham a recuperação dos metais presentes e, conforme visto anteriormente, a queima das $\mathrm{PCl}$ pode formar dioxinas e furanos bromados altamente tóxicos. ${ }^{61}$ Os melhores métodos envolvem o uso de fluidos supercríticos (como o $\mathrm{CO}_{2}$ ) e solventes orgânicos de baixo ponto de ebulição (acetona, metanol, tolueno, clorofórmio $+\mathrm{n}$-hexano (1:1)). ${ }^{61,135}$ Essa solubilização deve atingir tanto as moléculas de retardante polares como as não-polares. ${ }^{135}$ Retardantes de chama bromados podem ser também rapidamente dissolvidos em líquidos iônicos, considerados solventes verdes nãoaquosos. ${ }^{127}$ 
Fluidos supercríticos podem também degradar retardantes de chama bromados. ${ }^{136}$ Por exemplo, água, metanol, acetona, isopropanol em temperaturas acima de 300400 ㄷ degradam os retardantes de chama tanto na superfície como no seio das $\mathrm{PCl}$ ( $>95$ $\%$ eficiência). $O$ isopropanol é considerado o melhor deles, inclusive promovendo despolimerizações, formando elevadas quantidades de óleo contendo bromo, o qual é removido por lavagem com solução de $\mathrm{KOH} .{ }^{137} \mathrm{O}$ metanol é capaz de remover um dos retardantes mais usados, tetrabromobisfenol $A$, com pouco efeito sobre a fração polimérica dos EEE. ${ }^{51}$

É possível fazer a pirólise das $\mathrm{PCl}$ desde que na presença de óxidos de metais de transição (zinco, ferro, cobre - $\mathrm{ZnO}, \mathrm{Fe}_{2} \mathrm{O}_{3}, \mathrm{CuO}$ ) ou ainda lantânio $\left(\mathrm{La}_{2} \mathrm{O}_{3}\right)$ e cálcio $(\mathrm{CaO}) \cdot{ }^{138} \mathrm{~A}$ finalidade destes óxidos é fixar o bromo como brometo ou oxibrometo inorgânico, evitando a liberação de $\mathrm{HBr}$, bromo $\left(\mathrm{Br}_{2}\right)$ e compostos organobromados. A melhor forma de descartar o bromo no meio ambiente é na forma de brometo inorgânico, ${ }^{33}$ que é a forma como se encontra basicamente na natureza por exemplo, na água do mar (em torno de 65 $\left.\mathrm{mg} \mathrm{L}^{-1}\right) .{ }^{49}$ Os primeiros resultados indicam que os melhores óxidos foram $\mathrm{ZnO}$ e $\mathrm{La}_{2} \mathrm{O}_{3}$ (mais de $80 \%$ de redução da formação de $\mathrm{HBr}$ e organobromados em relação à pirólise sem óxido), outros óxidos são reduzidos a metal $(\mathrm{Fe}, \mathrm{Cu})$, e $\mathrm{CaO}$ foi pouco ativo apesar de ser um óxido básico. ${ }^{138} \mathrm{Em}$ outro estudo, ${ }^{76}$ a pirólise na presença de carbonato de cálcio $\left(\mathrm{CaCO}_{3}\right)$ fixou o bromo como brometo. O cobre não foi praticamente atacado e a fração polimérica se torna quebradiça, sendo mais facilmente separada da fração metálica.

Em outro estudo de pirólise de $\mathrm{PCl}$ (cuja solda foi previamente removida por aquecimento), o processo a seco (sem oxigênio) teve rendimento de $20-27 \%$ de óleo (fenóis e fenóis substituídos, principalmente) e $3 \%$ de gás $\left(\mathrm{CO}, \mathrm{CO}_{2}, \mathrm{CH}_{4}\right.$ e $\left.\mathrm{H}_{2}\right)$. Os resíduos de pirólise contêm metais, fibras de vidro e outros materiais inorgânicos, basicamente cerâmicos. A pirólise sem $\mathrm{O}_{2}$ gera produtos líquidos ou gasosos orgânicos que podem ser usados como combustível, uma vez atestado que o bromo esteja ausente. No vácuo, a temperatura desse processo é mais baixa, o que minimiza reações secundárias que formam polímeros. ${ }^{127}$

Processamento da fração não-metálica de $\mathrm{PCl}$

A reciclagem da fração não-metálica de $\mathrm{PCl}$ interessa econômica e estrategicamente a países dependentes de petróleo e produtos petroquímicos..$^{72,139} \mathrm{~A}$ gigantesca produção mundial de plásticos (260 milhões de toneladas em 2009) impulsiona políticas de coleta e destinação final apropriadas, e a reciclagem de todas as formas vem sendo pesquisada. ${ }^{140}$ Porém, as pesquisas com a fração não-metálica são menos numerosas do que com a fração metálica devido ao baixo valor agregado da primeira e da possível presença de substâncias tóxicas. ${ }^{15}$

Um requisito indispensável é a identificação do tipo de polímero presente porque nem todos eles podem ser reciclados juntos. Esse requisito não vale apenas para os polímeros das $\mathrm{PCl}$, mas inclui igualmente carcaças, encapamentos de fios e peças de sustentação interna. No Brasil a referência é a Norma ABNT NBR 13.230 para a identificação dos principais tipos de polímeros usados comercialmente. ${ }^{141}$ Pode haver até 15 tipos de polímeros diferentes na fração não-metálica de uma $\mathrm{PCl}^{72}$

Num estudo feito com resíduos de EEE (incluindo as carcaças), ${ }^{72}$ poliestireno, ABS (copolímero acroleína-butadieno-estireno), policarbonatos, poliestireno de alto impacto e polipropileno são os polímeros mais comuns. Em outro estudo, os polímeros mais frequentes são polietileno de alto impacto, ABS e polipropileno..$^{79} 55 \%$ dos polímeros de EEE são $A B S$ + poliestireno de alto impacto. ${ }^{72}$ Isso significa que a maioria deles é do tipo termoplástico. O tipo e a geração do EEE considerado pode mudar a quantidade relativa dos diversos polímeros, até mesmo suprimindo alguns e aparecendo outros. ${ }^{79}$ Os contaminantes que colocam maiores 
dificuldades para o processamento são os aditivos de cor. A identificação nem sempre padronizada e a não indicação da ausência ou presença de retardantes de chama bromados coloca grandes desafios para a separação e a reciclagem de materiais poliméricos de EEE. ${ }^{72}$

A separação da fração metálica da nãometálica envolve basicamente diferenças de massa específica (densidade) mediante o emprego de solventes aquosos e orgânicos de diferentes massas específicas (densidades) e de fluxos de ar ascendente em equipamentos de separação em batelada ou contínuo. ${ }^{85,113,140,142}$ O custo normalmente é elevado devido a esses equipamentos. ${ }^{113}$ Os metais são bem mais densos (em geral, acima de $5 \mathrm{~g} \mathrm{~cm}^{-3}$ ) que os polímeros (entre 0,9 e 1,5 $\mathrm{g} \mathrm{cm}^{-3}$ ). Essa grande diferença explica porque os fluxos de ar ascendente são muito bons para essa tarefa, e muita pesquisa e desenvolvimento vem sendo feito para conceber concentradores de frações nãometálica e metálica de $\mathrm{PCl}$ após moagem: adoção de chicanas, fluxos em zigue-zague, reciclos etc. $\mathrm{O}$ problema reside no tamanho médio das partículas metálicas, que se forem muito pequenas, acabam sendo carreadas pelo fluxo de ar, indo parar na fração nãometálica, o que significa perda de metais preciosos e contaminação da fração não metálica. Por isso, deve haver um compromisso entre as etapas de moagem das $\mathrm{PCl}$ e de separação das frações metálica e nãometálica por fluxos de ar. Cada caso é um caso, pois a composição e tipo da $\mathrm{PCl}$ determinará o ponto ótimo para conciliar estes dois processos. Não há, sem moagem prévia ou processo similar (desagregação), meios de separar fisicamente metais de polímeros (e materiais cerâmicos) devido ao modo como as $\mathrm{PCl}$ são produzidas. ${ }^{113,140}$

Uma vez separada a fração não-metálica da metálica, a primeira possibilidade, que é bem intuitiva, é processar todos os tipos de polímeros juntos, como acontece na recuperação energética (coprocessamento), para evitar etapas de separação desses polímeros. ${ }^{143} \mathrm{~A}$ grande desvantagem desse procedimento é que a fração não-metálica como um todo normalmente possui valor agregado baixo. Por esse mesmo motivo, ela seve basicamente somente para aplicações do tipo material de enchimento, tintas, pavimentação etc. No caso de uma separação malsucedida, metais nobres podem ser perdidos nessa fração. ${ }^{81}$ Outros empregos propostos para a fração não-metálica de $\mathrm{PCl}$ são: aditivos ao cimento (desde que sem bromo), massa asfáltica, compósitos e peças pré-moldadas. ${ }^{136}$

Soluções aquosas e orgânicas de diferentes massas específicas (entre 0,8 e $1,5 \mathrm{~g} \mathrm{~cm}^{-3}$ ) são empregadas para diferenciar os polímeros entre eles, conforme a densidade destes. Os polímeros mais densos que o líquido afundam, enquanto que os menos densos vão para a superfície. ${ }^{144}$ Como não há reação química ou solubilização entre os materiais plásticos e os solventes, uma vez feita a separação pode-se filtrar o material que boia na superfície e drenar o líquido para separá-lo do material que não flutuou (o mais denso). Este é mergulhado em outro líquido de massa específica diferente do anterior. $O$ processo se faz do líquido mais denso para o menos denso. Os líquidos podem ser reutilizados, havendo apenas a necessidade de repor as perdas por evaporação e adsorção nos polímeros. Estes devem ser lavados com água depois de separados, o que leva à geração de efluentes aquosos contendo componentes dos líquidos utilizados na separação dos polímeros e à necessidade de gerenciá-los.

Dentre os aditivos encontrados nos polímeros, os retardantes de chama bromados reduzem a faixa de fusão dos mesmos, e por isso dificultam a reciclagem mecânica deste, ${ }^{139}$ impedem a sua queima em cimenteiras (coprocessamento) e a reutilização na fabricação de novas peças plásticas. $^{72}$ Madeiras e borrachas atreladas aos polímeros são um problema comum, normalmente superado quando da separação por diferença de densidade, ${ }^{144}$ mas implica em etapas adicionais. ${ }^{74} \mathrm{O}$ melhor nesse caso é segregar estes materiais no momento da desmontagem do EEE. ${ }^{72,74}$ A presença de elementos como cádmio, mercúrio, cromo 
hexavalente, estanho e chumbo acima de $1.000 \mathrm{ppm}\left(\mathrm{mg} \mathrm{kg}^{-1}\right)$ impede a reciclagem dos polímeros (100 ppm para o cádmio)..$^{72}$ Metais em geral catalisam a degradação destes nos processos de reciclagem. ${ }^{72,73} \mathrm{O}$ problema é bem característico para o ferro, metal comum na fração metálica de $\mathrm{PCl}$. Isso explica porque a separação das frações metálica e nãometálica deve ser feita com muito critério para minimizar os problemas quando do processamento desta última.

A queima simples (recuperação da energia) se aplica a materiais contendo resinas epóxi, retardantes de chama (sem bromo), vidros, fibras e agentes de ligações cruzadas, aceleradores de formação de ligações cruzadas entre outros, mas o controle das emissões deve ser muito rígido, sendo extremamente questionável do ponto de vista ambiental. ${ }^{136,144}$ Estudos vêm tentando inserir a reciclagem química, através da decomposição (despolimerização) das ligações cruzadas dos polímeros por meio de soluções aquosas ou solventes orgânicos apropriados, mas ainda não se têm resultados conclusivos. $^{136}$

Existe uma linha de pesquisa, possivelmente promissora, que busca direcionar a fração não-metálica ou mesmo a $\mathrm{PCl}$ inteira para processos de geração de gás hidrogênio $\left(\mathrm{H}_{2}\right)$ mediante fusão na presença de carbonatos alcalinos em estado de fusão, com ou sem a presença de outros metais, ${ }^{78}$ ou ainda pirólise ${ }^{125} \mathrm{em}$ um ou dois estágios na presença de catalisadores como zeólitas ou $\mathrm{Ni} / \mathrm{Al}_{2} \mathrm{O}_{3}$ (alumina), ${ }^{136,143}$ o qual aumentam a geração de $\mathrm{H}_{2}$, ou micro-ondas. ${ }^{145}$ Poliestireno de alto impacto produz mais hidrogênio que ABS e demais polímeros. ${ }^{143}$ Esta tecnologia se enquadra nas exigências da legislação européia de reciclar componentes de EEE. ${ }^{143}$ É preciso controlar a qualidade do óleo obtido (sem bromo, por exemplo) pois os produtos de pirólise tendem a ter valor agregado baixo. ${ }^{136}$

Para que os polímeros de $\mathrm{PCl}$ sejam fonte de energia ( $\mathrm{H}_{2}$ e óleo), a desalogenação deve ocorrer nos processos de tratamento desses materiais. Compostos organo-halogenados, altamente tóxicos e poluentes ambientais, podem aparecer nos óleos de pirólise e nos gases. ${ }^{73}$ Pesquisas mostram que também pode-se fazer a desalogenação depois ou simultaneamente à pirólise. A pirólise a baixa temperatura libera $\mathrm{HX}(\mathrm{X}=\mathrm{Cl}, \mathrm{Br})$, separandoo dos produtos de decomposição da matriz polimérica, antes da segunda etapa de pirólise a alta temperatura. $O$ processo direto e simultâneo é o mais usado. Cloro e bromo são fixados como haletos inorgânicos. A desalogenação após a pirólise eleva o custo do processo como um todo. ${ }^{32,136}$ Se presente em retardantes de chama, o antimônio interfere no processo de desalogenação, mas pode ser recuperado na purificação do óleo de pirólise. ${ }^{32}$

\section{Processamento da fração metálica de $\mathrm{PCl}$}

A recuperação de metais de $\mathrm{PCl}$ tem fortes apelos econômico e ambiental face à pressão que esses produtos de alta tecnologia exercem sobre o mercado produtor de certos metais. ${ }^{146-148}$ A indústria de produtos eletroeletrônicos está entre os maiores consumidores desses metais, especialmente prata e cobre. ${ }^{12,148}$ Os EEE consomem $15 \%$ do paládio, $80 \%$ do índio, $15 \%$ do cobalto e praticamente $100 \%$ do rutênio produzidos no mundo (dados de 2010). ${ }^{62}$ A fabricação de celulares consome $3 \%$ do ouro, $3 \%$ da prata, $13 \%$ do paládio e $15 \%$ do cobalto produzidos mundialmente. ${ }^{44,146}$ Dados de 2008 apontam que, para a produção de 300 milhões de laptops, consumiram-se $150 \mathrm{mil}$ t de cobre, $9100 \mathrm{t}$ de cobalto (baterias de íon-lítio), $300 \mathrm{t}$ de prata, $66 \mathrm{t}$ de ouro e $24 \mathrm{t}$ de paládio. ${ }^{30} \mathrm{Em}$ 2016, cerca de 180 milhões de laptops produzidos consumiram 100 mil t de cobre, 8 mil t de cobalto (baterias de íon-lítio), $220 \mathrm{t}$ de prata, $40 \mathrm{t}$ de ouro e $12 \mathrm{t}$ de paládio. ${ }^{149}$

As $\mathrm{PCl}$ contêm quantidades importantes de metais valiosos, ${ }^{127}$ até 40 vezes a concentração de cobre, prata, ouro e paládio em seus minérios. ${ }^{7-10,126,147} \mathrm{O}$ alto conteúdo de metais comuns e preciosos nas $\mathrm{PCl}$ faz delas uma fonte secundária em potencial para recuperação de metais. ${ }^{10,13} \mathrm{O}$ valor econômico das $\mathrm{PCl}$ é concentrado em metais preciosos, 
seguido de cobre, estanho, alumínio, chumbo, zinco e níquel. ${ }^{122,150,151}$ No entanto, a junção de materiais orgânicos e cerâmicos, metais e fibras de vidro em um volume tão pequeno ${ }^{43,70,152}$ faz com que o processamento das $\mathrm{PCl}$ seja uma tarefa desafiadora ${ }^{8}$ e a principal barreira na recuperação de metais. ${ }^{13,24,124}$ Cerca de $30 \%$ do ouro, $20 \%$ do paládio e $12 \%$ da prata vêm de fontes secundárias. ${ }^{10,148}$ Apenas cerca de $15 \%$ das sucatas de PCB são submetidas a algum tipo de reciclagem. ${ }^{126}$ Os elementos críticos num curto e médio prazo por conta dos EEE são: prata, ouro, bismuto, cobalto, cobre, paládio, antimônio, estanho, selênio, telúrio, índio e chumbo. ${ }^{33,34,43,44}$

Há poucas plantas em operação no mundo (Bélgica, Alemanha, Japão e Suécia), mas as tecnologias atuais não recuperam a maioria dos metais preciosos presentes nas $\mathrm{PCl} .^{30} \mathrm{~A}$ ONU pede urgentemente providências para desenvolver novos processos para esse fim. ${ }^{30,72}$

Processos físicos, químicos e combinações deles servem para separar os metais uns dos outros. Devem ser levados em conta itens como energia, abundância do metal na $\mathrm{PCl}$, quantidade de placas, custo de reagentes, valor dos produtos recuperados e dos metais presentes nas placas. ${ }^{153} \mathrm{Em}$ um estudo verificou-se que há mais cobre nos celulares $(34,5 \% \times 23 \%$ em massa) que em $\mathrm{PCl}$ de computadores. ${ }^{120}$ Isso dirige o foco prioritário dos processos de reciclagem para metais: preciosos ( $\mathrm{PCl}$ de computadores) e cobre ( $\mathrm{PCl}$ de celulares). ${ }^{120}$

A recuperação dos metais nobres é essencial para assegurar sustentabilidade econômica do processo, mas deve ser incrementada pela agregação de outras frações, como a não-metálica. ${ }^{128} \mathrm{~A}$ recuperação de metais comuns tem um impacto substancial na economia do processo devido à maior quantidade disponível nas PCl. ${ }^{151}$

As etapas de pré-concentração (separação magnética, por eletroímã, óptica etc.) são importantes para o fracionamento da parte metálica. ${ }^{154}$ Grosso modo, distinguem-se duas frações: os metais ferrosos (ferro, cobalto, níquel e suas ligas), que são separados magneticamente dos demais metais, e os metais não ferrosos, em que se incluem os metais nobres e o cobre. $O$ emprego de etapas físicas de fracionamento tem a grande vantagem de reduzir o emprego de reagentes químicos (etapas químicas) para o isolamento dos diversos metais (e/ou seus compostos), minimizando a geração de resíduos, o gasto de insumos (água, energia) e os impactos ambientais intrínsecos a essas etapas. O complexo conjunto de etapas físicas e químicas tem respaldo no desafio de recuperar metais preciosos das $\mathrm{PCl}$ devido aos seus baixos teores nas placas (ressalvado o cobre) e aos interferentes (metais, não metais, compostos orgânicos) nas etapas de separação. ${ }^{30}$

Vale a pena recuperar elementos dos resíduos eletroeletrônicos por meio de processos metalúrgicos, pois há economia real de insumos e recursos naturais ao se processar fontes secundárias, embora isso varie de metal para metal. ${ }^{44}$ Hoje, processos hidrometalúrgicos (mediante o emprego de soluções aquosas) são amplamente empregados para processar a fração metálica das $\mathrm{PCl}^{70,128,155}$ Eles têm menor capital inicial, menor impacto ambiental, maiores recuperações em massa e adaptação para escalas menores em relação aos processos pirometalúrgicos (que não empregam solventes e são conduzidos em altas temperaturas), tipicamente encontrados em processos metalúrgicos. ${ }^{128} \mathrm{~A}$ lixiviação deve ser de natureza oxidativa porque os metais estão na forma reduzida, sozinhos ou na forma de ligas. ${ }^{30,128}$ A lixiviação ácida $(\mathrm{HCl}$, $\mathrm{H}_{2} \mathrm{SO}_{4}, \mathrm{HNO}_{3}$ ) na presença de um oxidante (como como $\mathrm{Cl}_{2}, \mathrm{H}_{2} \mathrm{O}_{2}, \mathrm{O}_{2}$ e $\mathrm{Fe}^{3+}$ ) $6,156,157$ é frequentemente explorada como primeiro estágio de lixiviação para solubilizar metais comuns, particularmente o cobre, na forma de cátions simples ou de ânions de ácidos complexos. A lixiviação do metal depende da sua afinidade com o lixiviante ácido. ${ }^{158} \mathrm{~A}$ lixiviação prévia de metais comuns garante o enriquecimento de metais preciosos não- 
reativos e insolúveis nos resíduos, facilitando a sua posterior recuperação. ${ }^{123}$ Menos comum é o emprego de soluções alcalinas (em presença de hidróxido de sódio ou de potássio - $\mathrm{NaOH} / \mathrm{KOH}$ ) de cianetos alcalinos ( $\mathrm{NaCN}$ e $\mathrm{KCN}$ ), rota muito utilizada na extração de ouro de minérios contendo baixos teores desse metal nobre. As lixiviações ácidas têm sérias restrições ambientais (geram enormes quantidades de resíduos aquosos corrosivos e sólidos pouco solúveis) ${ }^{70,81,127,131}$ e também apresentam risco de acidentes, ${ }^{159}$ mas dominam o processamento de frações metálicas pois podem ser controlados e monitorados com facilidade; ;28 exigem aparelhagem relativamente simples, muito embora normalmente tenham pouca seletividade. ${ }^{159}$ Assim, o desafio é desenvolver rotas ambientalmente mais compatíveis e de custo competitivo, ou melhorar as já existentes. ${ }^{128}$

$\mathrm{O}^{-1 N O}{ }_{3}$ (ácido nítrico) dissolve o cobre (> 6 $\left.\mathrm{mol} \mathrm{L}^{-1}\right)$ e a prata $\left(>8 \mathrm{~mol} \mathrm{~L}^{-1}\right)$ a quente. A prata pode ser recuperada por precipitação como cloreto $(\mathrm{AgCl})$, seguido de conversão a óxido $\left(\mathrm{Ag}_{2} \mathrm{O}\right) \mathrm{com} \mathrm{KOH}$ (hidróxido de potássio) e por fim à prata metálica adicionando peróxido de hidrogênio $\left(\mathrm{H}_{2} \mathrm{O}_{2}\right)$. O cobre é obtido por eletrodeposição. ${ }^{133} \mathrm{~A}$ concentração do ácido é o parâmetro operacional mais importante. 0 excesso de $\mathrm{HNO}_{3}$ pode ser recuperado por extração líquido-líquido (ELL) com TBP (fosfato de tributila) $50 \% \quad(\mathrm{v} / \mathrm{v})$ em querosene. ${ }^{133} \mathrm{Em}$ outra proposta, a fração metálica de $\mathrm{PCl}$ foi tratada com $\mathrm{H}_{2} \mathrm{SO}_{4}$ (ácido sulfúrico) $+\mathrm{HNO}_{3}$ concentrados a quente (mistura sulfonítrica). O cobre foi obtido por cementação com alumínio metálico, podendo ser oxidado a $\mathrm{CuSO}_{4}$ (sulfato de cobre) pela mesma mistura ácida oxidante acima e por fim cristalizado. $O$ alumínio também é recuperado por cristalização como sulfato. ${ }^{142} \mathrm{~A}$ fim de evitar a possível interferência do cobre, é necessário dissolvê-lo antes da lixiviação do ouro. ${ }^{121}$ Alguns processos de lixiviação foram desenvolvidos para recuperar o cobre das $\mathrm{PCl}$ devido à sua alta seletividade; tais processos incluem misturas de ácido nítrico, sulfato de amônio e cloreto de amônio. ${ }^{157}$
A solda é um desafio no processamento das $\mathrm{PCl}$ por conta da presença do chumbo. ${ }^{160}$ $\mathrm{HCl}$ (ácido clorídrico) $\sim 5 \mathrm{~mol} \mathrm{~L}^{-1}$ a quente (90 oC) dissolve o chumbo e o estanho com rendimentos elevados ( $>97 \%)$. O chumbo pode ser dissolvido por $\mathrm{HNO}_{3}$ 0,1 mol L-1 $(90$ oC). ${ }^{160} \mathrm{~A}$ placa pode ser empregada como carga aglomerante.

Não é raro encontrar propostas de dividir o processo de ataque ácido à fração metálica de $\mathrm{PCl}$ em duas etapas: lixiviação dos metais comuns e depois dos metais nobres por meio de reagentes como cianeto, tiossulfato, tioureia e haletos (haleto + halogênio). ${ }^{127,146,161}$ Como alternativas ao cianeto vem sendo testados, em meio ácido, 120,124,128,159,162 tioureia (oxidável e pouco estável em solução, e mais cara) e tiossulfato (consumo elevado, encarecendo o processo, reação lenta, exige cobre como agente oxidante; baixa economicidade). ${ }^{146,159}$ Contudo, esses compostos e seus derivados (que têm em comum o elemento enxofre) são bem mais seletivos que os reagentes tradicionais (há poucos interferentes químicos), inclusive em nível de gestão de resíduos. ${ }^{128,159,163}$ Íons $\mathrm{Fe}(\mathrm{III})$ catalisam $\mathrm{O}$ processo. ${ }^{164} \mathrm{O}$ metal nobre fica em um complexo catiônico, ao contrário dos processos normais. ${ }^{159} \mathrm{~A}$ moagem das $\mathrm{PCl}$ até 100 mesh facilita muito a dissolução do ouro e da prata de placas de telefonia celular, quando tratadas por solução aquosa ácida de tioureia. ${ }^{159}$

Novos processos ambientalmente mais amigáveis e com perspectivas de escala econômica foram recentemente propostos para processamento da fração metálica de $\mathrm{PCl}^{43}$ tais como moagem criogênica, ${ }^{43}$ separação eletrostática por efeito corona, ${ }^{152}$ processamento a vácuo, ${ }^{44}$ extração sob condições ambientes e tecnologias eletroquímicas. ${ }^{46}$ Embora apresentem vantagens em relação aos métodos tradicionais, a maioria delas ainda se restringe à escala de bancada e também possuem problemas referentes a resíduos finais de processo. ${ }^{44,46}$ Líquidos iônicos substituem os meios ácidos tradicionais de dissolução de metais, e são considerados ambientalmente 
verdes. ${ }^{127} \mathrm{~A}$ biolixiviação de metais nobres e não nobres é uma possibilidade, mas faltam estudos sistemáticos e questões operacionais a resolver. ${ }^{163}$ Ainda precisam ser superadas dificuldades como longos tempos de residência, baixas densidades de polpa, toxicidade de metais sobre os microorganismos e baixos níveis de extração. ${ }^{128,165}$ Há a possibilidade de descobrir novos microorganismos ou modificar os existentes, particularmente com capacidade de trabalhar a temperaturas mais elevadas. ${ }^{165}$

Um processo alternativo aos pirometalúrgicos convencionais emprega a mistura eutética $\mathrm{NaOH}+\mathrm{KOH}$ ( $300 \cong \mathrm{C}, 1$ h sob fluxo de argônio), que dissolve materiais vítreos, degrada polímeros e reage com óxidos ácidos e anfóteros. Metais nobres praticamente não reagem, não fundem e não formam ligas devido à baixa temperatura de processo. Obtém-se uma fração rica em cobre contendo outros metais nobres, livres de polímeros e materiais vítreos. Halogênios como cloro e bromo são aprisionados na mistura fundida como cloreto/brometo, bem como o carbono (na forma de carbonatos). Em ausência de oxigênio, produz-se gás hidrogênio. ${ }^{166}$

Outro processo não convencional emprega plasma acoplado seguido de lixiviação ácida do material termicamente tratado. ${ }^{129} \mathrm{O} \mathrm{HCl}$ dissolveu mais de $90 \%$ do $\mathrm{Cu}$, Ni e Co, e menos de $40 \%$ de $\mathrm{Fe}$ e Al. O plasma permite uma melhor separação da fração metálica. $O$ efluente gasoso não contém substâncias tóxicas acima dos limites permitidos pelas legislações. O cobre está predominantemente sozinho e os demais metais em ligas. O resíduo insolúvel tratado com $\mathrm{HCl} 12 \mathrm{~mol} \mathrm{~L}^{-1}+\mathrm{H}_{2} \mathrm{O}_{2}$ a 25 ㅇ C concentra os metais preciosos em uma nova fração insolúvel.

Em solução, os metais podem ser separados por meio de uma combinação de técnicas: precipitação, extração por solventes (SX), redução química, volatilização, cristalização fracionada, adsorção, troca iônica, cementação e eletrodeposição podem ser facilmente explorados. Fala-se em combinação porque muitos dos elementos em solução aquosa possuem um comportamento químico semelhante, o que dificulta a separação entre eles. A seleção e o desenvolvimento dos processos de fracionamento e recuperação de metais dependem de fatores como sistema de lixiviação, concentração de metais e impurezas/interferentes presentes. ${ }^{128,155}$ Todas essas técnicas possuem vantagens e desvantagens relacionadas ao consumo de reagentes e outros insumos, geração de resíduos, eficiência de processo (seletividade, rendimento), maior ou menor risco de danos à saúde e impactos ambientais. A maioria desses métodos foi testada em escala de laboratório. ${ }^{43}$ Uma sequência de etapas de separação deve prever que o produto de uma etapa seja a matéria-prima da seguinte. A chave para a escolha dos métodos a serem aplicados é a concentração dos metais presentes na solução. Por isso, cada caso é um caso porque a composição das $\mathrm{PCl}$ varia segundo o EEE considerado e ao longo das gerações de um mesmo EEE. ${ }^{120}$

O método de separação mais simples, barato e usado nas rotas hidrometalúrgicas é a precipitação química, especialmente de metais não nobres. ${ }^{158,167-169}$ No entanto, íons metálicos presentes em pequenas quantidades podem influenciar a pureza dos produtos finais. A extração por solventes tem recebido muita atenção devido às suas vantagens como alta seletividade e possibilidade de ampliação da escala. ${ }^{108,170,171}$ É uma ferramenta particularmente eficaz para separar metais nobres e cobre de

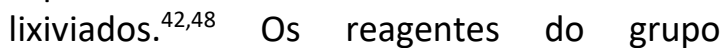
hidroxioxima têm seletividade excepcional para a extração de cobre(II) a partir de soluções ácidas de sulfato/cloreto (pH 1-2) na presença de ferro(III). ${ }^{172-176}$

Os metais nobres são frequentemente isolados por redução química mediante emprego de corrente elétrica (eletrodeposição) ou metais redutores (cementação) como zinco, magnésio etc. face aos seus elevados potenciais de redução.

A natureza multicomponente da fração metálica explica porque, mesmo com todas as 
estratégias de separações prévias por métodos físicos, não se evitam as etapas químicas para isolamento dos metais de interesse. São misturas de metais e ligas com propriedades físicas e químicas diferentes, e a dissolução, total ou parcial dos mesmos, é o caminho normalmente tomado para fracionálos depois. A energia usada para reduzir os metais quando da confecção das peças é perdida na dissolução química, o que é uma grande desvantagem em termos de consumo energético, mas esse fato pode ser ao menos contrabalançado em parte se a meta é obter um composto definido do metal. ${ }^{172,175}$

A recuperação de metais das placas segue a seguinte ordem geral de hierarquia: ouro, cobre, prata, paládio, alumínio, estanho, chumbo, platina, níquel e zinco, mas a variação de composição segundo a $\mathrm{PCl}$ e até gerações de um mesmo equipamento pode alterar essa prioridade. Isso é particularmente notado em gerações nos quais metais nobres foram no todo ou em parte substituídos por outros componentes mais baratos com desempenho similar, pois modifica a cadeia recicladora a ser estabelecida para processálos. $^{64}$

Apesar da pesquisa intensiva neste campo, muitos dos processos não atingiram a operação em escala comercial devido a vários inconvenientes, como elevado consumo de energia e a grande quantidade de resíduos produzidos, causando poluição secundária. ${ }^{81,127,177} \mathrm{O}$ fluxo de recuperação de metais em resíduos de $\mathrm{PCl}$ é longo e complicado devido à baixa seletividade de ácidos inorgânicos como agentes de lixiviação, ${ }^{123}$ levando a um alto custo de operação..$^{22,81,123}$ Sua gestão é essencial para minimizar impactos ambientais. ${ }^{177}$

\subsection{Tubos de raios catódicos}

Da mesma forma que as $\mathrm{PCl}$, os tubos de CRT são ao mesmo tempo fonte de metais preciosos e tóxicos. ${ }^{68} \mathrm{~A}$ quantidade de metais preciosos (paládio, prata, ouro) e tóxicos depende do tamanho da TV (ou monitor) e de sua tecnologia. Ítrio, európio e índio aparecem com destaque devido à deficiência de produção de fontes primárias. ${ }^{68,159}$ Estima-se que menos de $30 \%$ dos CRT são reciclados de alguma forma no mundo, 60 \% são dispostos em aterros e $10 \%$ são queimados. ${ }^{84}$

O CRT é composto principalmente por materiais vítreos que compõem $80-90 \%$ de sua massa. ${ }^{137} \mathrm{O}$ vidro de um CRT típico é composto de 65-72 \% da tela frontal e 28-35 $\%$ de vidro plumbífero (incluindo a sua parte afilada, o "funil"). ${ }^{64,137} \mathrm{~A}$ tela frontal contém tipicamente $12 \%$ de $\mathrm{BaO}$ (óxido de bário) e 12 \% de SrO (óxido de estrôncio), com 0-3 \% de $\mathrm{PbO}$ (óxido de chumbo). O vidro plumbífero contém de 25 a $30 \%$ em massa de $\mathrm{PbO}^{137}$ Os dois vidros devem ser separados porque suas composições são bem distintas. ${ }^{178} \mathrm{O}$ item 6.2.2. resume as técnicas disponíveis de separação desses vidros. A separação perfeita dos vidros frontal e plumbífero é decisiva na viabilidade econômica de reciclar os CRT. ${ }^{68,83}$ Feito isso, o restante do procedimento é bastante simples: separação dos dois vidros, remoção do suporte interno metálico e aspiração do "pó de fósforo" colocado na face interna do vidro frontal.

A segregação das partes de um CRT não envolve processos químicos e os componentes segregados são relativamente poucos. O "pó de fósforo" é altamente tóxico tanto do ponto de vista químico como pelo fato de ser extremamente fino. Análises químicas apontam para a presença de $\mathrm{YPO}_{4}$ (fosfato de ítrio contendo elementos da série lantanídea), sulfetos de zinco e cádmio (ZnS, CdS), vanádio, cobalto, ferro, bário, estrôncio e silício. ${ }^{179}$

Se a separação dos CRT em seus componentes não chega a ser uma tarefa difícil, a grande dificuldade é gerenciar alguns de seus componentes. ${ }^{68} \mathrm{O}$ uso de tecnologias sem chumbo dificulta a reciclagem dos CRT a menos que se remova a capa externa desse metal do vidro plumbífero. ${ }^{67} 0$ mercado consumidor reticente em aceitar produtos que têm ou tiveram chumbo é uma dificuldade a ser superada. ${ }^{180}$ 
Soluções para o vidro frontal e o "fósforo" ainda são muito escassas e faltam estudos de aproveitamento. ${ }^{137} \mathrm{O}$ vidro de CRT possui baixa absorção de água e é rico em sílica, o que o torna adequado para uso como areia ou pozolana em materiais de construção. A preparação de argamassa, pasta e concreto de cimento a partir do vidro CRT oferece implicações ambientais e econômicas atraentes. ${ }^{181} \mathrm{O}$ método de lixiviação ácida é uma tecnologia amplamente utilizada na extração de elementos da série lantanídia presentes no "pó de fósforo"; o ácido sulfúrico (na presença de peróxido de hidrogênio) é muito eficiente para esse fim, mais do que com ácido clorídrico. ${ }^{182} \mathrm{~A}$ partir do lixiviado, a extração por solventes, a precipitação de oxalatos e a extração em fase sólida constituíram processos viáveis de isolamento dos elementos da série lantanídia.

Se o mercado de CRTs está em extinção (pois de um CRT se pode fabricar outro, como no caso dos vidros comuns - ciclo fechado ${ }^{64,178}$ ), o emprego do vidro plumbífero é muito restrito devido ao alto teor de chumbo. ${ }^{134}$ Aponta-se a possibilidade de empregar o vidro plumbífero como agregado fino pesado em concreto pesado, devido à sua massa específica relativamente elevada ( $3 \mathrm{~g}$ $\mathrm{cm}^{-3}$ - o chumbo é um metal bastante denso, bem como seus compostos). ${ }^{134,178,183}$ Concreto com mais de $2,6 \mathrm{~g} \mathrm{~cm}^{-3}$ é considerado como pesado, sendo usado em instalações nucleares. Para usar o vidro com chumbo, deve-se limitar a $25 \%$ da massa de substituto no cimento. ${ }^{134}$

O chumbo pode ser removido quimicamente de uma camada superficial plumbífera por meio de lixívias alcalinas ou ácidas no vidro moído $(<5 \mathrm{~mm}) .{ }^{134} \mathrm{O}$ ácido nítrico remove-o facilmente. ${ }^{178}$ Os melhores métodos de remover $\mathrm{PbO}$ dos vidros são hidrometalúrgicos, especialmente ácidos. ${ }^{137} \mathrm{~A}$ solução obtida pode ser usada para isolar o chumbo como um sal (nitrato, cloreto etc.) ou obtê-lo na forma metálica, com emprego na indústria de baterias automotivas.

Um processo inovador e eficaz para tratamento do vidro plumbífero consiste na remoção do chumbo por fusão a alta temperatura ( $1.200 \stackrel{\circ}{\circ})$. O carbonato de sódio foi usado como fundente, sulfeto de sódio como agente catalítico, e carbono em pó como agente redutor. A taxa de recuperação de chumbo (como metal) nas condições ótimas foi de $94 \%$ em massa. O silicato de chumbo foi primeiramente formado e depois decomposto. A escória de vidro pode ser transformada em silicato de sódio e potássio pelo processo de hidrólise. ${ }^{184}$

O vidro sem chumbo pode ser usado como fluxo em metalurgia (escorificador). ${ }^{67,178}$ Outra possibilidade é fabricar vidros para lâmpadas fluorescentes. ${ }^{149}$ Produtos cerâmicos e vítreocerâmicos, da área nuclear, ${ }^{137,178}$ compósitos vítreos e vidros resistentes a raios $x$ são outras vias a serem testadas, ${ }^{137}$ mas os custos de preparação do material vítreo de um tubo de CRT ainda são um desafio. ${ }^{178}$ Os vidros são quebrados e depois pulverizados em moinhos. ${ }^{178}$

\subsection{Telas de LCD}

Uma tela de cristal líquido (TCL ou LCD liquid crystal display) contém basicamente uma mistura de 10 a 20 substâncias responsáveis pelas cores e a definição da tela. Essas substâncias incluem fenilciclo-hexanos, alquilbenzenos e ciclo-hexilbenzenos. Os cristais líquidos são inseridos entre camadas muito finas de vidro e elementos de controle de fluxo elétrico. ${ }^{185}$ Uma tela de telefone celular pode conter cerca de $0.5 \mathrm{mg}$ de cristais líquidos enquanto um laptop possui cerca de $500 \mathrm{mg}$. No total já foram identificados mais de 250 substâncias em formulações de LCDs, incluindo halogênios (bromo e iodo), tungstênio, alumínio, ferro, cobre e níquel. ${ }^{185}$ $\mathrm{O}$ advento de TVs e monitores de alta definição exige LCDs contendo o chamado thin film transistor $L C D$ (tela de cristal líquido com transistor de filme fino), que é principalmente fabricado com misturas de óxidos de estanho $\left(\mathrm{SnO}_{2}, 10 \% \mathrm{~m} / \mathrm{m}\right)$ e de índio $\left(\mathrm{In}_{2} \mathrm{O}_{3}, 90 \%\right.$ $\mathrm{m} / \mathrm{m}$ ), que é conhecido como ITO (Indium tin oxide). ${ }^{186}$ Os filmes finos de ITO têm 
importantes propriedades: são transparentes, eletricamente condutores e refletem a radiação infravermelha. As aplicações do ITO são variadas. Os filmes de ITO respondem por mais da metade do emprego do índio na atualidade, e são a parte mais valiosa das telas de $L C D$, razão pela qual muitos dos estudos de processamento focam a recuperação desse elemento. ${ }^{187-191} \mathrm{O}$ ITO presente nos resíduos de LCD é considerada a matéria-prima secundária mais importante para a produção de índio. ${ }^{191,192} \mathrm{O}$ índio é um metal raro e estratégico e é obtido principalmente como subproduto da produção de zinco e chumbo. $\mathrm{O}$ teor médio de índio nos minérios de zinco varia de menos de 1 a 100 ppm ( $\mathrm{mg} \mathrm{kg}^{-1}$ ), enquanto nas telas de LCD está presente em aproximadamente 250 ppm. ${ }^{189} \mathrm{Em} \mathrm{2015}$, a produção mundial foi estimada em 755 t, sendo a China o principal produtor. Depois de 2007, a quantidade de índio produzida a partir de matérias-primas secundárias foi superior à das matérias-primas primárias. ${ }^{186,191}$

As primeiras pesquisas acerca do que fazer com LCDs de resíduos de equipamentos eletroeletrônicos apareceram há pouco mais de 10 anos. ${ }^{192}$ Uma das ideias é a incorporação de LCD em materiais vítreos ou vítreocerâmicos, ${ }^{188}$ mas isso impede que elementos de valor agregado elevado possam ser recuperados. ${ }^{193}$

Após a separação das lâminas de uma tela de LCD (Figura 8), a lâmina contendo ITO pode ser triturada ou não antes do processamento químico. ${ }^{190,194-196}$ Um método de lixiviação sem trituramento se baseia na lixiviação com $\mathrm{HCl}$ sob aplicação de ondas ultrassônicas Os resultados demonstraram que o índio pode ser lixiviado eficientemente mesmo sob baixa concentração de ácido clorídrico $\left(0,8 \mathrm{~mol} \mathrm{~L}^{-1}\right)$ (>95 \% em $1 \mathrm{~h}$ ) sob ondas ultrassônicas de 300 W. ${ }^{190} \mathrm{Em}$ outra proposta, a lâmina foi pulverizada através de um tratamento mecânico, e o material obtido foi lixiviado com uma mistura $\mathrm{HCl}: \mathrm{HNO}_{3}$ sob ondas ultrassônicas, ${ }^{195}$ com as misturas $\mathrm{H}_{2} \mathrm{SO}_{4}+$ $\mathrm{H}_{2} \mathrm{O}_{2},{ }^{191,196} \mathrm{HNO}_{3}+\mathrm{HCl}^{187}$ ou $\mathrm{H}_{2} \mathrm{SO}_{4}+\mathrm{HCl}^{197}$

A aplicação de ultrassom apresenta diversas vantagens em relação ao processo de lixiviação tradicional, como cinética rápida e controlável, alto rendimento de extração de índio e estanho, possibilidade de recuperação seletiva desses dois metais e possibilidade de reciclar o vidro puro separadamente, evitando processos de separação adicionais. ${ }^{191}$

Os teores de índio nos lixiviados ácidos geralmente são muito pequenos. Portanto, essa solução deve ser concentrada antes de ser submetida à etapa de isolamento do elemento. A extração líquido-líquido desempenha papel importante na recuperação do índio a partir de uma solução muito diluída obtida a partir da lixiviação ácida de telas de LCD. ${ }^{190}$ Alguns dos extratantes utilizados são D2EHPA (ácido di-2etilhexilfosfórico) e TBP (fosfato de tributila). Os resultados indicaram que a extração por solvente é um método efetivo para a separação do índio, sozinho ou conjuntamente com o estanho. ${ }^{188}$ É possível o emprego de ligantes quelantes aminopolicarboxilados (APCS), incluindo o EDTA (ácido etilenodiaminotetra-acético). Os APCs são capazes de formar complexos estáveis com o índio presente nos filmes de ITO à temperatura ambiente em $\mathrm{pH}=5 .{ }^{198}$ Essa técnica pode ainda ser extendida para a recuperação de outros elementos raros e valiosos, como Ge, Ta e Ti. ${ }^{194}$ A troca iônica é outro método conveniente para isolar o índio, por meio de resinas meso e macroporosas do tipo poli(estireno-divinilvenzeno). ${ }^{195,196} \mathrm{~A}$ dessorção com ácido forte $\left(\mathrm{H}_{2} \mathrm{SO}_{4}, \mathrm{HCl}\right)$ permite obter uma solução do elemento muito mais concentrada.

Menos convencional é o processo de pirólise das telas de LCD, pois liberam-se gases muito tóxicos. $\mathrm{O}$ resíduo pode ser dissolvido em $\mathrm{H}_{2} \mathrm{SO}_{4} 0,6 \mathrm{~mol} \mathrm{~L}^{-1}$ por $42 \mathrm{~min}$ a $65 \stackrel{\circ}{\circ}$, condição em que quase $100 \%$ do índio foi dissolvido. ${ }^{25}$

Como em qualquer outro tipo de tecnologia, a tela de LCD possui suas inovações. Atualmente, existem diversas variações de telas em utilização, como por exemplo, os nemáticos supertorcidos (STN), nemáticos torcidos de camada dupla (DSTN), cristal líquido ferroelétrico (FLC) e cristal líquido ferroelétrico estabilizado por superfície (SSFLC). ${ }^{98}$ Isso implicará em 
adaptações das metodologias em estudo para processar as telas de LCD.

\section{P \& D no Brasil para Processamento de Equipamentos Eletroeletrônicos}

No Brasil, P \& D em EEE é muito incipiente. Em 2012, dos 141 grupos de pesquisa que lidavam com resíduos de algum tipo identificados, a maioria não contemplava diretamente os EEE. Em 2018, a mesma busca revelou a existência de mais de 1.700 grupos relacionados a resíduos, mas apenas 15 têm o tema EEE como parte de suas pesquisas. O estado de Minas Gerais possui um levantamento bem detalhado, graças a uma parceria com o secretariado do estado suíço para negócios econômicos e instituto suíço de ciências materiais e tecnologia. ${ }^{97,107} \mathrm{~A}$ resposta dos setores produtivo e acadêmico ainda é muito fraca à PNRS. ${ }^{39,199} \mathrm{O}$ poder público não dispõe de controle sobre o número de empresas de reciclagem de REEE ativas no país, e quais empresas mantêm parcerias com universidades e centros de pesquisa. ${ }^{31,107}$

Os processos de reciclagem e reutilização de REEE no Brasil são descentralizados e, portanto, o desenvolvimento de uma rede de cooperação como um todo é complexo. ${ }^{199}$ Quase $90 \%$ das empresas realizam apenas a fase de pré-tratamento (desmantelamento e segregação de componentes), e pelo menos $92 \%$ delas desmantelam manualmente os REEE. ${ }^{107}$ Além disso, o mercado brasileiro opera na concentração dos materiais mais valiosos presentes nos REEE, enviando-os para o exterior. A recuperação de metais preciosos das $\mathrm{PCl}$ é um processo realizado por empresas estrangeiras, ${ }^{107}$ pois os fabricantes e recicladores brasileiros não possuem tecnologia suficiente devido à falta de recursos para investimento. Assim, o governo brasileiro vem realizando reuniões com os fabricantes e recicladores para desenvolver um acordo setorial com o objetivo de apoiar financeiramente a transferência dessa tecnologia para reciclagem das $\mathrm{PCl}$ no Brasil. ${ }^{199-201} \mathrm{O}$ governo deve coparticipar dos programas de gestão a serem implantados. ${ }^{88} \hat{E}$ preciso mais estímulo para que a tríade academia-indústria-governo faça projetos cooperativos para estimular a gestão e a reciclagem do EEE no Brasil. ${ }^{97,199}$

\section{Concepção de Futuras Gerações de Equipamentos Eletroeletrônicos}

Uma idéia é repensar o design dos produtos para facilitar o reúso e a sua remanufatura (acesso a partes internas, troca de placas, repintura, reduzir complexidade dos componentes, compatibilidade entre modelos de diferentes fabricantes, intercâmbio de peças...), ou seja, conceber produtos que sejam mais facilmente desmontados ao final da vida útil, ${ }^{136}$ dentro dos princípios da ecoeficiência e ecodesign. ${ }^{34,49,88,112,193,202,203} \quad$ Ecobalanço, conhecido também como análise de ciclo de vida (ACV), ou ainda análise do berço ao túmulo, é a investigação e avaliação dos impactos ambientais causados por/necessários à existência de um determinado produto ou serviço. ${ }^{204}$ Esse pensamento é fortemente centrado no fornecimento crítico de alguns metais que aparecem em EEE. ${ }^{34,205,206}$ A metodologia envolve obrigatoriamente compromisso com a segurança, aspectos econômicos e a avaliação dos impactos ambientais (emissões de $\mathrm{CO}_{2}$ etc.). ${ }^{203}$

Segundo o protocolo estabelecido na portaria europeia 2002/96/EC, deve-ser fazer a remoção de partes perigosas em EEE em plantas específicas para esse fim. ${ }^{193}$ As melhores remoções são das baterias (72 \%), enquanto que o total só chega a $21 \%$ no caso das telas de cristal líquido. Outros itens incluídos nesse protocolo são: capacitores, $\mathrm{PCl}$, cartuchos de impressora, componentes contendo amianto, mercúrio e fibras 
cerâmicas, radioativos, retardantes de chama bromados e cabos elétricos externos. . $^{49,193,205}$

A versão atual do RoHS (Restriction of Certain Hazardous Substances, Restrição de Certas Substâncias Perigosas) é de 2011 (2011/65/EU), e começou a vigorar em setembro de 2012. Ele prevê a restrição ao uso de substancias tóxicas em EEE e facilitar a coleta e reciclagem/disposição dos mesmos usados. $^{17,83}$ São 11 categorias, abrangendo desde dispositivos de iluminação até equipamentos médicos. Mercúrio, chumbo, cádmio, cromo hexavalente, bifenilas polibromadas e difenil éteres polibromados são restritos em $\operatorname{EEE~}(\leq 0,1 \%$ em massa, exceto cádmio, $\leq 0,01 \%$ ) das versões mais recentes.

Para futuras gerações verdes de EEE, devese banir ou restringir o uso de substâncias tóxicas, inclusive substituindo-as por produtos de fontes renováveis, como os plásticos biodegradáveis, ou ainda aqueles à base de ácido polilático. ${ }^{77}$

Uma das alternativas para o futuro é a substituição de retardantes de chama bromados por outros não bromados. Nas novas gerações de EEE, na China, já não aparece bromo nos retardantes usados em celulares, mas ainda aparece em computadores e TVs. ${ }^{166} \mathrm{Um}$ exemplo são os retardantes à base de compósito de ácido polilático-óxido de alumínio, ${ }^{93}$ cuja interferência no processo de reciclagem das frações plástica e metálica das $\mathrm{PCl}$ parece ser bem menor.

A cadeia da fase de final de vida dos equipamentos eletroeletrônicos é bastante complexa e depende do tipo de equipamento, assim como, principalmente da legislação, condições locais e disponibilidade de informações e rastreamento do fluxo de produtos usados. A legislação europeia de resíduos sólidos e, particularmente a voltada para REEE, exerceu papel relevante na minimização dos impactos no final de suas vidas, tendo influenciado a redução de substâncias perigosas no design dos produtos. Incentivados pela legislação europeia, muitos estudos de ACV foram desenvolvidos focados na análise de fim de vida dos produtos. Nessas análises da fase de fim de vida de produtos, frequentemente prioriza-se a avaliação da recuperação de energia e de materiais através da reciclagem, compostagem ou incineração dos resíduos. ${ }^{204}$

Nas atuais legislações tanto na UE, como no Brasil, há pouco foco no reúso. ${ }^{25,109,206}$ Há uma relevante redução de impactos com a remanufatura de desktops, mesmo que representem apenas o adiamento de uma situação em que virarão resíduo eletroeletrônico.

\section{Conclusões}

$O$ século $X X$ deve ser visto como o do desenvolvimento socioeconômico baseado no consumo intensivo de recursos limitados e não renováveis, exemplificado pelos produtos eletroeletrônicos, um dos símbolos da sociedade de consumo e do descartável. Recursos preciosos foram convertidos em problemas ambientais e de saúde humana através da criação de grandes volumes de resíduos cuja reciclagem é difícil porque não foram concebidos para tal, caracterizando um comportamento de uma sociedade insustentável. Os resíduos eletroeletrônicos são um dos símbolos do Antropoceno: estão inseridos no contexto da "Grande Aceleração", integram a tecnosfera, podem produzir tecnofósseis e produzem impactos ambientais e danos à saúde.

$O$ século XXI tem de ser o da mudança de atitude (socioeconômica e técnico-científica). As tecnologias devem ser sustentáveis e é preciso a integração governo - indústria academia. A indústria participa da coleta e da logística reversa dos produtos usados; o governo propicia leis e incentivos para a reciclagem; a academia desenvolve analises de ciclos de vida e processos de reciclagem dos EEE, sendo importante que cada país desenvolva sua própria solução, e que não exporte seus resíduos eletroeletrônicos para outras regiões, especialmente aquelas cuja legislação é precária, pois as diferenças 
culturais, tecnológicas e econômicas não justificam esse procedimento.

Ao lado de componentes diretamente recicláveis após a manufatura reversa de um produto eletroeletrônico, existem outros para os quais, apesar de todo o esforço em pesquisa e desenvolvimento nos últimos anos, ainda não se chegou a soluções satisfatórias sob os pontos de vista econômico e ambiental. É de se destacar que todo esse esforço contempla apenas 1-2 \% da massa dos insumos que foram convertidos em um produto eletroeletrônico que chegou ao fim de sua via útil. Por isso, uma medida eficaz para enfrentar o problema do resíduo eletroeletrônico é focar a sua origem por meio de práticas de consumo consciente. Não se trata de negar o acesso de produtos eletroeletrônicos às pessoas, mas sim perguntar-lhes, por exemplo: será preciso trocar de telefone celular todo ano apenas para dispor da última palavra em tecnologia?

A gestão dos resíduos eletroeletrônicos no Brasil está ainda na sua infância, não há infraestrutura montada que atenda às diferenças regionais e à extensão territorial. Mesmo as iniciativas já existentes não têm suficiência para processar $100 \%$ dos EEE. Pelo viés tecnológico, deve ser incentivado o desenvolvimento de tecnologias de reciclagem que abranjam todos os componentes dos $\mathrm{EEE}$, inclusive aqueles mais complexos como as $\mathrm{PCl}$, os tubos de CRT e as telas de LCD. A reciclagem no país é muito incipiente e não organizada em escala, resultando em exportação de itens que possuem bom valor agregado. O maior desafio nacional é o estabelecimento de um sistema de coleta seletiva eficiente e de uma logística reversa robusta e de alta capilaridade, dirigindo a cadeia da coleta e da reciclagem informal para o mercado formal, minimização os impactos ambientais e sociais.

Mitigar o desafio dos resíduos eletroeletrônicos passa pela capacidade de a humanidade ter o discernimento de sua responsabilidade em usufruir de um espetacular produto tecnológico sem alimentar a cadeia insustentável do seu modo de produção. A Terra, o único lar que a humanidade dispõe, e seus recursos são limitados. As preocupações com os impactos das ações humanas sobre o planeta extrapolaram o âmbito científico. Líderes de diversas denominações religiosas chamam a atenção para a fase que a humanidade atravessa e a necessidade do envolvimento coletivo para fazer frente a ela.

Consciência ambiental é a chave para que todos possam mudar de atitude e ter um novo olhar que relaciona a tecnologia dos produtos eletroeletrônicos e o futuro. Do contrário, além das evidências físicas tangíveis do Antropoceno, haverá, talvez, outras marcas desta nova época: as gerações futuras haverão de lamentar profundamente o desperdício de recursos naturais não renováveis motivados por uma espiral de consumo insensata, e que obrigará, com o esgotamento das fontes primárias, a que das montanhas de resíduos e dos tecnofósseis se extraiam os elementos e outros materiais para evitar o colapso da civilização como a conhecemos hoje.

\section{Referências Bibliográficas}

${ }^{1}$ Donges, J. F.; Lucht, W.; Hansen, F. M.; Steffen, $W$. The technosphere in Earth system analysis: a coevolutionary perspective. The Anthropocene Review 2017, 4, 23. [CrossRef]

${ }^{2}$ Haff, P. Humans and technology in the Anthropocene: Six rules. The Anthropocene Review 2014, 1, 126. [CrossRef]

${ }^{3}$ Rosol, C.; Nelson, S.; Renn, J. In the machine room of the Anthropocene. The Anthropocene Review 2017, 4, 2. [CrossRef]

${ }^{4}$ Rahmani M.; Yaghamaeian K.; Nabizadeh R.; Yunesian $M$. Estimation of waste from computers and mobile phones in Iran. Resources, Conservation and Recycling 2014, 87, 21. [CrossRef]

${ }^{5}$ Estrada-Ruiz R. H.; Flores-Campos R.; GámezAltamirano H. A.; Velarde-Sánchez E. J. Separation of the metallic and non-metallic 
fraction from printed circuit boards employing green technology. Journal of Hazardous Materials 2016, 311, 91. [CrossRef]

${ }^{6}$ Ackil, A.; Erust, C., Gahan, C. S.; Ozgun, M.; Sahin, M.; Tuncuk.; A. Precious metal recovery from waste printed circuit boards using cyanide and non-cyanide lixiviants - A review. Waste Management 2015, 45, 258. [CrossRef]

${ }^{7}$ Huang, J.; Chen, M.; Chen, H.; Chen, S.; Sun, Q. Leaching behavior of copper from waste printed circuit boards with Brønsted acidic ionic liquid. Waste Management 2014, 34, 483. [CrossRef]

${ }^{8}$ Hadi, P.: Xua, M.; Lin, C. S. K.; Hui, C. W.; McKay, G. Waste printed circuit board recycling techniques and product utilization. Journal of Hazardous Materials 2015, 283, 234. [CrossRef]

${ }^{9} 9$ Sarvar, M.; Salarirad, M. M.; Shabani, M. A. Characterization and mechanical separation of metals from computer Printed Circuit Boards (PCBs) based on mineral processing methods. Waste Management 2015, 45, 246. [CrossRef]

${ }^{10}$ Wang, F.; Zhao,Y.; Zhang, T.; Duan, C.; Wang, L. Mineralogical analysis of dust collected from typical recycling line of waste printed circuit boards. Waste Management 2015, 43, 434. [CrossRef]

${ }^{11}$ Cucchiella, C.; D'Adamo, I.; Koh, S. C. L.; Rosa, P. Recycling of WEEEs: An economic assessment of present and future e-waste streams. Renewable \& Sustainable Energy Reviews 2015, 51, 263. [CrossRef]

12 Vats, M. C.; Singh. S. K. Assessment of gold and silver in assorted mobile phone printed circuit boards (PCBs). Waste Management 2015, 45, 280. [CrossRef]

${ }^{13}$ Rubin, R. S.; Castro, M. A. S.; Brandão, D.; Schalch, V.; Ometto, A. R. Utilization of Life Cycle Assessment methodology to compare two strategies for recovery of copper from printed circuit board scrap. Journal of Cleaner Production 2014, 64, 297. [CrossRef]

${ }^{14}$ Perkins, D. N.; Drisse, M. N. B.; Nxele, T.; Sly, P. D. E-waste: A global hazard. Annals of Global Health 2014, 80, 286. [CrossRef]
${ }^{15}$ Gao, X.; Li, Q.; Qiu J. Hydrothermal modification and recycling of nonmetallic particles from waste print circuit boards. Waste Management 2018, 74, 427. [CrossRef] ${ }^{16}$ Rahman, S.; Subramanian, N. Factors for implementing end-of-life computer recycling operations in reverse supply chains. International Journal of Production Economics 2012, 140, 239. [CrossRef]

${ }^{17}$ Tanskanen, P. Management and recycling of electronic waste. Acta Materialia 2013, 61, 1001. [CrossRef]

${ }^{18}$ Foelster, A. S.; Andrew, S.; Kroeger, L.; Bohr, P.; Dettmer T.; Boehme, S.; Herrmann, C. Electronics recycling as an energy efficiency measure e a Life Cycle Assessment (LCA) study on refrigerator recycling in Brazil. Journal of Cleaner Production 2016, 129, 30. [CrossRef]

${ }^{19}$ Waters, C. N.; Zalasiewicz, J.; Summerhayes, C.; Barnosky, A. D.; Poirier, C.; Gauszka, A.; Cearreta, A.; Edgeworth, M.; Ellis, E. C.; Ellis, M.; Jeandel, C.; Leinfelder, R.; McNeill, J. R.; Richter, D. B.; Steffen, W.; Syvitski, J.; Vidas, D.; Wagreich, M.; Williams, M.; Zhisheng, A.; Grinevald, J.; Odada, E.; Oreskes, N.; Wolfe, A. $P$. The Anthropocene is functionally and stratigraphically distinct from the Holocene. Science 2016, 351, 137. [CrossRef]

${ }^{20}$ Edgeworth, M.; Richter, D. D.; Waters, C.; Haff, P.; Neal, C.; Price, S. J. Diachronous beginnings of the Anthropocene: the lower bounding surface of anthropogenic deposits. The Anthropocene Review 2015, 2, 33. [CrossRef]

${ }^{21}$ Francisco, Papa. Carta Encíclica Laudato Si', 1a ed., Paulinas: São Paulo, 2015, cap. I, III e VI.

${ }^{22}$ Computer and the Environment: Understanding and Managing Their Impacts; The United Nations University, Kluwer: Amsterdam, 2004.

${ }^{23}$ Vasile, C.; Brebu, M. A.; Totolin, M.; Yanik, J.; Karayildirim, T.; Darie, H. Feedstock recycling from the printed circuit boards of used computers. Energy Fuels 2008, 22, 1658. [CrossRef] 
${ }^{24}$ Torres, R.; Lapudus, G. T. Closed circuit recovery of copper, lead and iron from electronic waste with citrate solutions. Waste Management 2017, 60, 561. [CrossRef]

${ }^{25}$ Araújo, M. G.; Tese de Doutorado, Universidade Federal do Rio de Janeiro, 2013.

${ }^{26}$ Zalasiewicz, J.; Williams, M.; Waters, C. N.; Barnosky, A. D.; Palmesino, J.; Rönnskoog, A. S.; Edgeworth, M.; Neal, C.; Cearreta, A.; Ellis, E. C.; Grinevald, J.; Haff, P.; Sul, J. A. I.; Jeandel, C.; Leinfelder, R.; McNeill, J. R.; Odada, E.; Oreskes, N.; Price, S. J.; Revkin, A.; Steffen, W.; Summerhayes, C.; Vidas, D.; Wing, S.; Wolfe, A. P. Scale and diversity of the physical technosphere: a geological perspective. The Anthropocene Review 2017, 4, 9. [CrossRef]

27 Um glossário para o Antropoceno. O Correio da Unesco 2018, 2, 28. [Link]

${ }^{28}$ Silva, C. M.; Arbilla, G. Antropoceno: Os Desafios de um Novo Mundo. Revista Virtual de Química 2018, 10, 1619. [CrossRef]

${ }^{29}$ Luberti, G. M. Computation of modern anthropogenic-deposit thicknesses in urban areas: A case study in Rome, Italy. The Anthropocene Review 2018, 5, 2. [CrossRef]

${ }^{30}$ Dodson, J. R.; Hunt, A. J.; Parker, H. L.; Yang, Y.; Clark, J. H. Elemental sustainability: Towards the total recovery of scarce metals. Chemical Engineering and Processing: Process Intensification 2012, 51, 69. [CrossRef]

${ }^{31}$ Xavier, L. H.; Lins, F. A. F.; Nascimento, H. F. F.; Bellan, I. O.; Ribeiro, F.; Caldas, M. B.; Silva, L. O. S.; Zomer, B.; Araujo, R. A.; Filho, O. O. D.; Reinol, P. C.; Fagundes, R. L.; Gusmão, A. C. F.; Manual para a destinação de resíduos eletroeletrônicos: orientação ao cidadão sobre como dispor adequadamente os resíduos eletroeletrônicos na cidade do Rio de Janeiro, 1a ed., Centro de Tecnologia Mineral: Rio de Janeiro, 2017. [Link]

${ }^{32}$ Oguchi, M.; Sakanakura, H.; Terazono, A.; Takigami, H. Fate of metals contained in waste electrical and electronic equipment in a municipal waste treatment process. Waste Management 2012, 32, 96. [CrossRef]
${ }^{33}$ Lu, X.; Nakajima, K.; Sakanakura, H.; Matsubae, K.; Bai, H.; Nagasaka, T. Thermodynamic estimation of minor element distribution between immiscible liquids in $\mathrm{Fe}-$ Cu-based metal phase generated in melting treatment of municipal solid wastes. Waste Management 2012, 32, 1148. [CrossRef]

${ }^{34}$ Ongondo, F. O.; Williams, I. D.; Cherrett, T. J. How are WEEE doing? A global review of the management of electrical and electronic wastes. Waste Management 2011, 31, 714. [CrossRef]

${ }^{35}$ Política Nacional de Resíduos Sólidos, Lei 12305, de 02/08/2010, Brasília, 2010. [Link]

${ }^{36}$ Caracterização gravimétrica e microbiológica dos resíduos sólidos do município do Rio de Janeiro, Centro de Informações Técnicas da COMLURB: Rio de Janeiro, 2012.

37 Saphores, J. D. M.; Ogunseita, O. A.; Shapiro, A. A. Willingness to engage in a proenvironmental behavior: An analysis of ewaste recycling based on a national survey of U.S. households. Resources, Conservation and Recycling 2012, 60, 49. [CrossRef]

${ }^{38}$ Programa Ambiental da Organização das Nações Unidas (UNEP); Convenção de Basileia sobre o Controle de Movimentos Transfronteiriços de Resíduos Perigosos e Sua Eliminação, Organização das Nações Unidas: Genebra, 2014. [Link]

39 Oliveira, C. R.; Bernardes, A. M.; Gerbase, A. E. Collection and recycling of electronic scrap: A worldwide overview and comparison with the Brazilian situation. Waste Management 2012, 32, 1592. [CrossRef]

${ }^{40}$ Kahhat, R.; Williams, E. Materials flow analysis of e-waste: Domestic flows and exports of used computers from the United States. Resources, Conservation and Recycling 2012, 67, 67. [CrossRef]

${ }^{41}$ Man, M.; Naidu, R.; Wong, M. H. Persistent toxic substances released from uncontrolled e-waste recycling and actions for the future. Science of the Total Environment 2012, 463, 1133. [CrossRef] 
${ }^{42}$ Kavousi M.; Sattari A.; Alamdari E. K.; Firoz $S$. Selective separation of copper over solder alloy from waste printed circuit boards leach solution. Waste Management 2017, 60, 636. [CrossRef]

${ }^{43} \mathrm{Lu}, \mathrm{Y}$.; Xu, Z. Precious metals recovery from waste printed circuit boards: A review for current status and perspective. Resources, Conservation and Recycling 2016, 113, 28. [CrossRef]

${ }^{44}$ Kaya, M. Recovery of metals and nonmetals from electronic waste by physical and chemical recycling processes. Waste Management 2016, 57, 64. [CrossRef]

${ }^{45} \mathrm{He}$ J.; Duan, C. Recovery of metallic concentrations from waste printed circuit boards via reverse floatation. Waste Management 2017, 60, 618. [CrossRef]

${ }^{46}$ Zhang L.; Xu, Z. A review of current progress of recycling technologies for metals from waste electrical and electronic equipment. Journal of Cleaner Production 2016, 127, 19. [CrossRef]

${ }^{47}$ Lewis, S. L.; Maslin, M. A. Defining the Anthropocene. Nature 2015, 519, 171. [CrossRef]

${ }^{48}$ Ikhlayel, M. Environmental impacts and benefits of state-of-the-art technologies for Ewaste management. Waste Management 2017, 68, 458. [CrossRef]

${ }^{49}$ Song, Q.; Wang. Z.; Li, J.; Zeng, X. Life cycle assessment of TV sets in China: A case study of the impacts of CRT monitors. Waste Management 2012, 32, 1926. [CrossRef]

${ }^{50}$ Zhou, X.; Guo, J.; Lin, K.; Huang, K.; Deng, J. Leaching characteristics of heavy metals and brominated flame retardants from waste printed circuit boards. Journal of Hazardous Materials 2013, 246-247, 96. [CrossRef]

${ }^{51}$ Zhang, C. C.; Zhang, F. S. Removal of brominated flame retardant from electrical and electronic waste plastic by solvothermal technique. Journal of Hazardous Materials 2012, 221-222, 193. [CrossRef]

52 Habib, M.; Miles, N. J.; Hall, P. Recovering metallic fractions from waste electrical and electronic equipment by a novel vibration system. Waste Management 2013, 33, 722. [CrossRef]

53 Åkesson, A. Cadmium Exposure in the Environment: Renal Effects and the Benchmark Dose. Encyclopedia of Environmental Health 2011, 465. [CrossRef]

${ }^{54}$ Järup, L.; Åkesson, A. Current status of cadmium as an environmental health problem. Toxicology and Applied Pharmacology 2009, 238, 201. [CrossRef]

${ }^{55}$ Rolison, J. M.; Landing, W. M.; Luke, W.; Cohen, M.; Salters V. J. M. Isotopic composition of species-specific atmospheric $\mathrm{Hg}$ in a coastal environment. Chemical Geology 2013, 336, 37. [CrossRef]

${ }^{56}$ Dhal, B.; Thatoi, H. N.; Das, N. N.; Pandey, B. D. Chemical and microbial remediation of hexavalent chromium from contaminated soil and mining/metallurgical solid waste: A review. Journal of Hazardous Materials 2013, 250-251, 272. [CrossRef]

${ }^{57}$ Hua, L.; Chan, Y. C.; Wu, Y. P.; Wu, B. Y. The determination of hexavalent chromium $\left(\mathrm{Cr}^{6+}\right)$ in electronic and electrical components and products to comply with RoHS regulations. Journal of Hazardous Materials 2009, 163, 1360. [CrossRef]

${ }^{58}$ Alabi, O. A.; Bakare, A. A.; Xu, X.; Li, B.; Zhang, Y.; Huo, X. Comparative evaluation of environmental contamination and DNA damage induced by electronic-waste in Nigeria and China. Science of the Total Environment 2012, 423, 62. [CrossRef]

${ }^{59} \mathrm{Ni}$, M.; Xiao, H.; Chi, Y.; Yan, J.; Buekens, A.; Jin, Y.; Lu, S. Combustion and inorganic bromine emission of waste printed circuit boards in a high temperature furnace. Waste Management 2012, 32, 568. [CrossRef]

${ }^{60}$ Guan, J.; Wang, J.; Min, X.; Wu, W. The Products Characteristics of Calcium-basic Compounds Pyrolysis with Waste Printed Circuit Boards (PCB). Procedia Environmental Sciences 2012, 16, 461. [CrossRef]

${ }^{61}$ Zhong, Y.; Peng, P.; Huang, W. Transformation of tetrabromobisphenol $A$ in the presence of different solvents and metals. Chemosphere 2012, 87, 1141. [CrossRef] 
${ }^{62}$ Li, R. C.; Tee, T. J. C. A Reverse Logistics Model For Recovery Options Of E-waste Considering the Integration of the Formal and Informal Waste Sectors. Procedia Social and Behavioral Sciences 2012, 40, 788. [CrossRef]

${ }^{63}$ Lee, C.; Chen, P.; Ma, H. Direct and indirect lead-containing waste discharge in the electrical and electronic supply chain. Resources, Conservation and Recycling 2012, 68, 29. [CrossRef]

${ }^{64}$ Lairaksa, N.; Moon, A. R.; Makul, N. Utilization of cathode ray tube waste: Encapsulation of PbO-containing funnel glass in Portland cement clinker. Journal of Environmental Management 2013, 117, 180. [CrossRef]

${ }^{65}$ Ling, T. C.; Poon, C. S. A comparative study on the feasible use of recycled beverage and CRT funnel glass as fine aggregate in cement mortar. Journal of Cleaner Production 2012 29-30, 46. [CrossRef]

${ }^{66}$ Ghazi, A. M.; Millette, J. R. Lead. In Environmental Forensics. Contaminant Specific Guide; Morrison, R. D., Murphy, B. L. eds.; Academic Press: Burlington, 2006, cap. 4.

${ }^{67}$ Xie, F.; Liu, L.; Li, J. Recycling of Leaded Glass: Scrap Cathode Ray Glass and Fluorescent Lamp Glass. Procedia Environmental Sciences 2012, 16, 585. [CrossRef]

${ }^{68}$ Milovantseva, N.; Saphores, J. D. Time bomb or hidden treasure? Characteristics of junk TVs and of the US households who store them. Waste Management 2013, 33, 519. [CrossRef]

${ }^{69} \mathrm{Niu}, \mathrm{R} . ;$ Wang, Z.; Song, Q.; Li, J. LCA of Scrap CRT Display at Various Scenarios of Treatment. Procedia Environmental Sciences 2012, 16, 576. [CrossRef]

${ }^{70}$ Xiu F. R.; Weng H.; Qi Y.; Yu G.; Zhang Z.; Zhang F. S.; Chen W. A novel recovery method of copper from waste printed circuit boards by supercritical methanol process: Preparation of ultrafine copper materials. Waste Management 2017, 60, 643. [CrossRef]
${ }^{71}$ Diamond, M. L. Toxic chemicals as enablers and poisoners of the technosphere. The Anthropocene Review 2017, 4, 72. [CrossRef]

72 Martinho, G.; Pires, A; Saraiva, L.; Ribeiro, R. Composition of plastics from waste electrical and electronic equipment (WEEE) by direct sampling. Waste Management 2012, 32, 1213. [CrossRef]

${ }^{73}$ Fujimori, T.; Takigami, H.; Agusa, T.; Eguchi, A.; Bekki, K.; Yoshida, A.; Terazono, A.; Ballesteros Jr., F. C. Impact of metals in surface matrices from formal and informal electronicwaste recycling around Metro Manila, the Philippines, and intra-Asian comparison. Journal of Hazardous Materials 2012, 221222, 139. [CrossRef]

${ }^{74}$ Stenvall, E.; Tostar, S.; Boldizar, A.; Foreman, M. R. St. J.; Möller, K. An analysis of the composition and metal contamination of plastics from waste electrical and electronic equipment (WEEE). Waste Management 2013, 33, 915. [CrossRef]

${ }^{75}$ Garcia-Pérez, J.; Navarro, P. F.; Castello, A.; Cima, M. F. L.; Ramis, R.; Boldo, E.; Abente, G. L. Cancer mortality in towns in the vicinity of incinerators and installations for the recovery or disposal of hazardous waste. Environment International 2013, 51, 31. [CrossRef]

${ }^{76}$ Xu, X.; Yang, H.; Chen, A.; Zhou, Y.; Wu, K.; Liu, J.; Zhang, Y.; Huo, X. Birth outcomes related to informal e-waste recycling in Guiyu, China. Reproductive Toxicology 2012, 33, 94. [CrossRef]

${ }^{77}$ Chan, J. K. Y.; Wong, M. H. A review of environmental fate, body burdens, and human health risk assessment of PCDD/Fs at two typical electronic waste recycling sites in China. Science of the Total Environment 2013, 463-464, 1111. [CrossRef]

${ }^{78}$ Wei, L.; Liu, Y. Present Status of e-waste Disposal and Recycling in China. Procedia Environmental Sciences 2012, 16, 506. [CrossRef]

${ }^{79} \mathrm{Ni}, \mathrm{K} . ;$ Lu, Y.; Wang, T.; Shi, Y.; Kannan, K.; Xu, L.; Li, Q.; Liu, S. Polybrominated diphenyl ethers (PBDEs) in China: Policies and recommendations for sound management of 
plastics from electronic wastes. Journal of Environmental Management 2013, 115, 114. [CrossRef]

${ }^{80}$ Zhang, S.; Yoshikawa, K.; Nakagome, H.; Kamo, T. Kinetics of the steam gasification of a phenolic circuit board in the presence of carbonates. Applied Energy 2013, 101, 815. [CrossRef]

${ }^{81}$ Zhou, Y.; Qiu, K. A new technology for recycling materials from waste printed circuit boards. Journal of Hazardous Materials 2010, 175, 823. [CrossRef]

82 Oguchi, D.; Sakanakura, H.; Terazono, A. Toxic metals in WEEE: Characterization and substance flow analysis in waste treatment processes. Science of the total Environment 2013, 463-464, 1124. [CrossRef]

${ }^{83}$ Xu, Q.; Li, G.; He, W.; Huang, J.; Shi, X. Cathode ray tube (CRT) recycling: Current capabilities in China and research progress. Waste Management 2012, 32, 1566. [CrossRef]

${ }^{84}$ Meyer, P. A.; McGeehin, M. A.; Falk, H. A global approach to childhood lead poisoning prevention. International Journal of Hygiene and Environmental Health 2003, 206, 363. [CrossRef]

${ }^{85}$ Gurer-Orhan, H.; Sabır, H. U.; Özgüneş, H. Correlation between clinical indicators of lead poisoning and oxidative stress parameters in controls and lead-exposed workers. Toxicology 2004, 195, 147. [CrossRef]

${ }^{86}$ Moura, F. P.; Oliveira, R. S.; Afonso, J. C.; Vianna, C. A.; Manotvano, J. L. Processamento de cartuchos de impressoras de jato de tinta: um exemplo de gestão de produto pósconsumo. Química Nova 2012, 35, 1271. [CrossRef]

${ }^{87} \mathrm{O}$ mercado de cartuchos remanufaturados no Brasil. Revista Exame 2016, 1117, 32.

${ }^{88}$ Dindarian, A.; Gibson, A. A. P.; Frota-Neto, J. $Q$. Electronic product returns and potential reuse opportunities: a microwave case study in the United Kingdom. Journal of Cleaner Production 2012, 32, 22. [CrossRef]

${ }^{89}$ Queiruga, D.; Benito, J. G.; Lannelongue, G. Evolution of the electronic waste management system in Spain. Journal of Cleaner Production 2012, 24, 56. [CrossRef]

${ }^{90}$ Torretta, V.; Ragazzi, M.; Istrate, I. A.; Rada, E.C. Management of waste electrical and electronic equipment in two EU countries: A comparison. Waste Management 2013, 33, 117. [CrossRef]

${ }^{91}$ Lau, W. K. Y.; Chung, S. S.; Zhang, C. A material flow analysis on current electrical and electronic waste disposal from Hong Kong households. Waste Management 2013, 33, 714. [CrossRef]

${ }^{92}$ Chen, C.; Zhu, J.; Yu, J. Y.; Noori, H. A new methodology for evaluating sustainable product design performance with two-stage network data envelopment analysis. European Journal of Operational Research 2012, 221, 348. [CrossRef]

${ }^{93}$ Garechana, G.; Rio, R.; Cilleruelo, E.; Gavilanes, J. Tracking the evolution of waste recycling research using overlay maps of science. Waste Management 2012, 32, 1069. [CrossRef]

${ }^{94}$ Ravi, V. Evaluating overall quality of recycling of e-waste from end-of-life computers. Journal of Cleaner Production, 2012, 20, 145. [CrossRef]

${ }^{95}$ Ongondo, F. O.; Williams, I. D. Mobile phone collection, reuse and recycling in the UK. Waste Management 2011, 31, 1307. [CrossRef]

${ }^{96}$ Chi, X.; Porte, M. S.; Wang, M. Y. L.; Reuter, M. A. Informal electronic waste recycling: $A$ sector review with special focus on China. Waste Management 2011, 31, 731. [CrossRef]

97 Mazon, M. T.; Azevedo, A. M. M.; Pereira, N. M.; Silveira, M. A. Does Environmental Regulation Foster the Diffusion of Collaborative Innovations? A Study on Electronics Waste Regulation on Brazil. Procedia Social and Behavioral Sciences 2012, 52, 259. [CrossRef]

${ }^{98}$ Sthiannopkao, S.; Wong, M. H. Handling ewaste in developed and developing countries: Initiatives, practices, and consequences. Science of the Total Environment 2013, 463464, 1147. [CrossRef] 
${ }^{99}$ Wang, F.; Huisman, J.; Meskers, C.E.M.; Schluep, M.; Stevels, A.; Hageluken, C. The Best-of-2-Worlds philosophy: Developing local dismantling and global infrastructure network for sustainable e-waste treatment in emerging economies. Waste Management 2012, 32, 2134. [CrossRef]

100 Araújo, M. G.; Magrini, A.; Mahler, C. F.; Bilitewski, B. A model for estimation of potential generation of waste electrical and electronic equipment in Brazil. Waste Management 2012, 32, 335. [CrossRef]

101 Decreto 7404, de 23/12/2010, Brasília, 2010. [Link]

102 Souza, R. G.; Clímaco, J. C. N.; Sant'Anna, A. P.; Rocha, T. B; Valle, R. A. B.; Quelhas, O. L. G. Sustainability assessment and prioritisation of e-waste management options in Brazil. Waste Management 2016, 57, 46. [CrossRef]

${ }^{103}$ Scur, G.; Barbosa, M. E. Green supply chain management practices: Multiple case studies in the Brazilian home appliance industry. Journal of Cleaner Production 2017, 141, 1293. [CrossRef]

104 Decreto 9177, de 23/10/2017, Brasília, 2017. [Link]

105 Caiado, N.; Guarnieri, P.; Xavier, L. H.; Chaves, G. L. D. A characterization of the Brazilian market of reverse logistic credits (RLC) and an analogy with the existing carbon credit market. Resources, Conservation and Recycling 2017, 118, 47. [CrossRef]

106 Echegaray, F.; Hansstein, F. V. Assessing the intention-behavior gap in electronic waste recycling: the case of Brazil. Journal of Cleaner Production 2017, 142, 180. [CrossRef]

107 Dias, P.; Machado, A.; Huda, N.; Bernardes, A. M. Waste electric and electronic equipment (WEEE) management: A study on the Brazilian recycling routes. Journal of Cleaner Production 2018, 174, 7. [CrossRef]

108 Kasper, A. C.; Berselli, G. B. T.; Freitas, B. D.; Tenório, J. A. S.; Bernardes, A. M.; Veit, H. M. Printed wiring boards for mobile phones: Characterization and recycling of copper.
Waste Management 2011, 31, 2536. [CrossRef]

${ }^{109}$ Quintanilha, L. A gestão sustentável de resíduo eletroeletrônico. Revista Meio Ambiente Industrial 2009, 14, 24.

${ }^{110}$ Guarnieri, P.; Silva, L.C.; Levino, N.A. Analysis of electronic waste reverse logistics decisions using Strategic Options Development Analysis methodology: A Brazilian case. Journal of Cleaner Production 2016, 133, 1105. [CrossRef]

${ }^{111}$ Gutberlet, J. Cooperative urban mining in Brazil: Collective practices in selective household waste collection and recycling. Waste Management 2015, 45, 22. [CrossRef]

112 Fan, S. K. S.; Fan, C.; Yang, J. H.; Liu, K. F. R. Disassembly and recycling cost analysis of waste notebook and the efficiency improvement by re-design process. Journal of Cleaner Production 2013, 39, 209. [CrossRef]

113 Achillas, C.; Aidonis, D.; Vlachokostas, C.; Karagiannidis, A.; Moussiopoulos, N.; Loulos, $\mathrm{V}$. Depth of manual dismantling analysis: $A$ cost-benefit approach. Waste Management 2013, 33, 948. [CrossRef]

114 Oliveira, R. S.; Gomes, E. S.; Afonso, J. C. O lixo eletroeletrônico: uma abordagem para o ensino fundamental e médio. Química Nova na Escola 2010, 32, 240. [Link]

115 Norma Brasileira 16156; Resíduos de equipamentos eletroeletrônicos - Requisitos para atividade de manufatura reversa. Associação Brasileira de Normas Técnicas: Rio de Janeiro, 2013.

116 Norma Brasileira 10004; Resíduos Sólidos Classificação. Associação Brasileira de Normas Técnicas: Rio de Janeiro, 2004.

117 Resolução 401, de 04/11/2008, Ministério do Meio Ambiente, Diário Oficial da União, 05/11/2008, Brasília, 2008. [Link]

118 Resolução 264, de 26/08/1999, Ministério do Meio Ambiente, Diário Oficial da União, 20/03/2000, Brasília, 2000. [Link]

119 Zeng, X.; Zheng, L.; Xie, H.; Lu, B.; Xia, K.; Chao, K.; Li, W.; Yang, J.; Lin, S.; Li, J. Current 
Status and Future Perspective of Waste Printed Circuit Boards Recycling. Procedia Environmental Sciences 2012, 16, 590. [CrossRef]

${ }^{120}$ Yamane, L. H.; Moraes, V. T.; Espinosa, D. C. R.; Tenório, J. A. S. Recycling of WEEE: Characterization of spent printed circuit boards from mobile phones and computers.

Waste Management 2011, 31, 2553. [CrossRef]

${ }^{121}$ Camelino, S.; Raoa, J; Padilla, R. L.; Lucci, R. Initial studies about gold leaching from printed circuit boards (PCB's) of waste cell phones. Procedia Materials Science 2015, 9, 105. [CrossRef]

122 Gold Denad Trends - Full Year 2013. The World Gold Council: London, 2013. [Link]

${ }^{123}$ Ghosh, B.; Ghosh, M. K.; Parhi P.; Mukherjee, P. S.; Mishra, B. K. Waste Printed Circuit Boards recycling: an extensive assessment of current status. Journal of Cleaner Production 2015, 94, 5. [CrossRef]

124 Petter, P. M. H.; Veit, H. M.; Bernardes, A. $M$. Evaluation of gold and silver leaching from printed circuit board of cellphones. Waste Management 2014, 34, 475. [CrossRef]

${ }^{125}$ Holgersson, S.; Steenari, B. M.; Björkman, M.; Cullbrand, K. Analysis of the metal content of small-size Waste Electric and Electronic Equipment (WEEE) printed circuit boards part 1: Internet routers, mobile phones and smartphones. Resources, Conservation and Recycling 2018, 133, 300. [CrossRef]

${ }^{126}$ Riedewald, F.; Gallagher, M. S. Novel waste printed circuit board recycling process with molten salt. MethodsX 2015, 2, 100. [CrossRef]

${ }^{127}$ Zhu, P.; Chen, Y.; Wang, L. Y.; Zhou, M. Treatment of waste printed circuit board by green solvent using ionic liquid. Waste Management 2012, 32, 1914. [CrossRef]

128 Tuncuk, A.; Stazi, V.; Akcil, A.; Yazici, E. Y.; Deveci, $\mathrm{H}$. Aqueous metal recovery techniques from e-scrap: Hydrometallurgy in recycling. Minerals Engineering 2012, 25, 28. [CrossRef]

${ }^{129}$ Rath, S.S.; Nayak, P.; Mukherjee, P.S.; Chaudhury, G. R.; Mishra, B. K. Treatment of electronic waste to recover metal values using thermal plasma coupled with acid leaching $-A$ response surface modeling approach. Waste Management 2012, 32, 575. [CrossRef]

${ }^{130}$ Rocchetti L.; Amato A.; Beolchini F. Printed circuit board recycling: A patent review. Journal of Cleaner Production 2018, 178, 814. [CrossRef]

${ }^{131}$ Kumar A.; Holuszko M.; Espinosa D. C. R. Ewaste: An overview on generation, collection, legislation and recycling practices. Resources, Conservation and Recycling 2017, 122, 32. [CrossRef]

132 Menad, N.; Guignot, S.; van Houwelingen, J. A. New characterisation method of electrical and electronic equipment wastes (WEEE). Waste Management 2013, 33, 706. [CrossRef] 133 Joda, N. N.; Rashchi, F. Recovery of ultra fine grained silver and copper from PC board scraps. Separation and Purification Technology 2012, 92, 36. [CrossRef]

${ }^{134}$ Ling, T. C.; Poon, C. S. Feasible use of recycled CRT funnel glass as heavyweight fine aggregate in barite concrete. Journal of Cleaner Production 2012, 33, 42. [CrossRef]

${ }^{135}$ Chen, Y.; Li, J.; Chen, L.; Chen, S.; Diao, W. Brominated Flame Retardants (BFRs) in Waste Electrical and Electronic Equipment (WEEE) Plastics and Printed Circuit Boards (PCBs). Procedia Environmental Sciences 2012, 16, 552. [CrossRef]

${ }^{136}$ Wei, B.; Li, J.; Xie, H.; Liu, L.; Dong, Q. Progress in Research of Comprehensive Utilization of Nonmetallic Materials from Waste Printed Circuit Boards. Procedia Environmental Sciences 2012, 16, 500. [CrossRef]

${ }^{137}$ Wang, Y.; Zhang, F. S. Degradation of brominated flame retardant in computer housing plastic by supercritical fluids. Journal of Hazardous Materials 2012, 205-206, 156. [CrossRef]

${ }^{138}$ Terakado, O.; Ohhashi, R.; Hirasawa, M. Bromine fixation by metal oxide in pyrolysis of printed circuit board containing brominated flame retardant. Journal of Analytical and Applied Pyrolysis 2013, 103, 216. [CrossRef] 
${ }^{139}$ Sahajwalla, V., Gaikwad, V. The present and future of e-waste plastics recycling. Current Opinion in Green and Sustainable Chemistry 2018, 13, 102. [CrossRef]

${ }^{140}$ Richard, G. M.; Mario, M.; Javier, T.; Susana, T. Optimization of the recovery of plastics for recycling by density media separation cyclones. Resources, Conservation and Recycling 2011, 55, 472. [CrossRef]

${ }^{141}$ Norma Brasileira 13230; Embalagens e acondicionamento plásticos recicláveis: identificação e simbologia. Associação Brasileira de Normas Técnicas: Rio de Janeiro, 2008.

142 Lee, M. J.; Rahimifard, S. A novel separation process for recycling of post-consumer products. CIRP Annals 2012, 61, 35. [CrossRef]

${ }^{143}$ Acomb, J. C.; Nahil, M. A.; Williams, P. T. Thermal processing of plastics from waste electrical and electronic equipment for hydrogen production. Journal of Analytical and Applied Pyrolysis 2013, 103, 320. [CrossRef]

${ }^{144}$ Ortuño, N.; Moltó, J.; Egea, S.; Font, R.; Conesa, J. A. Thermogravimetric study of the decomposition of printed circuit boards from mobile phones. Journal of Analytical and Applied Pyrolysis 2013, 103, 189. [CrossRef]

${ }^{145}$ Andersson, M.; Wedel, M. K.; Forsgren, C.; Christéen, J. Microwave assisted pyrolysis of residual fractions of waste electrical and electronics equipment. Minerals Engineering 2012, 29, 105. [CrossRef]

${ }^{146}$ Bhat, V.; Rao, P.; Patil, Y. Development of an integrated model to recover precious metals from electronic scrap - a novel strategy for e-waste management. Procedia Social and Behavioral Sciences 2012, 37, 397. [CrossRef]

${ }^{147}$ Cui, J.; Zhang, L. 2008. Metallurgical recovery of metals from electronic waste: a review. Journal of Hazardous Materials 2008, 158, 228. [CrossRef]

${ }^{148}$ Charles, R. G.; Douglas, P.; Hallin, I. L.; Matthews, I.; Liversage, $G$. An investigation of trends in precious metal and copper content of RAM modules in WEEE: Implications for long term recycling potential. Waste Management 2017, 60, 505. [CrossRef]

${ }^{149}$ Eygen, E. V.; Meester, S. D.; Tran, H. P.; Dewulf, J. Resource savings by urban mining: The case of desktop and laptop computers in Belgium. Resources, Conservation and Recycling 2016, 107, 53. [CrossRef]

${ }^{150}$ Cui, H.; Anderson, C. G. Literature review of hydrometallurgical recycling of printed circuirt boards (PCBs). Journal of Advanced Chemical Engineering 2016, 6, 142. [Link]

${ }^{151}$ Sheng, P. P.; Etsell, T. H. Recovery of gold from computer circuit board scrap using aqua regia. Waste Management \& Research 2007, 25, 380. [Link]

152 Raele M. P.; Pretto L. R.; Zezell D. M. Soldering mask laser removal from printed circuit boards aiming copper recycling. Waste Management 2017, 68, 475. [CrossRef]

${ }^{153}$ Wang, X.; Gaustad, G. Prioritizing material recovery for end-of-life printed circuit boards. Waste Management 2012, 32, 1903. [CrossRef]

154 Bigum, M.; Brogaard, L.; Christensen, T. H. Metal recovery from high-grade WEEE: A life cycle assessment. Journal of Hazardous Materials 2012, 207-208, 8. [CrossRef]

155 Yang, T.; Zhu, P.; Liu, W.; Chen, L.; Zhang, D. Recovery of tin from metal powders of waste printed circuit boards. Waste Management 2017, 68, 449. [CrossRef]

156 Yazici, E. Y.; Deveci, H. Extraction of metals from waste printed circuit boards (WPCBs) in $\mathrm{H} 2 \mathrm{SO} 4-\mathrm{CuSO} 4-\mathrm{NaCl}$ solutions. Hydrometallurgy 2013, 139, 30. [CrossRef]

157 Sun, Z. H. I.; Xiao, Y.; Sietsma, J.; Agterhuis, H.; Visser, G.; Yang, Y. Selective copper recovery from complex mixtures of end-of-life electronic products with ammonia-based solution. Hydrometallurgy 2015, 152, 91. [CrossRef]

${ }^{158}$ Buzatu, T.; Popescu, G.; Birolaga, I.; Saceanu, S. Study concerning the recovery of zinc and manganese from spent batteries by hydrometallurgical processes. Waste Management 2013, 33, 699. [CrossRef] 
${ }^{159}$ Ying, L. J.; Li, X. X.; Quan, L. W. Thiourea leaching gold and silver from the printed circuit boards of waste mobile phones. Waste Management 2012, 32, 1209. [CrossRef]

160 Jha, M. K.; Choubey, P. K.; Jha, A. K.; Kumari, A.; Lee, J.; Kurmar, V.; Jeong, J. Leaching studies for tin recovery from waste e-scrap. Waste Management 2012, 32, 1919. [CrossRef]

161 Hilson, G.; Monhemius, A. J. Alternatives to cyanide in the gold mining industry: what prospects for the future. Journal of Cleaner Production 2006, 14, 1158. [CrossRef]

162 Birloaga, I.; Michelis, I.; Ferella, F.; Buzatu, M.; Vegliò, F. Study on the influence of various factors in the hydrometallurgical processing of waste printed circuit boards for copper and gold recovery. Waste Management 2013, 33, 935. [CrossRef]

${ }^{163}$ Syed, S. Recovery of gold from secondary sources - A review. Hydrometallurgy 2012, 115-116, 30. [CrossRef]

164 Gurung, M.; Adhikari, B. B.; Hawakita, H.; Ohto, K.; Inoue, K.; Alam, S. Recovery of gold and silver from spent mobile phones by means of acidothiourea leaching followed by adsorption using biosorbent prepared from persimmon tannin. Hydrometallurgy 2013, 133, 84. [CrossRef]

165 Lee, J. C.; Pandey, B. D. Bio-processing of solid wastes and secondary resources for metal extraction - A review. Waste Management 2012, 32, 3. [CrossRef]

${ }^{166}$ Flandinet, L.; Tedjar, F.; Ghetta, V; Fouletier, J. Metals recovering from waste printed circuit boards (WPCBs) using molten salts. Journal of Hazardous Materials 2012, 213-214, 485. [CrossRef]

${ }^{167}$ Ferella, F.; Michelis, I.; Veglio, F. Process for the recycling of alkaline and zinc-carbon spent batteries. Journal of Power Sources 2008, 183, 805. [CrossRef]

${ }^{168}$ Sayilgan, E.; Kukrer, T.; Civelekoglu, G.; Ferella, F.; Akcil, A.; Veglio, F.; Kitis, M. A review of technologies for the recovery of metals from spent alkaline and zinc-carbon batteries. Hydrometallurgy 2009, 97, 158. [CrossRef]

${ }^{169} \mathrm{Ma}, \mathrm{L}$;; Nie, Z.; Xi, X.; Li, X. Theoretical simulation and experimental study on nickel, cobalt, manganese separation in complexation-precipitation system. Separation and. Purification Technology 2013, 108, 124. [CrossRef]

170 Lacerda, V. G.; Mageste, A. B.; Santos, I. J. B.; Silva, L. H. M.; Silva, M. C. H. Separation of $\mathrm{Cd}$ and $\mathrm{Ni}$ from $\mathrm{Ni}-\mathrm{Cd}$ batteries by an environmentally safe methodology employing aqueous two-phase systems. Journal of Power Sources 2009, 193, 908. [CrossRef]

${ }^{171}$ Sayar, N. A; Filiz, M.; Sayar, A. A. Extraction of $\mathrm{Co}(\mathrm{II})$ and $\mathrm{Ni}(\mathrm{II})$ from concentrated $\mathrm{HCl}$ solutions using Alamine 336. Hydrometallurgy 2009, 96, 148. [CrossRef]

172 Gotfryd, L., Pietek, G. Contaminants of post leaching copper solutions and their behavior during extraction with industrial extractants. Physicochemical Problems of Mineral Processing 2013, 49, 133. [CrossRef]

${ }^{173}$ Qiu, Y.; Yang, L.; Huang, S.; Ji, Z.; Li, Y. The separation and recovery of copper(II), nickel(II), cobalt(II), zinc(II), and cadmium(II) in a sulfate-based solution using a mixture of Versatic 10 acid and Mextral 984H. Chinese Journal of Chemical Engineering 2017, 25, 760. [CrossRef]

${ }^{174}$ Willner, J.; Fornalczky, A.; Saternus, M. Selective recovery of copper from solutions after bioleaching electronic waste. Nova Biotechnologia et Chimica 2015, 14, 32. [CrossRef]

${ }^{175}$ Sole, K. C.; Feather, A. M.; Cole, P. C. Solvent extraction in southern Africa: An update of some recent hydrometallurgical developments. Hydrometallurgy 2005, 78, 52. [CrossRef]

${ }^{176} \mathrm{Lu}$, J.; Dreisinger, D. Solvent extraction of copper from chloride solution I: extraction isotherms. Hydrometallurgy 2013, 137, 13. [CrossRef] 
177 Silvas, F. P. C.; Correa, M. M. J.; Caldas, M. P. K.; Moraes, V. T.; Espinosa, D. C. R.; Tenório, J. A. S. Printed circuit board recycling: Physical processing and copper extraction by selective leaching. Waste Management 2015, 46, 503. [CrossRef]

178 Zhao, H.; Poon, C. S.; Ling, T. C. Properties of mortar prepared with recycled cathode ray tube funnel glass sand at different mineral admixture. Construction and Building Materials 2013, 40, 951. [CrossRef]

179 Oliveira, A. L. B.; Afonso, J. C. Processamento de pigmentos multimetálicos de tubos de raios catódicos. Revista de Química Industrial 2015, 749, 42. [Link]

180 Mueller, J. R.; Boehm, M W.; Drummond, C. Direction of CRT waste glass processing: Electronics recycling industry communication. Waste Management 2012, 32, 1560. [CrossRef]

181 Yao, Z.; Ling, T. C.; Sarker, P. K.; Su, W.; Liu, J.; Wu, W.; Tang, J. Recycling difficult-to-treat e-waste cathode-ray-tube glass as construction and building materials: A critical review. Renewable and Sustainable Energy Reviews 2018, 81, 595. [CrossRef]

182 Lin, E. Y.; Rahmawati, A.; Ko, J. H.; Liu, J. C. Extraction of yttrium and europium from waste cathode-ray tube (CRT) phosphor by subcritical water. Separation and Purification Technology 2018, 192, 166. [CrossRef]

183 Liu, T.; Song, W.; Zou, D.; Li, L. Dynamic mechanical analysis of cement mortar prepared with recycled cathode ray tube (CRT) glass as fine aggregate. Journal of Cleaner Production 2018, 174, 1436. [CrossRef]

${ }^{184} \mathrm{Hu}, \mathrm{B}$.; Hui, W. Lead recovery from waste CRT funnel glass by high-temperature melting process. Journal of Hazardous Materials 2018, 343, 220. [CrossRef]

185 Tsydenova, O.; Bengtsson, M. Chemical hazards associated with treatment of waste electrical and electronic equipment. Waste Management 2011, 31, 45. [CrossRef]

186 Lin, K. L.; Chang, W. K.; Chang, T. C.: Lee, C. $\mathrm{H}$.; Lin, C. H. Recycling thin film transistor liquid crystal display (TFT-LCD) waste glass produced as glass-ceramics. Journal of Cleaner Production 2009, 17, 1499. [CrossRef]

187 Li, J.; Gao, S.; Duan, H.; Liu, L. Recovery of valuable materials from waste liquid crystal display panel. Waste Management 2009, 29, 2033. [CrossRef]

188 Virolainen, S.; Ibana, D.; Paatero, E. Recovery of indium from indium tin oxide by solvent extraction. Hydrometallurgy 2011, 107, 56. [CrossRef]

189 Pereira, E. B.; Suliman, A. L.; Tanabe E. H.; Bertuol, D. A. Recovery of indium from liquid crystal displays of discarded mobile phones using solvent extraction. Minerals Engineering 2018, 119, 67. [CrossRef]

190 Zhang, K.; Wu, Y.; Wang, W.; Li, B.; Zhang, Y.; Zuo, T. Recycling indium from waste LCDs: A review. Resources, Conservation and Recycling 2015, 104A, 276. [CrossRef]

191 Souada, M.; Louage, C.; Doisy, J. Y.; Meunier, L.; Benderrag, A.; Ouddane, B.; Bellayer, S.; Nuns, N.; Traisnel, M.; Maschke, $U$. Extraction of indium-tin oxide from end-oflife LCD panels using ultrasound assisted acid leaching. Ultrasonics-Sonochemistry 2018, 40, 929. [CrossRef]

192 Fang, S.; Yan, W.; Cao, H.; Song, Q.; Zhang, Y.;Sun, Z. Evaluation on end-of-life LEDs by understanding the criticality and recyclability for metals recycling. Journal of Cleaner Production 2018, 182, 624. [CrossRef]

193 Salhofer, S.; Tesar, M. Assessment of removal of components containing hazardous substances from small WEEE in Austria. Journal of Hazardous Materials. 2011, 186, 1481. [CrossRef]

194 Zhang, K.; Li, N.; Wu, Y.; Wang, W.; Li, R.; Zhang, Y. N.; Zuo, T. Recycling of indium from waste LCD: A promising non-crushing leaching with the aid of ultrasonic wave. Waste Management 2017, 64, 236. [CrossRef]

195 Assefi, M.; Maroufi, S.; Nekouei, R. K.; Sahajwalla, V. Selective recovery of indium from scrap LCD panels using macroporous 
resins. Journal of Cleaner Production 2018, 180, 814. [CrossRef]

196 Ferella, F.; Belardi, G.; Marsilii, A.; Michelis, I.; Vegliò, F. Separation and recovery of glass, plastic and indium from spent LCD panels. Waste Management 2017, 60, 569. [CrossRef] 197 Hasegawa, H.; Rahman, I.; Egawa, Y.; Begum, Z. A. Recovery of indium from end-oflife liquid-crystal display panels using aminopolycarboxylate chelants with the aid of mechanochemical treatment. Microchemical Journal 2013, 106, 289. [CrossRef]

198 Wang, X.; Lu, X.; Zhang, S. Study on the waste liquid crystal display treatment: Focus on the resource recovery. Journal of Hazardous Materials 2013, 244-245, 342. [CrossRef]

199 Oliveira Neto, G. C.; Correia, A. J. C.; Schroeder, A. M. Economic and environmental assessment of recycling and reuse of electronic waste: Multiple case studies in Brazil and Switzerland. Resources, Conservation and Recycling 2017, 127, 42. [CrossRef]

200 Ghisolfi, V.; Chaves, G. L. D.; Siman, R. R.; Xavier, L. H. System dynamics applied to closed loop supply chains of desktops and laptops in Brazil: A perspective for social inclusion of waste pickers. Waste Management 2017, 60, 14. [CrossRef]

201 Moura, J. M. B. M.; Pinheiro, I. G.; Lischeski, D.; Valle, J. A. B. Relation of Brazilian institutional users and technical assistances with electronics and their waste: What has changed? Resources, Conservation and Recycling 2017, 127, 68. [CrossRef]

202 Byström, J. Eco efficiency, a path towards integrated resource management. Waste Management, 2012, 32, 797. [CrossRef]

${ }^{203}$ Kuo, T. C. Waste electronics and electrical equipment disassembly and recycling using Petri net analysis: considering the economic value and environmental impacts. Computers and Industrial Engineering 2013, 65, 54. [CrossRef]

${ }^{204}$ Corazza, R. I. Gestão ambiental e mudanças da estrutura organizacional. RAE Eletrônica 2003, 2, 1. [CrossRef]

205 Silva, W. C.; Corrêa, R. S.; Gismonti, P. R.; Afonso, J. C.; Silva, R. S.; Vianna, C. A.; Mantovano, J. L. Recovery of lead and noble metals after processing printed circuit boards from cell phones by leaching with mixtures containing hydrogen fluoride. Química Nova 2018, 41, 1025. [CrossRef]

${ }^{206}$ Silva, W. C.; Corrêa, R. S.; Silva, C. S. M.; Afonso, J. C.; Silva, R. S.; Vianna, C. A.; Mantovano, J. L. Recovery of base metals, silicon and fluoride ions from mobile phone printed circuit boards after leaching with hydrogen fluoride and hydrogen peroxide mixtures. Waste Management 2018, 78, 781. [CrossRef] 